PARÂMETROS genéticos em PRogênIES de MEIOS IRMÃOS

E CLONAIS NUMA POPULACAO DE EUCALYPTUS GRANDIS

(HILL) MAIDEN NA REGião DE TELÊMACO BORBA-PR

\title{
PAULO KIKUTI
}

ENG FLORESTAL

Orientador: Prof.Paulo Y. Kageyama

Dissertação apresentada à Escola Superior de Agricultura "Luiz de Queiroz", da Universidade de São Paulo, para obtenção do tîtulo de Mestre em Ciências Florestais

\author{
PIRACICABA \\ Estado de São Paulo - Brasil \\ MAIO - 1988
}


Kikuti, Paulo

K47p Parâmetros genéticos em progênies de meios irmãos e clonais numa população de Eucalyptus grandis (Hill) Maiden na região de Telêmaco Borba - PR. Piracicaba, 1988.

$119 \mathrm{p}$.

Diss.(Mestre) - ESALQ

Bibliografia.

1. Eucalipto - Melhoramento 2. Eucalipto - Po pulação - Parâmetro genético 3. Genética florestal I. Escola Superior de Agricultura Luiz de Queiroz, Piracicaba

CDD 634.9734: 
PAKÁMETROS GENETICOS EM PROGENIES DE MEIOS IRMAOS

L CLONAIS NUMA POPULAÇAOO DE EUCALYPTUS GRANDIS

( $H \perp L L)$ MAIDEN NA REGIÃO DE TELEMACO BORBA-PR

PAULO KIKUTI

APROVADA EM: 19-08-1988

COMISSAOO JULGADORA:

Prof. Dr. Pauto Yoshio Kageyama ESALQ/USP

Prof. Dr. Märio Ferreira ESALO /USP

Prof. Dr. Roland Vencovsky ESALQ/USP
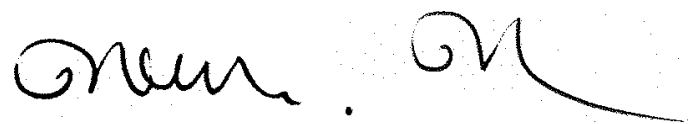

Paulo Yoshio Kageyama ORIENTADOR 
A minha esposa Lucélia

e às minhas filhas

Juliana e Mariana

Ofereço e Dedico 


\section{AGRADECIMENTOS}

Os meus sinceros agradecimentos e em especial deferēncia:

- ao Prof.Dr. Paulo Yoshio Kageyama, pela orientação e incentivo na realização deste trabalho.

- à Indūstria Klabin de Papel e Celulose S.A., em especial ao Dr.Rui Fernando Romero Monteiro e Dr. Raul Mário Speltz, pelo apoio e oportunidade de realização deste trabalho.

- aos amigos e pesquisadores da Klabin, em especial ao Moacyr Fantini Junior, Ivone Satsuki Namikawa e Moacir Marcolin, pelo apoio, troca de in formações e sugestões.

- aos técnicos, em especial ao Braulio Roberto Bahr, Abel Santana, Edmilson Luiz Quadros, Ronaldo de Paula Castanho e Antonio Cesar Benato, pela colaboração na instalação e manutenção do ensaio e na coleta de dados do experimento.

- ao Divonzir Araūjo Carneiro e Jairo Mendes de Matos pela colaboração no processamento dos dados.

- à Symone Borges de 01iveira, pela dedicação no trabalho de datilografia.

- à minha esposa Lucēlia B. Lopes Kikuti, pelo apoio e incentivo constante.

- à todos aqueles que contribuiram direta ou indiretamente para a realização deste trabalho. 


\section{INDICE}

Pāgina

LISTA DE TABELAS $\ldots \ldots \ldots \ldots \ldots \ldots \ldots \ldots \ldots \ldots \ldots \ldots \ldots \ldots \ldots \ldots \ldots \ldots \ldots \ldots$

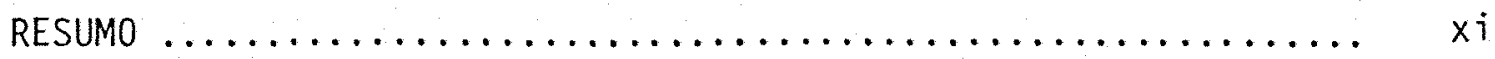

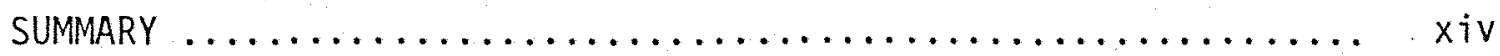

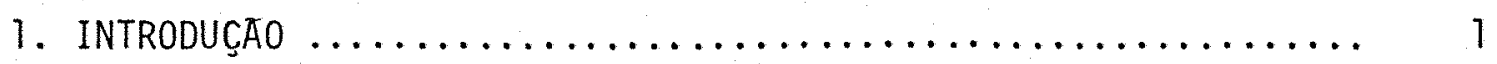

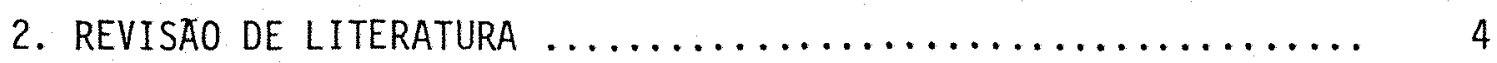

2.1. Métodos de Melhoramento Florestal ............... 4

2.1.1. Melhoramento genético por via sexuada ........ 7

2.1.2. Melhoramento genētico por via assexuada (Propagação vegetativa) $\ldots \ldots \ldots \ldots \ldots \ldots \ldots \ldots . .9$

2.1.3. Desenvolvimento de plantas propagadas vegetativamente em comparação com plantas propagadas por sementes $\ldots \ldots \ldots \ldots \ldots \ldots \ldots \ldots, 12$

2.2. Estimativas de Parāmetros Genéticos ............. 15

2.2.1. Teste de progénies de polinização aberta ...... 23

2.2.2. Teste de progēnie clonal ............... 25

2.3. Estimativas de Herdabilidade no Sentido Restrito e no Sentido Amplo ....................... 28

3. MATERIAL E METODOS $\ldots \ldots \ldots \ldots \ldots \ldots \ldots \ldots \ldots \ldots \ldots \ldots \ldots \ldots \ldots \ldots \ldots \ldots \ldots \ldots \ldots$

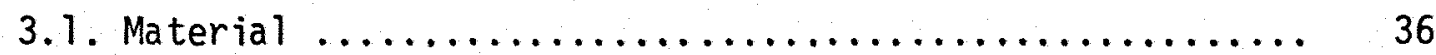

3.1.1. Material genëtico $\ldots \ldots \ldots \ldots \ldots \ldots \ldots \ldots \ldots . . \ldots \ldots$

3.1.2. Descrição do local de instalação do experi-

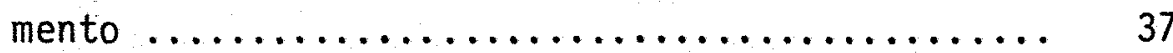

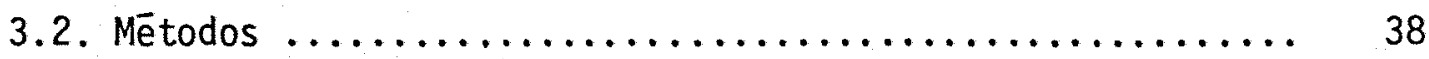

3.2.1. Instalação dos ensaios $\ldots \ldots \ldots \ldots \ldots \ldots \ldots \ldots, 38$ 
Pāgina

3.2.2. Del ineamento experimental $\ldots \ldots \ldots \ldots \ldots \ldots$

3.2.3. Condução do experimento .............. 39

3.2.4. Coleta de dados $\ldots \ldots \ldots \ldots \ldots \ldots \ldots \ldots \ldots \ldots \ldots$

3.2.5. Anāilise estatística e estimação de variāncias genëticas e fenotipicas ............ 40

3.2.6. Anāi ise de variāncia conjunta para mētodos de propagação, envolvendo as ārvores selecionadas e testemunhas sem seleção ...........

3.2.7. Estimativa dos coeficientes de herdabilidade $\left(h^{2}\right)$

3.2.8. Estimativas de progressos genēticos na seleção

4. RESULTADOS E DISCUSSAOO

4.1. Resultados das Anālises de Variāncia Individua is .....

4.2. Resultados das Anālises das Variāncias Conjuntas para as Caracteristicas de Crescimento Envolven-

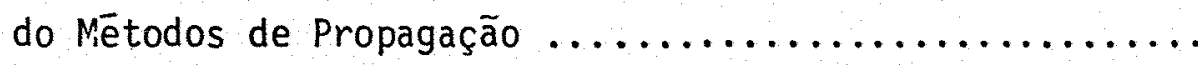

4.3. Estimativa de Parāmetros Genēticos 78

4.3.1. Estimativa de variāncias genéticas e não genēticas para as características altura, DAP e volume cilindrico

4.3.2. Estimativas de herdabilidade

4.3.3. Estimativa de ganho genētico com seleção entre e dentro de progénies para as caracteristicas altura, DAP e volume cilindrico 
1 Coeficientes de herdabilidades no sentido restrito ao nivel de planta individual para diversas carac-

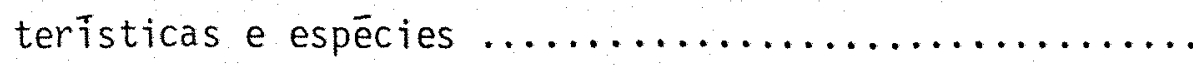

2 Coeficiente de herdabilidade para densidade da madeira, segundo BRITO \& BARRICHELO e FERREIRA (1978)......

3 Coeficientes de herdabilidades para diversas espē-

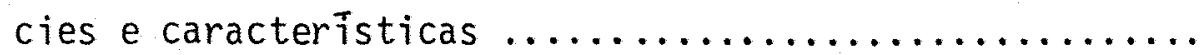

4 Sobrevivência das progēnies aos 30 meses de idade $\ldots . \ldots .52$

5 Resultados das anāilises de variāncia para a carac-

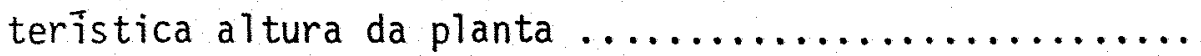

6 Dados comparativos de altura média (m) entre matri zes selecionadas e testemunhas sem seleção para dois métodos de propagação $\ldots \ldots \ldots \ldots \ldots \ldots \ldots \ldots \ldots \ldots, 56$

7 Dados comparativos de altura média (m) entre métodos de propagação (progēnies de meios irmãos e pro gēnies clonais) para matrizes selecionadas e tes-

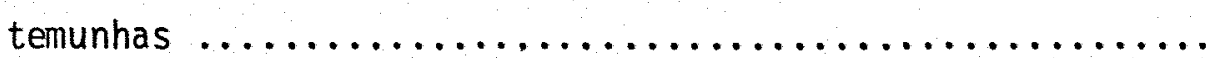

8 Resultados da anālise de variāncia individual para caracteristica DAP $(\mathrm{cm})$, aos 30 meses de idade ....... 60

9 Valores comparativos para diāmetro de plantas (DAP em $\mathrm{cm}$ ) entre matrizes selecionadas e testemunhas para os dois métodos de propagação 
10 Dados comparativos de diāmetro (DAP em $\mathrm{cm}$ ) entre métodos de propagação (progénies de meios irmãos e progēnies clonais) para matrizes selecionadas e tes temunhas

11 Resultados das anālises de variância individual em látice, para a caracteristica volume cilindrico

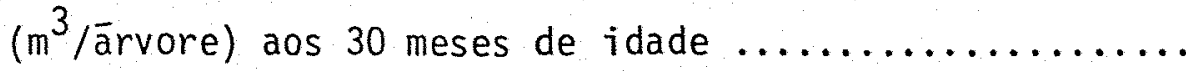

12 Valores comparativos de volume cilindrico $\left(\mathrm{m}^{3} /\right.$ ărvo re) entre matrizes selecionadas e testemunhas e entre métodos de propagação, aos 30 meses de idade ..... 66

13 Valores de $F$ e coeficientes de variação experimental ( CV \%) nas anālises de variāncia conjunta para altura, DAP e volume cilindrico envolvendo do is me todos de propagação, aos 30 meses de idade

14 Incremento médio anual (IMA) em volume cilindrico $\left(\mathrm{m}^{3} / \mathrm{ha} / \mathrm{ano}\right)$ aos 30 meses de idade, para progēnies

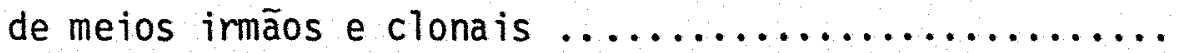

15 Médias ajustadas de altura, DAP e volume cilindrico das 45 matrizes selecionadas aos 30 meses de idade e ordenadas em posições decrescentes .............

16 Estimativa de variāncias genēticas dentro de progènies $\left(\sigma^{2} d\right)$, entre progēnies $\left(\sigma^{2} p\right)$, do erro $\left(\sigma^{2} e\right)$, fenotipica $\left(\sigma^{2} F\right)$ e a relação $\sigma^{2} d / \sigma^{2} p$, para as caracteristicas altura, DAP e volume cilindrico, aos 30 meses de idade 
17 Estimativas das variäncias genéticas não aditivas $\left(\sigma^{2} N A\right)$

em progēnies de meios irmãos para características de crescimento, aos 30 meses de idade .............. 82

18 Coeficiente de variação dentro de progēnies $\left(\mathrm{CV}_{\mathrm{d}} \%\right)$, entre progenies $\left(\mathrm{CV}_{\mathrm{p}} \%\right)$ e fenotipicas $\left(\mathrm{CV}_{\mathrm{F}} \%\right)$ para as caracteristicas estudadas aos 30 meses de idade .........

19 Coeficiente de variação dentro de progēnies para as características altura e DAP nas idades de 12,18 ,

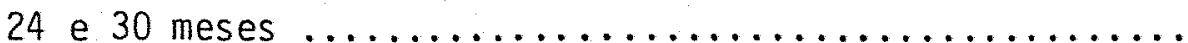

20 Coeficientes de variação genētica entre progēnies $\left(\mathrm{CV}_{\mathrm{p}} \%\right)$, para as caracteristicas altura e DAP aos $12,18,24$ e 30 meses de idade $\ldots \ldots \ldots \ldots \ldots \ldots \ldots \ldots$

21 Coeficiente de variação fenotîpica ( $\mathrm{CV}_{\mathrm{F}} \%$ ) para as características altura da planta e DAP aos 12, 18, 24 e 30 meses de idade

22 Estimativas de coeficientes de herdabilidade ao nivel de plantas individuais ( $h^{2}$ individuais), ao $n \hat{i}-$ vel de mēdias de famillias ( $h^{2}$ médias) e ao nivel de plantas dentro de familias ( $h^{2}$ dentro), no sentido restrito para progēnies de meios irmãos e no senti-

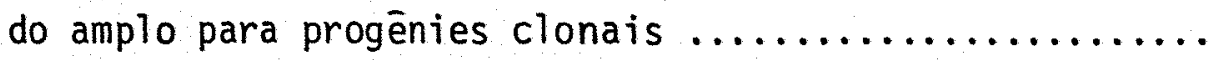

23 Coeficientes de herdabilidade para progénies de meios irmãos (PMI) e para progēnies clonais, para matrizes selecionadas e testemunhas, aos 30 meses

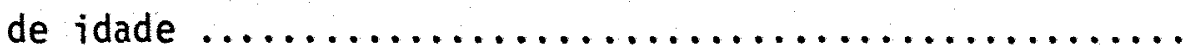


24 Coeficientes de herdabilidade para matrizes selecionadas e testemunhas para progēnies de meios irmãos e clonais, aos 30 meses de idade ..............

25 Estimativa de ganhos genéticos $\left(G_{S} \%\right)$ em progēnies de meios irmãos e em progénies clonais, para as caracteristicas altura, DAP e volume cilindrico ...... 102 
PARĀMETROS GENETICOS EM PROGENIES DE MEIOS IRMAOOS E CLONAIS NUMA POPULACAO DE Eucalyptus grandis (Hi11) MAIDEN NA REGIAO

DE TELEMACO BORBA - PR.

Autor: Paulo Kikuti

Orientador: Prof.Dr. Paulo Yoshio Kageyama

RESUMO

0 desenvolvimento da técnica de propagação vegetativa por estaquia em espécies de Eucalyptus tem possibilitado o plantio de populações melhoradas a curto prazo, representando uma ferramenta importante nos programas de melhoramento florestal.

Este trabalho teve como objetivos estimar os parāmetros genéticos de uma população de Eucalyptus grandis (Hill) Maiden, para características de crescimento, avaliação do potencial genētico de ārvores selecionadas e estimar os qanhos genéticos com a selecão, em dois métodos de propagação.

Foram instalados nas mesmas condições testes de progēnies de meios irmãos e clonais, a partir de 45 ārvores selecionadas e de 36 árvores tomadas ao acaso da população. Os ensaios foram implantados no município de Telémaco Borba-Pr, em maio de 1985, utilizando-se o delineamento experimental em látice triplo 9x9. Foram utilizadas parcelas 1ineares de 10 plantas a um espaçamento de $3,0 \times 3,0 \mathrm{~m}$. 
As avaliações dos testes foram realizadas nas idades de 12, 18, 24 e 30 meses para as características altura e diāmetro, e de 24 e 30 meses para volume cilindrico. Os resultados mostraram uma boa sobre vivēncia nas mudas propagadas por sementes, sendo de $96,5 \%$ para matrizes selecionadas e $97,7 \%$ para testemunhas. Nas progēnies clonais as sobrevivēncias foram de $85,7 \%$ e $79,8 \%$, respectivamente para matrizes selecionadas e testemunhas.

Os valores de $F$ nas anālises de variāncia em látice mostraram variações genēticas significativas para as características altura, DAP e volume cilindrico, tanto entre progēnies de meios irmãos como entre progénies clonais, aos 30 meses de idade.

Para as caracteristicas de crescimento foram detectadas melhores médias nas plantas propagadas por sementes em relação às plantas propagadas por estacas. Essa diferença entre progēnies de meios irmãos e clonais para o volume cilindrico foi de 10,60\% para matrizes selecionadas e de $17,72 \%$ para testemunhas.

A anālise conjunta para os dois métodos de propagação revelou variações genéticas entre progēnies altamente significativas para todas as caracterīsticas. Os efeitos do método de propagação e de interação progēnies $x$ método de propagação tambēm foram altamente significativos. O comportamento diferencial das matrizes frente ao mētodo de propagação sugere a sua utilização para obtenção de materiais especîficos nos programas de melhoramento sexuado ou assexuado. 
Os clones apresentaram um crescimento inicial lento em relação às progēnies de meios irmãos e um al to coeficiente de variação dentro de parcelas $\left(\mathrm{CV}_{\mathrm{d}^{\%}}\right)$ aos 12 meses de idade. Entretanto, nos clones 0 coeficiente de variação dentro de parcelas, nas características estudadas, mostrou tendência de diminuição com a idade, sendo que aos 30 meses apresentaram menores valores em relação às progēnies de meios irmãos. Quanto ao coeficiente de variação entre progênies $\left(C V_{p} \%\right)$, foram detectados menores valores em progēnies de meios irmãos. A relação $\sigma^{2} d / \sigma^{2} p$ mostrou valores altos, acima de 10, confirmando a caracteristica alógama da espécie, enquanto que nas progénies clonais essa relação apresentou valores baixos (entre 1,64 e 3,23), mostrando padrões de plantas de propagação vegetativa.

Detectou-se coeficientes de herdabilidades maiores no sentido amplo (progénies clonais) que no sentido restrito (progênies de meios irmãos), tanto ao nīvel de plantas individuais como ao nīvel de médias de familitias, sendo que as diferenças variaram para cada caracterîstica e em cada material genético (matrizes selecionadas e testemunhas). A estimativa de ganho genético $\left(G_{S} \%\right)$ com a seleção entre progēnies foi maior nos clones do que em progênies de meios irmãos. Entretanto verificou-se que nas progēnies de meios irmãos a possibilidade de se efetuar tambēm a seleção dentro, pode tornar os ganhos prōximos entre os dois métodos de propagação. 


\section{ESTIMATES OF GENETIC PARAMETERS IN HALF-SIBS AND CLONAL \\ PROGENIES ON A Eucalyptus grandis (Hi11) MAIDEN \\ POPULATION IN TELEMACO BORBA, Pr.}

Author: Paulo Kikuti

Adviser: Prof.Dr. Paulo Yoshio Kageyama

SUMMARY

The development of rooting cuttings technics in Eucalyptus species has made improved population establishment possible in a short period of time, being an important tool dealing to breeding programs.

The objectives of this work were to estimate the genetic parameters of Eucalyptus grandis (Hill) Maiden population to evaluate the genetic potential of the selected trees and to estimate genetic gains with selection for the propagation methods used.

Half-sib and clonal progeny tests from 45 selected trees and 36 without selection were established at the same environment condition in Telèmaco Borba, Pr., in May 1985.

Linear plots consisting of 10 plants and the $3,0 \times 3,0 \mathrm{~m}$ spacing were used in triple $9 \times 9$ lattice experimental design.

The evaluation of the trials was conducted at the ages of $12,18,24$ and 30 months, for height and diameter growth. At 24 and 30 months, cylindric volume was also evaluate. 
The results showed better survival rates for seedlings; $96,5 \%$ from the selected trees and $97,7 \%$ from trees without selection compared to cuttings: $85,7 \%$ and $79,8 \%$ from selected and non selected trees, respectively.

At 30 months the $F$ values revealed significant genetic variation for heigh, DBH and cylindric volume characteristics, among half-sibs progenies as well as among clonal progenies.

The best averages for growth characteristics were obtained in plant propagation by seeds compared to rooted cuttings. The difference in cylindric volume growth between half-sib and clonal progenies was $10,60 \%$ for selected trees and $21,44 \%$ for non selected trees.

The joint analysis of variance for propagation methods showed significant genetic variation among progenies for all characteristics studied. Also, the effects of propagation methods and the progeny $x$ propagation method interaction were highly significant. Different pattern of behavior were detected among progenies when propagated by seeds or by cuttings, suggesting the utilization of specific material to sexual or assexual breeding program.

At first, clonal progenies revealed slow development and high coefficient of variation within clones in relation to half-sib progenies. However, the coefficient of variation within the clones showed general decreasing tendency with the age and at 30 months, the plants propagated by cuttings showed lower coefficient of variation within the progenies than those propagated by seeds. 
On the other hand, the coefficient of variation

among progenies were higher for the clones than those for the seedlings.

The relationships between phenotypic variation within progenies and genetic variation among progenies $\left(\sigma^{2} d / \sigma^{2} p\right)$ for half-sib progenies revealed high values (above 10,00), suggesting outbreeding species characteristics while for clonal progenies, the relationship showed low values (between 1,64 to 3,23 ), suggesting vegetative propagation's characteristic.

The broad sense heritability (for clonal*progeny) were greater than the narrow sense heritability (for half-sib progeny) at plant level as well as the average family level and the pattern of difference between of two type of heritability changed among the characteristics studied and for genetic material (selected and without selection trees).

The estimates of genetic gains with selection among progenies showed major values for cuttings (clonal progeny) than those obtained by seedlings (half-sib progeny) for all characteristics. However, because of the possibility to make selection within family on the halfsib progenies, approximately same gains between propagation methods were observed. 
1. INTRODUÇÃO

Introduzido no Brasil, o gēnero Eucalyptus mostrou excelente adaptação e vem sendo largamente utilizado em reflorestamento visando a produção de madeira para diversas finalidades, tais como para serraria, celulose e papel, chapas de fibras, carvão vegetal, lenha, etc.

Dentre as diversas espēcies utilizadas, o Eucalyptus grandis è o mais plantado por apresentar boas características tecnolōgicas e silviculturais como, al to incremento volumétrico, boa forma do tronco, qualidade adequada da madeira em condições ecológicas amplas.

Na região de origem, esta espēcie apresenta uma ampla ārea de ocorrēncia natural. Dentre as procedēncias, a de Coff's Harbour apresentou o melhor desenvolvimento no Estado de São Paulo, originando grandes populações na região de Mogi-Guaçū. A partir de sementes desta população base, foram reflorestadas grandes āreas com esta espēcie na região de Telémaco Borba, Paranā, onde tambēm apresentou excelente adaptação e al ta produtividade de madeira. 
Para fins de melhoramento genētico desta população, foram iniciados trabalhos de seleção de ärvores superiores principalmente quanto a característica de crescimento e forma do tronco.

Por outro 1ado, o desenvolvimento de técnicas de propagação vegetativa por estaquia em espécies de Eucalyptus tem possibilitado o plantio de populaçōes melhoradas a curto prazo, com ganhos bastante ele vados. Assim, esta tēcnica representa um papel importante nos programas de melhoramento, principalmente na utilização de híbridos que apresentaram vigor e boa adaptação local. Este método permite a exploração da variabilidade genética total e consequentemente obter maior progresso com a seleção.

Entretanto, a grande questão é com respeito ao ganho a ser obtido a partir de propagação vegetativa em relação à propagação por sementes, quando se utilizam espēcies puras. Neste caso, a comparação de ganho deve ser feita entre clones selecionados e progēnies obtidas de sementes melhoradas.

As informações genēticas sobre 0 assunto são escassas na literatura, principalmente em Eucalyptus, por ser uma tëcnica de propagação massal relativamente recente.

Este trabalho constitui basicamente da instalação dos testes de progēnies por sementes e por clones provenientes de ärvores selecionadas e de ārvores ao acaso na população de Eucalyptus grandis implantada na região de Telēmaco Borba.

0 ensaio envolvendo progēnies de polinização livre (meios imãos) e progēnies clona is teve os seguintes objetivos: 
a. Avaliar o potencial de crescimento de progēnies de meios irmãos e clonais provenientes de ārvores selecionadas e não selecionadas de uma população de Eucalyptus grandis.

b. Determinar os parâmetros genēticos para progēnies de meios irmãos e clonais, provenientes de ārvores selecionadas e não selecionadas da população. 


\section{REVISÃO DE LITERATURA}

2.1. Métodos de Melhoramento Florestal

0 programa de melhoramento de essências florestais è distinto claramente das plantas agricolas ou horticolas. Nestas plantas, os esforços de melhoramento estão voltados ao desenvolvimento de uma boa variedade, constituĩda de genōtipos mais ou menos uniformes, enquanto que en essēncias florestais, com poucas exceções, esta uniformidade è indesejāvel do ponto de vista de manejo devido ao período de rotação relativamente longo, alta variabilidade das condições do "site" e amplo risco de dano por pragas e doenças.

Os esquemas de melhoramento genético de espécies florestais exōticas, de um modo geral, podem ser resumidos em introdução de espécies, instalação de ensaios de procedencias e seleção dentro de população base (KAGEYAMA, 1980).

Assim, um programa de melhoramento tradicional, conforme BAWA (1976) e WRIGHT (1964), consiste tipicamente de: 
a. seleção de fenōtipos superiores em populações naturais;

b. replicação do fenōtipo selecionado em banco clonal;

c. recombinação de genōtipo atravēs de polinização controlada;

d. instalação de ensaios de progénies.

Estes métodos, segundo KAGEYAMA (1981), baseiam-se principalmente na seleção intensiva de ārvores fenotipicamente superiores, justificados pela existência de uma ampla variabilidade natural ainda a ser explorada nas populações. Esta variabilidade genētica pode ser, basicamente, entre espécies, entre procedēncias de uma mesma espécie e entre ārvores de uma procedēncia.

SHELBOURNE (1969) cita que os melhoristas florestais, para planejarem programas efetivos, devem conhecer uma gama de possiveis mētodos de melhoramento e ter alguns meios de comparação da quantidade de progresso que se pode esperar de cada uma.

Entretanto, hā que considerar que as seleções recorrentes sucessivas, nos programas tradiciona is de melhoramento, com um aumento gradativo da intensidade de seleção, reduzem o tamanho efetivo de indivīduos da população, podendo levar ao estreitamento da base genética e consequentemente ao esgotamento da variabilidade. Ainda nestes programas, a interação genōtipo $\mathrm{Y}$ ambiente ē aproveitada para selecionar genōtipos que respondam favoravelmente a uma ampla gama de condições, mesmo que haja um menor ganho em cada local. 
A estratégia de multipopulações, apresentada por NAMKOONG (1984) diz respeito à existência de vārias populações selecionadas, provenientes da mesma população base original, mantida em separado de certa forma divergentes. Desta forma, a utilização de diferentes sub populações para diferentes situações ecolōgicas e usos finais permite um maior ganho genético por geração. Essa estratēgia mantém a variabilidade potencial da população base inicial, atravēs da possibilidade de cruzamento de multipopulações, ao mesmo tempo que permite o melhoramento contīnuo de cada sub população.

Populações mültiplas são selecionadas como unidade de meThoramento com diversos objetivos fixados. Quanto mais diversos forem os objetivos, maior e mais numerosas devem ser as populações divergentes (NAMKOONG, 1982).

0 programa de melhoramento clāssico baseia-se numa ūnica população base, escolhida em função dos objetivos econōmicos e condições ambientais. Assim, inicialmente seleciona-se a espécie, em seguida a pro cedéncia da mesma espécie e finalmente população dentro da procedéncia, que serā melhorada durante gerações sucessivas, para diversas caracteristicas silviculturais. Em contraste a este programa, a estratégia de multilinhas, conforme CHAPERON (1984), consiste na conservação, a cada estāgio do programa, de diversas espécies, diversas procedēncias ou diversas populações, cada uma selecionada para uma caracterîstica ou ambientes diferentes. A utilização destas populações em cruzamentos complementares, poderā permitir maiores ganhos genéticos que a estratēgia clāssica.

Portanto as vantagens desta estratēgia residem na obtenção 
de ganhos genéticos maiores, particularmente quando as características es tão negativamente correlacionadas e na manutenção da variabilidade genéti ca que pode ser preservada em todos os niveis.

Por outro lado, quando se seleciona uma população de indivĩduos para uma ampla gama de condições, tem-se um menor ganho para cada local e maior restrição na variabilidade para a população (NAMKOONG, 1984).

Tanto na estratégia tradicional como na de multipopulaçōes, distinguem-se 2 métodos principa is de melhoramento: mëtodo baseado na via sexual e método baseado na via assexual. Em ambos os métodos, os ganhos genéticos em cada geração são funções da herdabilidade das caracte rísticas das ārvores, da intensidade de seleção (FERREIRA, 1980) e do nūmero de caracteres sob seleção (QUIJADA, 1980).

\subsubsection{Melhoramento genético por via sexuada}

Conforme FERREIRA (1980), este método baseia-se na produção de sementes utilizando-se a variabilidade genética natural existente entre populações e entre indivĩduos. Neste programa, são instaladas āreas de coleta de sementes, bancos clonais, pomares de sementes clonais ou por mudas e os testes de progēnies.

Assim, as ārvores fenotipicamente superiores são multiplicadas vegetativamente somente para instalação de pomares para produção de sementes de qualidade genética superior. A seleção fenotîpica individual dentro da população base adequada e sua utilização para produção de 
sementes melhoradas através de pomares de sementes, tanto por clones como por mudas, constitui um dos metodos ma is correntes no melhoramento florestal (KAGEYAMA e VENCOVSKY, 1983).

Porēm, neste esquema de seleção è necessāria a obtenção de genōtipos superiores ou indivĩduos que sejam capazes de deixar descendentes tambēm com genōtipos superiores. Conforme VENCOVSKY (1977), em plantas panmíticas onde a multiplicação é feita por cruzamento, o genótipo dos descendentes não depende só do indivĩduo selecionado, mas tambēm do genōtipo daqueles indivīduos com o qual ele foi cruzado. Portanto, o valor genotípico dos genitores nem sempre é reproduzido integralmente nos descendentes.

Desta forma, è necessário o conhecimento do grau de controle genético na manifestação fenotîpica das diversas caracteristicas, para um direcionamento consciente do programa de melhoramento a ser desenvolvido (FONSECA, 1979).

Assim, a informação sobre herdabilidade è necessāria não somente para avaliação dos efeitos no melhoramento, mas também para escoTha do esquema de melhoramento (TODA, 1972, SQUILLACE et alii, 1967). Quan do a herdabilidade de uma caracterîstica é alta, a propagação de indivīduos selecionados em pomares de sementes darā ganho genético correspondente à alta intensidade de seleção. Caso contrārio, quando o valor da herdabilidade è baịo, a alta intensidade de seleção não darā grande progresso nos valores genotípicos das progēnies, enquanto que a seleção de grande nūmero de indivĩduos com baixa intensidade de seleção, seguida de seleção entre famîlias de progēnies darā um progresso mais constante. 
A seleção por famîi ias vem sendo considerada altamente importante para as caracteristicas de baixa herdabilidade, tais como as de difícil avaliação fenotîpica, como as caracteristicas da qualidade da madeira (KAGEYAMA, 1980b).

Em plantios em larga escala, hā três vantagens principais para a reprodução por sementes (LONGMAM, 1976): a) obtenção de grande nümero de plantas quando a espécie é uma boa produtora de sementes, b) as sementes podem ser armazenadas, c) a variação é mantida em gerações sucessivas, embora possa haver sērios problemas de depressão endogâmica quan do as sementes são colhidas de árvores isoladas ou de grupos de ārvores estreitamente aparentadas.

Porēm, a importāncia do melhoramento genético por via sexuada reside na possibilidade de se efetuar a recombinação entre as matrizes e a seleção na nova população, o que permite obter ganhos sucessivos a cada geração, sem redução significativa do tamanho efetîvo populacional.

2.1.2. Melhoramento genētico por via assexuada (Propagação vegetativa)

A propagação vegetativa tem sido utilizada amplamente en melhoramento, segundo QUIJADA (1980b), para estabelecimento de bancos e pomares de sementes clonais, propagação de hỉbridos e, ainda, para propagação de plantas selecionadas em larga escala. 
Vărias finalidades da propagação vegetativa são apresen- tadas por BURDON (1982) num programa de melhoramento, tais como a manutenção de genótipos em arquivo, suprir pomares de sementes clonais, propagação massal de clones selecionados, utilização total dos efeitos dos gens não aditivos e obter informações genéticas. A propagação vegetativa possibilita, ainda, a obtenção de florestas com grande uniformidade no tamanho das ārvores, qualidade e propriedades da madeira (ZOBEL e TALBERT, $1984)$.

0 melhoramento genético por via assexuada em Eucalyptus, conforme FERREIRA (1980), è realizado através de enraizamento de propagulos de árvores selecionadas, na maioria dos casos de híbridos, visando a implantação de testes de progēnies clonais e āreas de multiplicação clo nal, básicos para formação de plantações comerciais.

A implantação de florestas constituĩdas de clones, para muitas espécies florestais incluindo o Eucalyptus spp., foram possiveis pelo desenvolvimento da técnica de propagação por estacas, a um custo com petitivo (ROULAND, 1973). Segundo CHAPERON (1984), a propagação por estaquia geralmente é utilizada para duas diferentes finalidades:

a. como instrumento para melhoramento, possibilitando a conservação genética (banco clonal), instalação de pomar de sementes clonal, estimativa de parâmetros genéticos e pesquisas em fisiologia e patologia;

b. para difusão de progresso genético atravēs de multiplicação massal de famîlias ou indivĩduos superiores. 
Nas plantas que permitem a reprodução vegetativa, os es-quemas mais simples de seleção compreendem apenas a identificação de fenótipos desejāveis. Neste caso, o tipo de genōtipo não influencia no pro cesso de multiplicação, jā que os descendentes terão todos exatamente o mesmo genótipo que aquele selecionado inicialmente (VENCOVSKY, 1977).

Assim, a propagação vegetativa possibilita a exploração de variabilidade genética total e perpetua genōtipos superiores, sem diluir seu potencial genético e também permite uma maior uniformidade nas plantações do que quando se utiliza sementes (THUL IN, 1969).

Desta forma, o que se procura em programas de melhoramento, baseados em métodos assexuados, è a obtenção de ganhos genéticos māximos numa única geração, utilizando todos os nîveis de variabilidade entre espécies e dentro de espécies (FERREIRA, 1980).

Porém, deve-se lembrar que a redução da variabilidade genética por esse método pode limitar os programas de melhoramento a longo prazo, além de elevar o risco de infestação de insetos e doenças em plantações constituīdas por um número limitado de clones.

Entretanto, a propagação vegetativa por estaquia, aplicada na estratégia de multilinhas, conforme CHAPERON (1984), permite maior variabilidade na população, maior flexibilidade no programa de melhoramento e progresso genético mais rápido, alēm de possibilitar um aumento de precisão na seleção de genótipos em teste de progēnies.

Segundo THULIN (1969), o uso de estacas enraizadas ē particularmente útil em melhoramento florestal para caracteristicas de baixa 
herdabilidade, em usos especificos e para maior adaptabilidade ao frio e "sites" nutricionalmente deficientes.

ZOBEL et alii (1983) sugerem a propagação vegetativa através de estacas para Eucalyptus como um método de obtenção de madeira uniforme e de melhor qualidade, através da seleção das melhores ārvores. Segundo os autores, o método proporciona um ganho rāpido comparado à propagação sexuada, mas deve-se levar em consideração o afunilamento de base genética.

Quando a espécie for facilmente propagada vegetativamente, a clonagem torna-se uma medida rotineira. Juntamente com a uniformidade nos clones, a perspectiva mais atraente é o uso total dos efeitos dos genes não aditivos, o qual não é possîvel obter na propagação por sementes (BURDON, 1982).

Porém, efeitos de maturação são frequentemente cruciais à praticabilidade de propagação massal vegetativamente, conforme BURDON (1982) e a multiplicação de material inteiramente juvenil serā necessārio.

2.1.3. Desenvolvimento de plantas propagadas vegetativamente em comparação com plantas propagadas por sementes

RAUTER (1982) recomenda que antes de envolver-se em um pro grama de propagação vegetativa em larga escala, deve haver garantia que 0 material manterā a sua superioridade desde o estabelecimento até a exploração. Testes comparativos entre clones e plantas propagadas por sementes são geralmente inadequados, embora alguns apresentem diferenças e 
similaridades na taxa de crescimento e forma (ZOBEL e TALBERT, 1982).

Shelbourne e Thul in (1974) citados por RAUTER (1982), encontraram taxas de crescimento inicial de estacas de Pinus radiata menor que em mudas por sementes.

Em testes de campo, FRAMPTON JR. (1986) verificou diferenças em crescimento, resistência a doença e morfologia entre plāntulas de Pinus taeda micropropagadas vegetativamente e mudas de sementes. 0 crescimento atē os 4 anos em altura foi inferior em plântulas micropropagadas e segundo este mesmo autor, este resultado estā grandemente relacionado com a diferença no tamanho inicial das mudas e no crescimento mais lento no primeiro ano.

BERTOLOTI (1986) comparando o comportamento silvicultural de ārvores propagadas vegetativamente e material propagado por sementes com diferentes graus de melhoramento em Eucalyptus grandis, verificou que a estaquia não correspondeu a espectativa teórica. As estimativas de ganhos obtidos em volume de madeira aos 2 anos foram, respectivamente para monoclones e multiclones, $21,3 \%$ e $12,1 \%$ inferior em relação às sementes comerciais, em solo podzōlico vermelho escuro.

Estudando as diferenças entre a parte aérea e o sistema ra dicular em Pinus taeda de 2 anos de idade, FRAMPTON JR. e MACKEAND (1987) verificaram que plāntulas micropropagadas apresentaram tamanho inferior e sistema radicular menos desenvolvido que plantas propagadas por sementes. Em estudos semelhantes, en condições de casa de vegetação, Mackeand e Wisniewski (1982) citados por FRAMPTON JR. e MACKEAND (1987), verificaram que após 6 meses as plântulas de Pinus taeda micropropagadas apre- 
sentavam quase 10 vezes menos rajzes laterais que mudas por sementes. Em outro estudo MORA (1986) observou a associação entre o clone de Eucalyptus spp que apresentou maior crescimento e a presença de raizes terciārias e quaternärias que, provavelmente foram as responsāveis pela maior absorção de āgua e nutrientes. Verificou-se tambēm a ausência de rẩz pivotan te em mudas por estacas.

Por outro lado Rouland (1978) citado por RAUTER (1982), verificou que as estacas de Sitka spmuce cresceram mais em altura e mostraram menor variação em forma. Segundo o mesmo autor, a forma inicial das estacas era ruîm no inīcio mas aos 4 anos era comparāvel à de plantas obtidas por sementes.

Segundo RAUTER (1982), o crescimento mais lento na propagação vegetativa poderia ser atribuĩdo à planta mãe ser fisiologicamente adulta e afirma que se as estacas forem obtidas de material jovem ou rejuvenescido, o resultado também poderia ser diferente.

Hood e Libby (1978), citado por RAUTER (1982), verificaram que as estacas ma is jovens de Pinus radiata apresentaram taxa de crescimento em altura maior no início, porēm mais tarde a taxa de crescimento das estacas mais adultas foi maior.

Hā indicações de que ārvores propagadas vegetativamente de individuos mais velhos crescem mais lentamente do que aquelas tomadas ao acaso de individuos ma is jovens (Talbert et alii 1982, citado por ZOBEL e TALBERT 1984), além de apresentar, segundo ZOBEL e TALBERT (1984), forma anormal dependendo do local em que o propágulo foi retirado da planta mãe. Estes autores citam ainda que o material adulto frequentemente 
apresenta menor taxa de enraizamento e desenvolve menos raizes do que o material fisiologicamente juvenil.

MORA (1986) detectou algumas anormalidades de crescimento em altura e diāmetro dentro de clones de Eucalyptus spp, porém com baixíssima incidēncia, semelhante aos detectados por CHAPERON e QUILLET (1977), que detectaram 0,2 a 1,0\% de estacas de Eucalyptus com desenvolvimento ruim, resultado do crescimento anormal das raízes.

\subsection{Estimativas de Parâmetros Genéticos}

Muitas caracteristicas de interesse no melhoramento florestal são quantitativas, herdadas pela ação de muitos genes de efeito aditivo, cada um contribuindo para herança dos caracteres (DITLEVISEN, 1980), de uma forma bastante complexa (FLANKLIN, 1977). Deve-se lembrar tambēm da importāncia dos genes não aditivos no melhoramento florestal.

A estimativa de parāmetros genéticos possibilita a obtenção de informações sobre a natureza de ação gênica envolvida na herança dos caracteres e fornece base para avaliação dos planos de melhoramento da população, alēm dos conhecimentos que permitem o desenvolvimento de novos enfoques no melhoramento de plantas (ROBINSON e COCKERHAM, 1965). Ainda, as estimativas dos parāmetros genēticos se prestam para orientação do esquema mais adequado de seleção e para avaliação do progresso esperado na seleção (VENCOVSKY, 1969, FONSECA, 1979).

Estimativas de parāmetros genéticos são necessārias para uma suficiente seleção de ārvores, particularmente em gerações avançadas 
(Dean et alii, 1983, citado por MORAES, 1986) e possibilita conhecer a estrutura genética da população (KAGEYAMA et alii, 1977). Entretanto, os parāmetros genéticos sō se aplicam a uma população, na idade observada e nas condições ambientais reinantes para as mesmas (PIRES, 1984), uma vez que em espécies florestais, diversos genes agem diferentemente nos vārios estágios de desenvolvimento da planta.

Os parâmetros genéticos de maior importância para o melhoramento florestal são os componentes de variação genētica, coeficiente de herdabilidade para estimar os ganhos genéticos e as correlações genotīpicas e fenotipicas entre as caracteristicas.

Existem muitos processos para estimar os componentes de variação, mas a base é o experimento em blocos ao acaso ou os látices que, após o ajuste do quadrado médio de tratamentos, se assemelham aos blocos no que concerne à avaliação dos componentes (VENCOVSKY, 1978).

A técnica empregada para decompor a variação total e estimar a magnitude da variāncia de cada componente è a anālise de variāncia. Segundo FONSECA (1979), esta técnica tem, nos ensaios de melhoramento flo restal, dupla finalidade: a) testar diferenças entre tratamentos e b) estimar os componentes da variāncia. Este mesmo autor cita que para 0 geneticista florestal, a segunda finalidade da anālise de variāncia è a ma is importante.

A variāncia genētica pode ser decomposta em variāncia genētica aditiva e não aditiva (dominante e epistācia). Em se tratando de propagação de plantas alógamas por via sexuada, o componente de variân cia ma is importante para o melhoramento é a contribuição devido aos 
efeitos aditivos dos genes (PATERNIANI (1966); FONSECA (1979); FALCONER (1981); VENCOVSKY (1978);. ELDRIDGE (1977) afirma que o melhoramento efetivo pela seleção de uma população depende da presença suficiente de variāncia genētica aditiva.

Portanto ē na existência de variação que reside o sucesso de um trabalho de seleção. Entretanto, dos componentes de variação total, somente aqueles de natureza genética são aproveitāveis na seleção. Consequentemente, todo sucesso do esquema seletivo vai depender da quanti dade da variāncia genética disponīvel em relação à variāncia não genética (VENCOVSKY, 1978).

Porēm, quanto maior o efeito genético não aditivo para uma certa característica, maior serā o potencial para o ganho genético através de propagação vegetativa. Segundo MACKEAND \& WEIR (1984), o efeito genético não aditivo em Pinus taeda é frequentemente igual ou maior do que o efeito aditivo para a característica de produção de madeira e resistência à Cronartium quercuum. Isto significa que o potencial de ganho em melhoramento para produção de madeira pode ser duplicado com a pro pagação vegetativa. Para algumas características como a produção de celulose, o efeito genético não aditivo pode predominar (Jett et alii, 1977, citado por MACKEAND \& WEIR, 1984).

Para algumas características, os ganhos atravēs de regeneração por sementes poderão ser grandes, mas para outras que contém quanti dades significativas de variāncia não aditiva, tais como certas características de crescimento, os ganhos serão pequenos em relação a possibilidade de ganhos na propagação vegetativa (Fielding, 1970, citado por ZOBEL 
e TALBERT, 1984).

SAKAI e MUKAIDE (1966), acrescentam a variāncia competicional na fórmula da variāncia fenotîpica. Segundo estes autores, os efeitos da competição ambiental podem aumentar substancialmente a variāncia total em povoamentos de mistura de genótipos em relação aos povoamentos puros, exercendo influencia nas estimativas de herdabilidade. A competição ocorre entre ārvores de genótipos diferentes, mas não dentro de um mesmo genōtipo.

Segundo ROBINSON e COCKERHAM (1965), os parāmetros genēticos estimados devem ser independentes dos efeitos ambientais, mas esta condição se satisfaz se não houver interação com o ambiente. Para eliminar esta dificuldade, devem-se testar os genōtipos em uma sērie de ambientes, de maneira que se possa separar a variāncia devida à interação do genōtipo e ambiente das variāncias genēticas.

A interação é composta de duas partes conforme VENCOVSKY (1978), sendo uma devida a diferença na variabilidade genética do material dentro do ambiente e a outra devida a falha de correlação entre o material de um ambiente para outro, ou seja, o material superior em um am biente pode não o ser no outro. Deve-se agrupar os ambientes em zonas de plantio de tal forma que haja uma mīnima interação.

Se o ensaio for instalado em um só local, a variāncia genética estimada é na realidade inflacionada, pois além de conter o valor da variāncia genética propriamente dita, contēm os valores devido a interações com locais e anos. No caso de plantas florestais que são perenes, segundo FONSECA (1979), o efeito devido aos anos de plantio parece 
não ser tão importante. Porēm, maiores cuidados devem ser dispensados aos efeitos dos locais, desde que os plantios florestais, de um modo gerai, abranjam grandes āreas.

Segundo ZOBEL e TALBERT (1984), quando os testes são estabelecidos num só local pode conduzir a uma superestimação dos ganhos na seleção, sobretudo quando o material vai ser implantado num local não testado.

Deve-se agrupar os ambientes em zonas de plantio de tal forma que haja uma minima interação entre os sîtios e que os genótipos bem adaptados sejam selecionados visando a estabilidade fenotipica e 0 crescimento vegetativo (BERTOLOTI, 1986).

0 coeficiente de herdabilidade expressa a quantidade de variação genética em relação à variação fenotípica total. Assim, quando o material é propagado pelos meios sexuais, a herdabilidade deve ser calculada com base na variāncia genética aditiva (TODA, 1963), que se refere a genes efetivamente transmitidas aos descendentes por seleção e cruzamento (FONSECA, 1979). Por outro lado, quando o material $\overline{\mathrm{e}}$ propagado vegetativamente, a herdabilidade deve ser baseada na variāncia genética total (TODA, 1963).

Portanto, o coeficiente de herdabilidade pode ser no sentido restrito, quando considera somente a variāncia aditiva em plantas de cruzamento e, no sentido amplo, quando expressa a proporção de variāncia genētica total em relação à variāncia fenotîpica total.

Quanto à estimativa de herdabilidade TODA (1972) afirma 
que não se deve dar muita importāncia na precisão numérica mas distinguir as caracteristicas de alta herdabilidade e aquelas de baixa herdabilidade, po is seguno DITLEVISEN (1980), a herdabilidade não é uma magnitude fixa e depende tanto da população como do meio ambiente.

o coeficiente de herdabilidade é um dos parâmetros mais importantes dentro do programa de melhoramento genētico. A herdabilidade por sī não é um parâmetro instrutivo mas em conexão com o diferencial de seleção, permite estimar o ganho genético a alcançar em uma geração (HATTEMER, 1963). Segundo SQUILLACE et alii (1967) o conhecimento da herdabilidade permite a predição dos ganhos genēticos e auxilia na escoTha de métodos apropriados de melhoramento.

Segundo FALCONER (1981), uma característica com alta herdabilidade pode ser melhorada atravēs de seleção massal, enquanto que para caracterīstica de baixa herdabilidade a seleção por famîlias seria muito mais eficiente.

Caracteristicas de alta herdabilidade sofrem menos a influência da interação genōtipo $x$ ambiente, quando comparadas às caracterîsticas de baixa herdabilidade dentro de uma mesma população (MORAES, 1987). Por outro lado, MORI (1987) comenta que características com diferentes herdabilidades possuem comportamento diferenciado em relação à competição e cita que os valores de herdabilidade encontrados por PATINOVALERA (1986) foram decrescentes para altura, DAP e volume cilindrico, inversamente proporcional aos efeitos competicionais. 0 mesmo autor comenta que quanto maior a herdabilidade da caracteristicas, menor foi 0 efeito competicional no referido es tudo. 
0 ganho genëtico ou o progresso na seleção para determinada característica è o parāmetro que exprime o avanço da geração seguinte em relação à população original, decorrente da seleção ef etuada. Conforme ELDRIDGE (1977) a boa estimativa da quantidade de variação genética e outros parāmetros genéticos são necessārios para predizer o ganho de estratégias alternativas para melhoramento genētico e para escolha da melhor estratégia.

Por outro lado, o estudo de correlação entre caracteres é evidentemente importante nomelhoramento onde a preocupação è em aprimorar o material não para características isoladas, mas para um conjunto de caracteres simultaneamente (VENCOVSKY, 1978). 0 grau de correlação, tanto genotīpica como fenotipica, è de grande importância quando se pratica a seleção num dado carāter pois pode causar mudanças simultāneas em outro carāter.

Quando se atribui maior peso na seleção às características correlacionadas, a seleção de uma resultarā em avanços significativos, tambēm, na outra característica (KAGEYAMA, 1980).

Segundo FALCONER (1981) as caracterīsticas correlacionadas são de interesse por trēs razões: primeiro, o melhoramento de uma caracterîstica pode causar mudanças simultāneas em outra; segundo, o conhecimento de ação pleiotrōpica dos genes e terceiro, conhecer a relação entre uma caracterīstica métrica e o poder adaptativo.

Segundo BURDON (1977) existem dois tipos de correlações ge néticas: a do tipo A, quando ambas as características são avaliadas sobre a mesma planta e a do tipo B, quando duas características são avaliadas sobre indivĩduos diferentes dentro de grupos genéticos. 
0 conhecimento do grau de associação entre características, do ponto de vista genético, constitui-se numa excelente ferramenta para o planejamento das estratégias a serem utilizadas num programa de mel horamento.

MORAES (1987) encontrou correlação genética positiva e a1ta entre as caracterîsticas de crescimento sendo que a correlação altura $x$ volume cilindrico apresentou maior valor para Eucalyptus grandis. Altas correlações genēticas entre caracterīsticas foram encontradas também por KAGEYAMA (1980) em Eucalyptus grandis e PATINO-VALERA (1986) em Eucalyptus saligna.

Conforme cita MUNISWANI (1977), os testes de progēnies clona is possibilitam a avaliação da constituição genētica de ārvores selecionadas. Os problemas encontrados na instalação do teste de progēnies, conforme PATINO-VALERA (1986) são as definições do nümero de famîlias a serem testadas, do nümero de indivíduos à considerar dentro de cada parcela, do número de repetições e ainda da forma da parcela que permita ava liação adequada de cada uma das famīlias.

Com relação à amostragem de populações, 0 ideal $\bar{e}$ assegurar igual representatividade de todas as classes de ārvores e conforme Kemp (1976), citado por FONSECA (1982) a seleção deliberada de ārvores com caracteristicas fenotîpicas desejāveis não é recomendāvel pela aparente redução na variabilidade da população. VENCOVSKY (1978) enfatiza que 0 uso de população de pequeno tamanho pode conduzir a seleção na direção oposta àquela pretendida pelo melhorista, devido ao fenōmeno de oscilação genētica, com riscosmaiores ainda se o alelo desejado ocorre com baixa 
frequēncia.

Ensaios especificos para determinação de parâmetros genéti cos em espécies floresta is são pouco comuns. 0 que se verifica é um apro veitamento dos ensaios de progēnies, que prioritariamente têm objetivos de testar ārvores mães selecionadas na população. Segundo BURLEY et alii (1964) os parāmetros estimados atravēs de testes de progēnies de ārvores selecionadas não se referem diretamente à população e a variāncia genētica entre progénies fica subestimada. Segundo TODA (1972), para que as estimativas dos parāmetros genēticos possam ser generalizadas à população é essencial que os indivíduos sejam tomados ao acaso e afirma que a seleção de indivíduos na população reduzirá os valores de variância total e de variāncia entre famîlias na mesma taxa, mantendo mais ou menos constan te a estimativa de herdabilidade.

Alguns estudos nesse sentido vêm sendo feitos, tal como 0 trabalho de SHELBOURNE e STONECYPHER (1971) que tomaram 280 ārvores ao acaso de uma população, especificamente para determinação de parāmetros genéticos. PINTO JR. (1984) cita que os estudos de variação genética utilizando progênies de polinização livre, obtidas de ārvores selecionadas em populações naturais (não domesticadas) são raros, enquanto que de ārvores selecionadas fenotipicamente em populações melhoradas (em fase de domesticação) são mais frequentes.

2.2.1. Teste de progēnies de polinização aberta

Os testes de progênies instalados tanto a partir de sementes de pol inização livre como de cruzamentos controlados, segundo KAGEYAMA 
(1980a) tem sido importantes na determinação do valor reprodutivo dos individuos selecionados, na estimativa de parâmetros genéticos, para seleção de novos indivĩduos superiores e como fonte de produção de sementes atravēs de sua transformação em pomar de sementes por mudas. São ainda, utilizados para determinar a variāncia genética aditiva e segundo ELDRIDGE (1977) são os únicos meios disponíveis de avaliar a capacidade geral de combinação de ārvores superiores.

Conforme QUIJADA (1980c), a finalidade dos ensaios de progènies é o de estimar o valor genético de um indivíduo com base no comportamento da sua descendéncia ou o valor genético de indivíduos meios irmãos ou irmãos germanos. Este mesmo autor afirma que nos programas baseados na seleção fenotīpica, onde a influência do ambiente é desconhecida e consequentemente a seleção não é muito confiāvel, os ensaios de progēnies são indispensāveis.

Portanto, os testes de progēnies utilizados em programa de melhoramento permitem, segundo QUIJADA (1980c): a) a avaliação do valor de cruzamento (capacidade de combinação das ārvores), b) aval iação dos parāmetros genético-estatîsticos como variância, correlação, herdabilidade, etc., c) avaliação de sub populações para usos especificos e d) ava1 iação de ārvores individuais com fins de seleção continua. Ainda, os testes implantados em uma série de ambientes permitem avaliar a interação genōtipo $x$ ambiente.

Os principais componentes da variação fenotipica de carā ter quantitativo num ensaio, segundo VENCOVSKY (1978) são devido a: diferenças ambientais entre e dentro das parcelas e diferenças genéticas en tre os tratamentos e entre plantas dentro de parcelas. 
Os testes de progēnies de polinização aberta fornecem informações genéticas importantes para definição da estratēgia de melhoramento atravēs da seleção recorrente (KAGEYAMA, 1980b) e constitui-se num método ma is utilizado en espécies florestais.

A determinação da variāncia genética total entre e dentro de progēnies possibilita também conhecer o sistema reprodutivo de uma população. Segundo FONSECA (1982) a relação entre as variāncias genéticas dentro e entre progénies pode ser indicativa do sistema de cruzamento das espécies citando um decréscimo na variāncia genética dentro e um acréscimo na variāncia genética entre, em plantas de autofecundação em relação às espécies que apresentam fecundação cruzada.

Segundo ZOBEL e TALBERT (1984), os testes de progênies per mitem separar as ārvores cujas superioridades fenotīpicas foram produzidas pelas boas condições do ambiente daquelas que apresentam uma superioridade genotipica.

Para espécies florestais, o ensaio de progénies mais utilizado é o de polinização aberta, visando a determinação do valor reprodutivo das ārvores selecionadas e estimativas dos parāmetros genéticos (KAGEYAMA, 1980).

\subsubsection{Teste de progénie clonal}

Hā dois tipos de informações genéticas que podem ser obtidas de estudos de clones, segundo BURDON e SHELBOURNE (1973).

a) estimativa de parâmetros genéticos. Neste caso, a variância genotipica total (que contēm componentes aditivo 
e não aditivo), variāncia ambiental e variância de interação genótipo $x$ ambiente podem ser estimadas de experimentos clonais. Destas variāncias a herdabilidade no sentido amplo pode ser estimada. A covariāncia entre diferentes caracteres pode fornecer estimativas de correlações genotipicas e fenotipicas.

b) Estimativa do valor genotipico dos indivíduos. 0 valor genotîpico total de um indivĩduo sō tem importāncia quan do a propagação comercial for por via vegetativa, mas pode ou não estar estreitamente relacionado ao valor de reprodução, que tem grande importāncia na propagação por semente.

Esses autores citam que os clones podem prover estimativas de variāncia e covariāncia genotípica e fenotīpica em populações e do valor genētico das ārvores matrizes. Quando plantados em diversos locais, eles podem fornecer informações sobre a interação genōtipo-ambiente. Mas estas informações, a não ser que sejam aplicadas a situações onde a propagação vegetativa é utilizada em larga escala, pode ser tendenciosa por fatores como topōfise e efeitos de genes não aditivos.

A estaquia e muito mais adequada que a enxertia para obter informações genēticas, pois neste ūltimo existe o efeito do porta-enxerto e da interação enxerto $x$ porta-enxerto, o que demandaria modelos mais elaborados para anālise. Em teoria, a ausēncia de variação genética entre ortet (ārvore original) e ramets (propágulos vegetativos) de um clone, 
em contraste a considerävel variação genética entre seedlings de uma progēnie (famîia), aumenta a precisão e eficiēncia na obtenção de informação genética, (BURDON e SHELBOURNE, 1973).

0 clone, que naturalmente não apresenta variāncia genētica, è essencialmente ūtil porque mostra a variāncia ambiental como sua variāncia fenotīpica dentro de clones (TODA, 1963). Com a obtenção da estimativa da variāncia ambiental torna-se mais fäcil estimar a variāncia genética subtraindo-se a variāncia fenotīpica da população.

Entretanto a variação dentro do clone pode ter três componentes conforme ROULAND (1973):

a. variação devida ao ambiente;

b. variação não genētica, devida a diferença anatōmica e fisiológica, is to é, tamanho da estaca, posição da esta ca no ramo, desenvolvimento da raíz, conteúdo nutricional, idade fisiolōgica, etc.;

c. variação devida a diferenças genēticas atuais por causa das diferentes funções no "ortet", chamado de efeito topöfise.

BURDON (1982) cita que a topōfise e a maturação podem criar sērias variações interclonais. Segundo o mesmo autor, o efeito da maturação progressiva em particular, poderia afetar a performance do clone de forma que seja diferente entre a fase juvenil e a fase adulta.

A propagação vegetativa permite distinguir ārvores boas ou ruins, principalmente devido ao efeito ambiental daquelas que são 
inerentemente retas ou tortuosas. Segundo LONGMAN (1976), è possivel ter ma is certeza da seleção, quando esta for baseada em linhas ou parcelas de àrvores, todas do mesmo genótipo.

Os testes clonais, conforme HOWLAND et alii (1978) deverão tornar possivel estudar uma gama de variação dentro da espēcie, identificar caracterîsticas desejāveis e padrões de crescimento, predizer forma e produtividade na fase adulta, alēm de permitir a seleção de clones para uso em plantações comerciais. Ainda, os experimentos clonais podem ter maior vantagem quando a competição entre ārvores influencia o carāter em questão (BURDON e SHELBOURNE, 1973).

Em Norway spruce (Picea abies), ROULAND (1973) verificou que a variação entre clones, em altura, diâmetro e hābito de ramificação é devida a influência do ambiente, especialmente a competição entre ārvores e a idade.

A avaliação dos clones parece ser pouco utilizada como fer ramenta de medida dos valores reprodutivos das ārvores matrizes, embora pareça ser vantajosa para características de alta herdabilidade como densidade bāsica em Pinus taeda (Anon, 1980, citado por BURDoN, 1982). Em Pinus radiata, Carlson, citado por BURDON (1982), observou baixa correlação entre clones e progēnies propagadas por sementes.

2.3. Estimativas de Herdabilidade no Sentido Restrito e no Sentido Amplo

A estimativa de herdabilidade no sentido amplo tem sido es tudada para vārias caracterīsticas e espécies. HARAHAP e SOERIANEGARA 
(1977) utilizaram o método de NOH (1972) em pomar clonal de Tectona grandis, de 23 anos de idade, e encontraram os valores de estimativas de herdabilidade no sentido amplo para as seguintes caracteristicas: altura total $\left(h^{2}=0,92\right)$, comprimento do fuste $\left(h^{2}=0,74\right)$, DAP $\left(h^{2}=0,71\right)$, diāmetro à altura do enxerto $\left(h^{2}=0,69\right)$ e diāmetro a $10 \mathrm{~cm}$ acima do enxerto $\left(h^{2}=0,69\right)$.

Os valores da herdabilidade para altura total e comprimento do fuste foram maiores que para diāmetros. Os resultados são contrārios aos obtidos por Dijamhuri (1975), citado por HARAHAP e SOERIANEGARA (1977) para teca, utilizando o método proposto por SAKAI e HATAKAYAMA (1963) onde a herdabilidade no sentido amplo para altura total, comprimento do fuste, diāmetro e forma do tronco foram $0,67,0,69,0,87$ e 0,94 respectivamente.

Para Pinus merkusii, SUHAENDI et alii (1976) citado por estes mesmos autores, encontraram a herdabilidade no sentido amplo para al tura total, diāmetro e retidão do tronco de $0,40,0,80$ e 0,86 , respecti vamente.

A herdabilidade no sentido amplo das caracterīsticas āngulos dos ramos, número de ramos por verticilo e comprimento do internōdio foi estudado por NOH (1972) em enxertos de Pinus densiflora, plantados no espaçamento de $4 \times 4 \mathrm{~m}$, em banco clonal em 1961. As herdabilidades para àngulos dos ramos e comprimento do internōdio foram 0,753 e $\quad 0,774$, respectivamente, mas para o número de ramos por verticilo foi relativamente baixa $(0,465)$ comparada com outras duas características. Por essa razão, o autor espera maior ganho genético na seleção para āngulo dos 
ramos e comprimento do internōdio. Poucos autores estudaram a herdabilidade no sentido amplo e no sentido restrito ao mesmo tempo. Entre eles, TODA (1972) estimou as herdabilidades en plantios de Cryptomeria japonica originados de sementes e de clones propagados por estaquia. Os valores obtidos foram, respectivamente para sementes e clones, 0,89 e 0,77 para a característica altura da planta, 0,84 e 0,74 para circunferéncia do tronco, 0,74 e 0,44 para comprimento do fuste, 0,82 e 0,57 para diāmetro da copa e 0,86 e 0,57 para espessura da casca.

Para as caracteristicas de florescimento, CHAVES et azii (1983) observaram forte controle genētico, como demonstram os dados iniciais de coeficientes de herdabilidade no sentido amplo: 0,63 e 0,53 para florescimento feminino, 0,52 e 0,46 para florescimento masculino e 0,28 e 0,43 para número de estrōbilos masculinos por inflorescência, em Pinus caribaea e Pinus oocarpa, respectivamente. Estes mesmos autores citam que VARNELL et alii (1967), estudando Pinus elliottii var. elliottii com a idade variando de 14 e 17 anos, provenientes de estacas enraizadas, verificaram que as herdabilidades no sentido amplo para florescimento fariam de 0,49 a 0,50

Fielding e Brown (1960) citados por TODA (1963), estudaram a densidade especiffica da madeira em plantações de Pinus radiata de 13, 19 e 20 anos de idade, provenientes de estacas e encontraram herdabilidades estimadas de $0,7,0,7$ e 0,5 , respectivamente.

A estimativa de herdabilidade no sentido restrito tem sido estudada por muitos autores. KEDHARNATH e VAKASHASYA (1977), em teste de progènies de Eucalyptus tereticornis, mostraram que as estimativas de 
herdabilidade no sentido restrito foram 0,25 para altura e 0,17 para diāmetro, aos 4 anos de idade.

0s principa is resultados de coeficientes de herdabilidades no sentido restrito, obtidos no Brasil a partir de ensaios de progênies de polinização aberta para diversas caracteristicas e espēcies são (Tabela 1):

Os valores de herdabilidade individual no sentido restrito obtidos em Eucalyptus saligna por PATINO-VALERA (1986), aos 32 meses de idade foram maiores para forma do tronco $(0,45)$, vindo a seguir al tura $(0,28)$, diāmetro $(0,18)$, ārea basal $(0,13)$ e volume cilîndrico $(0,13)$. Es te mesmo autor encontrou uma tendéncia de diminuição dos valores de herdabilidade entre 15 e 24 meses e permanecendo estāvel atē 32 meses de idade.

Para a característica densidade da madeira, os resultados mostram, no geral, uma al ta herdabilidade.

Em Eucalyptus grandis, KAGEYAMA et alii (1982) encontraram coeficientes de herdabilidade no sentido restrito para densidade da madeira, ao nivel de plantas individuais, valores bastante altos nos très locais de ensaio, variando de 0,70 a 1,00 o que indica a existência de forte controle genético para esta caracteristica. As herdabilidades ao nivel de mëdias de famīlias foram bastante altas, com valores variando de 0,67 a 0,79 .

Vārios autores apresentaram resultados referentes a herdabilidades para densidade da madeira, segundo BRITO e BARRICHELO e FERREIRA (1978), (Tabela 2): 


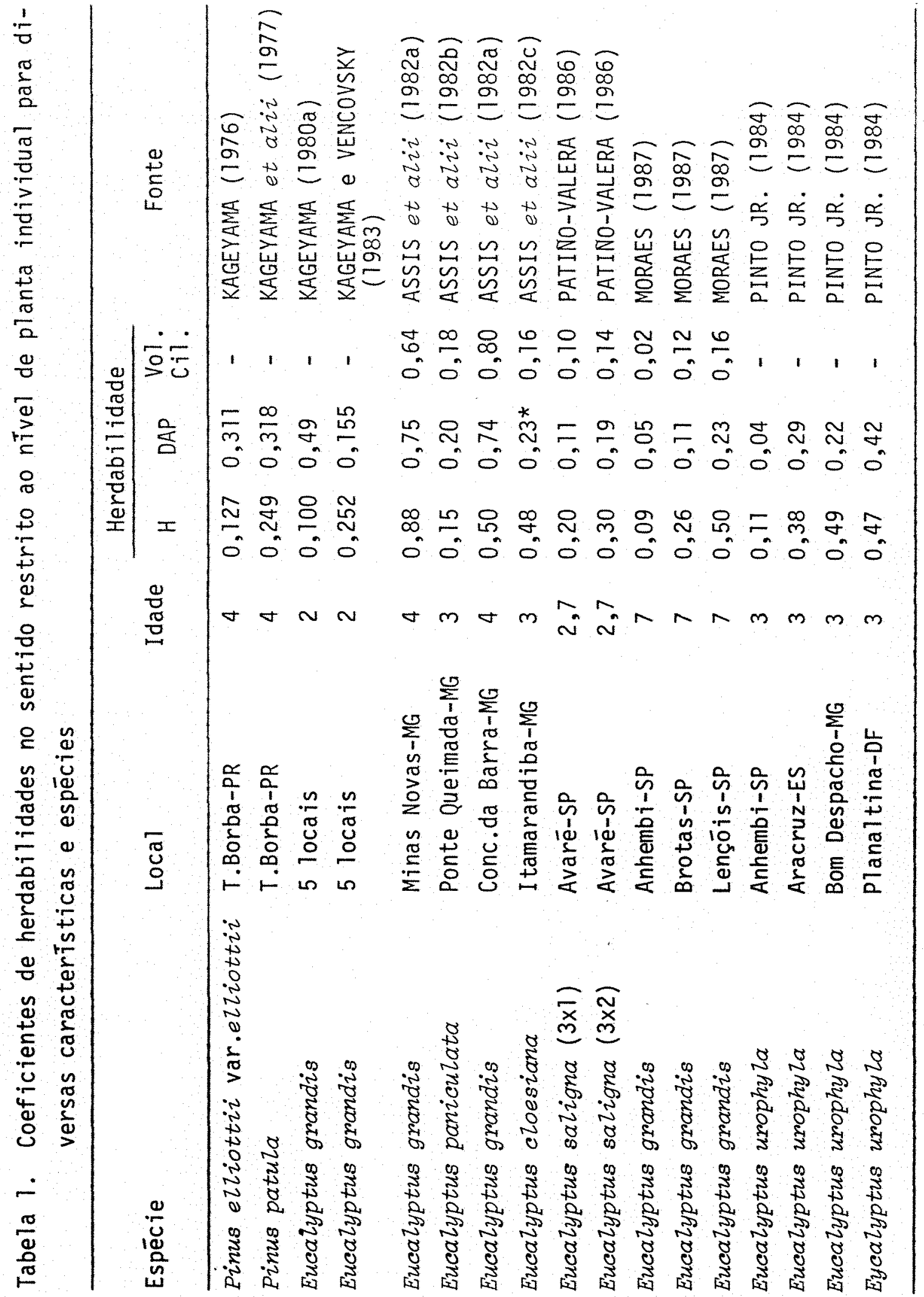


Tabela 2. Coeficiente de herdabilidade para densidade da madeira, segundo BRITO \& BARRICHELO e FERREIRA (1978)

\begin{tabular}{|c|c|c|c|c|}
\hline Espēcie & Idade & Método & $\begin{array}{c}h^{2} \\
s . a^{*}\end{array}$ & $\begin{array}{l}h^{2} \\
s \cdot r^{\star \star}\end{array}$ \\
\hline \multirow[t]{7}{*}{ Pinus radiata } & 6 meses & Pol.livre & - & 0,20 \\
\hline & 8 meses & Clonal & $0,45-0,75$ & - \\
\hline & 8 meses & Clonal & $0,54-0,75$ & - \\
\hline & 10 meses & Clonal & $0,50-0,75$ & - \\
\hline & 13 meses & Clonal & 0,70 & - \\
\hline & 19 meses & Clonal & 0,70 & - \\
\hline & 20 meses & Clonal & 0,50 & - \\
\hline \multirow[t]{7}{*}{ Pinus taeda } & 1 mès & Clonal & 0,17 & - \\
\hline & 5 meses & Clonal & 0,64 & - \\
\hline & 2 meses & Pol. contr. & - & 0,20 \\
\hline & 2 meses & Pol. contr. & - & $0,37-0,49$ \\
\hline & 2 meses & Pol.livre & - & 0,55 \\
\hline & 5 meses & Pol. Tivre & - & $0,76-0,87$ \\
\hline & 6 meses & Pol.tivre & - & $0,64-1,00$ \\
\hline \multirow[t]{4}{*}{ Pinus elziottii } & 5 meses & Clonal & $0,46-0,73$ & - \\
\hline & 14 meses & Clonal & 0,73 & - \\
\hline & 14 meses & Pol.contr. & - & 0,56 \\
\hline & 14 meses & Pol. livre & - & 0,21 \\
\hline Picea abies & 18 meses & Clonal & 0,86 & - \\
\hline
\end{tabular}

* Herdabilidade no sentido amplo

** Herdabilidade no sentido restrito. 
HATTEMER (1963) apresenta uma lista de estimativas de herdabilidades estudadas por vārios autores, em diversas espēcies florestais. Em resumo, as herdabilidades citadas para algumas caracteristicas foram (Tabela 3):

Os valores de herdabil idade permitem estimar o ganho genético com a seleção e avaliar a estratégia de melhoramento mais adequado. SHELBOURNE (1969) fez uma comparação de ganho genético para forma do tronco e diāmetro, para diferentes métodos de melhoramento baseado nos da dos de variāncia de ensaios de progēnies de pinus radiata de 14 anos de idade, de polinização aberta. Foram estimados maiores ganhos em retidão do tronco em pomar clonal da 2 a geração (herdabilidade $=0,87$ para forma e 0,27 para diāmetro), mas a propagação massal por estaquia dos melhores clones mostrou maiores ganhos em diāmetro $\left(h^{2}=0,45\right)$ e quase tão altos em forma $\left(h^{2}=0,76\right)$ em quase um terço do tempo.

0 método de pomar de sementes de $2^{\mathrm{a}}$ geração (seleção de novas ārvores superiores em testes de progēnies de irmãos germanos, de ca pacidade de combinações mais altas) pôde ser instalada 28 anos após seleção fenotĩpica, enquanto que a propagação vegetativa de melhores clones pōde ser instalada após 11 anos.

Os diferentes valores de herdabilidade encontrados para a mesma espēcie por diversos autores são em função, principalmente, dos diferentes mētodos utilizados na sua determinação, dos diferentes materia is genēticos, dos locais, da idade de avaliação, entre outros fatores. 


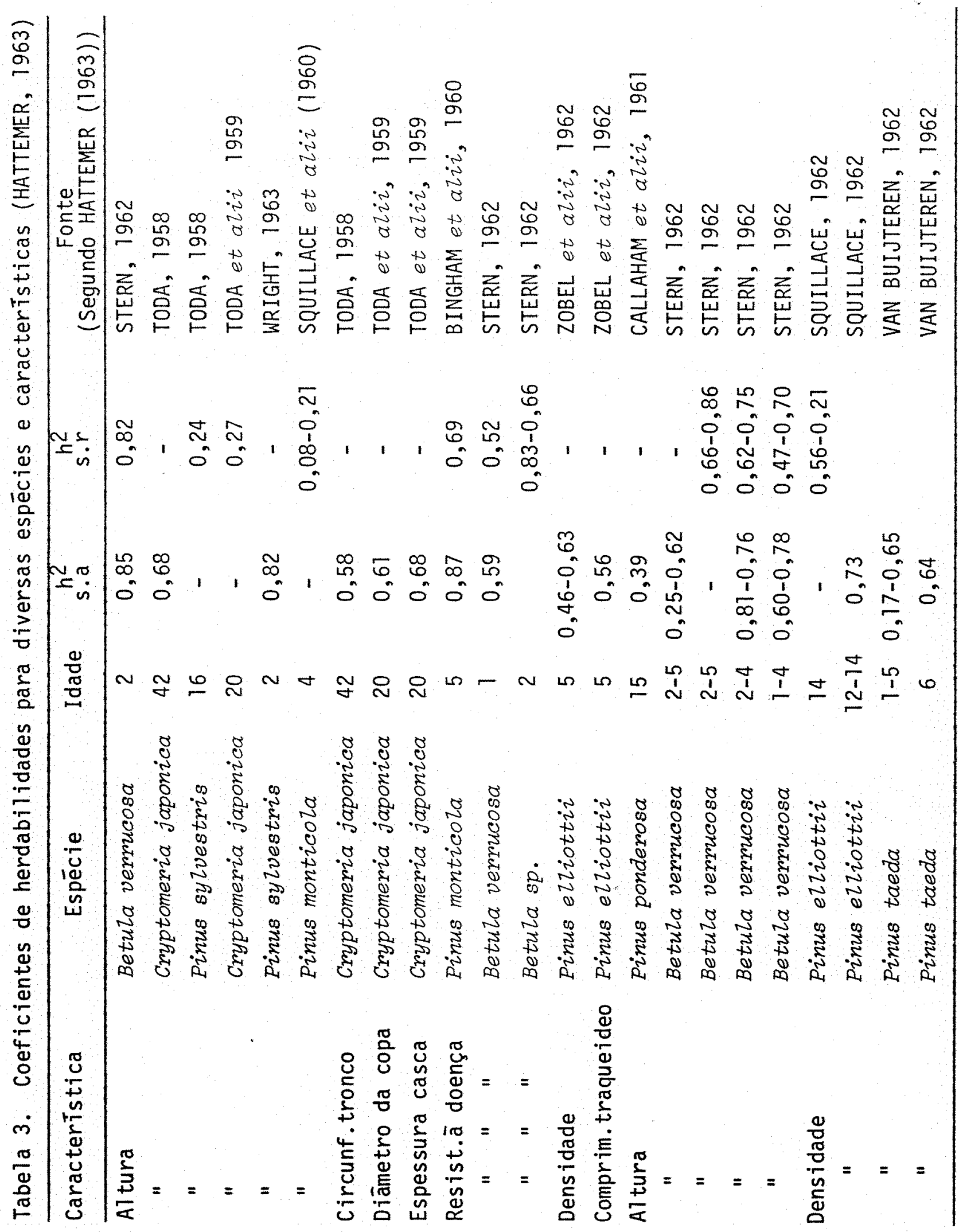


3. MATERIAL E METODOS

\subsection{Material}

\subsubsection{Material genético}

As ārvores matrizes para instalação dos testes de progēnies foram obtidas a partir de população de Eucalyptus grandis implantada em 1976 na região de Telémaco Borba, Estado do Paranā. A procedēncia das sementes desta população ē de Mogi-Guaçū, SP, onde foi introduzido inicialmente da Austrālia:

Origem: Coffs Harbour, NSW, Austrālia - latitude $30^{\circ} 00^{\prime} \mathrm{S}$ longitude $125^{\circ} 55^{\prime} \mathrm{E}$, altitude $90 \mathrm{~m}$

Procedēncia: Mogi-Guaçū, SP = latitude $22^{\circ} 11$ 'S, longitude de $47^{\circ} 7$ 'W e $600 \mathrm{~m}$ de altitude.

As 45 ärvores matrizes superiores foram selecionadas fenotipicamente aos 7 anos de idade, levando em consideração principalmente as caracteristicas de crescimento em altura e diāmetro, forma de tronco, forma da copa e resistēncia à geadas. A intensidade de seleção foi aproxi madamente de $1: 2000$. 
Estas ārvores foram cortadas para rejuvenescimento e, a partir da brotação de touça, efetuar a propagação vegetativa por estaquia, a fim de instalar os testes de progénies clonais. Ao mesmo tempo, as somentes destas matrizes foram coletadas para instalação do teste de polinização livre e considerou-se como verdadeira a relação de meios irmãos. Para comparação foram utilizadas 36 ārvores tomadas ao acaso da mesma população base, denominadas de testemunhas, para instalação do teste, sendo que 20 árvores são comuns tanto nas progēnies clonais, como nas de sementes.

3:1.2. Descrição do local de instalação do experimento

a) Localização

0 ensaio foi instalado em maio de 1985, na Fazenda Monte Alegre, municĩpio de Telémaco Borba, estado do Paranā, com as seguintes características geogrāficas: latitude $24^{\circ} 14^{\prime} \mathrm{S}$, longitude $50^{\circ} 35^{\prime} \mathrm{W}$ e alti tude $850 \mathrm{~m}$.

\section{b) Cl ima}

A Fazenda Monte Alegre è caracterizada por um clima subtropical úmido, com a temperatura média anual de $18,8^{\circ} \mathrm{C}$, com geadas pouco frequentes e precipitação média de $1.460 \mathrm{~mm}$, uniformemente distribuĩda ao longo do ano e sem deficiēncia hídrica.

Segundo o sistema internacional de Koeppen, o clima $\bar{e}$ do tipo $\mathrm{Cfb}$, ou seja, do tipo mesotērmico e úmido, sem estiagem, em que a temperatura mēdia do mès mais quente não atinge $22^{\circ} \mathrm{C}$. 
c) Perfil geológico

A Fazenda Monte Alegre estā dentro do Segundo Planalto Paranaense e é praticamente toda ocupada pela série Tubarão.

\subsection{Mētodos}

\subsubsection{Insta lação dos ensaios}

Devido a natureza do ensaio foram instalados, nas mesmas condições, os seguintes testes de progēnies:

a. teste de progēnies de meios irmãos, de ārvores selecionadas e de ärvores tomadas ao acaso (testemunhas);

b. teste de progênies clonais, das mesmas ärvores selecio nadas e de testemunhas.

Estes testes foram instalados um ao lado do outro, casualizados en cada bloco, de modo a permitir a anālise e comparação dos dados entre os diferentes métodos de propagação (progênies de meios irmãos e progēnies clonais) e os diferentes materiais genéticos (ärvores selecionadas e a acaso). Cada um destes testes foi instalado em esquema de 1ātice. 0 preparo do solo consistiu em um combate às formigas em toda área do ensaio e posteriormente de 2 gradagens. 0 ensaio foi instalado em solo anteriormente ocupado com Pinus sp., com adubação.

A produção de mudas para o ensaio seguiu a sistemātica nor mal de trabalho de viveiro, tendo-se o cuidado de manter todos os tratamentos perfeitamente identificados. 0 sistema de produção de mudas 
foi uniformizado tanto para progénies por estaquia como por sementes.

A estaquia foi realizada em casa de vegetação conforme CAMPINHOS JR. (1982), utilizando-se do ācido indolyl-butīrico, 6.000ppm di luîdo em talco neutro, $25 \mathrm{mg} / \mathrm{estaca}$, para estimular o enraizamento. As mudas enraizadas sofreram um processo de aclimatação e rustificação. No caso de sementes, foi feita uma semeadura direta em tubetes de modo a evitar repicagens de mudas.

\subsubsection{Del ineamento experimental}

0 ensaio foi instalado obedecendo ao delineamento em látice triplo 9x9, segundo COCHRAN e COX (1983), com as seguintes características: 3 repetições, 81 tratamentos (45 matrizes selecionadas e 36 ārvores ao acaso), o espaçamento de $3,0 \times 3,0 \mathrm{~m}$ e parcelas lineares de 10 plantas. A área total do experimento foi de $56.61 \mathrm{~m}^{2}$, com bordadura externa dupla.

3.2.3. Condução do experimento

Foi mantida uma vigilāncia sistemātica para evitar o ataque de pragas, principalmente de formigas cortadeiras. Sempre que necessário, foram efetuados tratos cultura is para controle das ervas daninhas, na fase inicial de crescimento das mudas. Em função das falhas, foi efetuado um replantio, 20 dias apōs o plantio, visando homogenejzar o número de plantas, jā que o crescimento em diāmetro está correlacionado com o espaçamento. 


\subsubsection{Coleta de dados}

Aos 6 e 9 meses apōs a instalação do ensaio foram avaliados altura total individual das ārvores em metros e porcentagem de sobrevivēncia. Um ano apōs a instalação do ensaio, e a cada 6 meses seguintes, foram medidos por parcela: altura total em metros, DAP (diāmetro à altura do peito) em $\mathrm{cm}$ e a percentagem de sobrevivēncia.

A coleta de dados para as características altura total e diāmetro do tronco foi ao nivel de plantas individuais, enquanto que para sobrevivéncia foi ao nivel de totais de parcelas. 0 volume cilindrico foi obtido para cada uma das ārvores individuais, atravēs da utilização dos respectivos dados de altura e diāmetro. Para a anālise estatĩstica da porcentagem de sobrevivēncia foi utilizada a transformação dos dados em $\operatorname{arc} \cdot \operatorname{sen} \sqrt{x}$.

\subsubsection{Anālise estatistica e estimação de variâncias genēticas e fenotipicas}

A anālise de variāncia individual foi feita em Tátice, para cada caracterīstica, conforme COCHRAN e COX (1983). O modelo matemātico utilizado foi:

$$
y_{i j k m}=u+t_{i}+b_{j k}+r_{k}+e_{i j k}+d_{i j k m}
$$

onde:

$$
\begin{aligned}
Y_{i j k m}= & \text { observação feita no indivĩduo } m \text {, do tratamento } i \text {, no bloco } j \\
& \text { e da repetição } k \\
u \quad= & \text { média geral }
\end{aligned}
$$




$$
\begin{aligned}
& t_{i}=\text { efeito do tratamento } \\
& b_{j k}=\text { efeitos de bloco dentro de repetições } \\
& e_{i j k}=\text { efeito do erro intrabloco } \\
& d_{i j k m}=\text { efeito dentro de parcelas }
\end{aligned}
$$

As estimativas de variāncias genēticas e ambientais e de parāmetros afins para as diferentes caracteristicas foram obtidas através dos esquemas de anālises de variāncia individual em lātice, pela decomposição do quadrado médio dos tratamentos ajustados em sua esperança matemātica. A variāncia do erro foi obtida a partir do quadrado médio do erro, que corresponde ao erro efetivo.

3.2.5.1. Progēnies de meios irmãos

A estrutura simplificada de anālise de variância em lātice utilizada em progênies de meios irmãos, ao nível de médias de parcelas, foi: 
F.V.

Tratamentos ajustados

- Matrizes selecionadas
G.L.

$\left(k^{2}-1\right)$

$(m-1)$

$Q_{6}$

Q.M.

$E(Q M)$

$Q_{7} \quad \frac{\sigma^{2} d}{\bar{n}}+\sigma^{2} e+r \sigma^{2} p$
- Tes temunhas
$(t-1)$

Erro efetivo

$$
(k-1)(r k-k-1)
$$

$Q_{4} \quad \frac{\sigma^{2} d}{\bar{n}}+\sigma^{2} e$

Dentro de parcelas

$$
r k^{2}(n-1)
$$

$\mathrm{Q}_{3}$

$\sigma^{2} d$

- Matrizes selecionadas

$r m(n-1)$

$\mathrm{Q}_{2}$

$\sigma^{2} d_{1}$

- Testemunhas

$$
r t(n-1)
$$

$Q_{7}$

$\sigma^{2} d_{2}$

onde:

$k=n$ o de tratamentos por bloco

$r=n$ ọ de repetições

$m=n$ o de matrizes selecionadas

$t=n \varphi$ de testemunhas

$n, n_{1}$ e $n_{2}=$ no médio de plantas/parcela respectivamente para total de tratamentos, matrizes selecionadas e testemunhas.

$\sigma^{2} \mathrm{~d}, \sigma^{2} \mathrm{~d}_{1}$ e $\sigma^{2} \mathrm{~d}_{2}=$ variāncia dentro da parcela, respectivamente para total de tratamentos, matrizes selecionadas e tes temunhas

$\sigma^{2} e=$ variāncia devida ao erro entre parcelas 
$\sigma^{2} p=$ variância devida a progēnies

$\sigma^{2} p_{1}=$ vartāncia devida a progénies das matrizes selecionadas

$\sigma^{2} p_{2}=$ variāncia devida a progēnies das testemunhas

$\sigma^{2} d=(3 / 4) \sigma^{2} A+\sigma^{2} D+\sigma^{2} d a$, sendo, $\sigma^{2} A=$ variāncia aditiva;

$\sigma^{2} D=$ variāncia dominante;

$\sigma^{2} d a=$ variāncia dentro ambiental.

A variāncia dentro de parcelas foi obtida independentemente da anālise de variāncia, através da média ponderada dos quadrados médios dentro das parcelas, levando-se em conta as variações do número de plantas em cada parcela, conforme KAGEYAMA (1980a).

Desta forma, as estimativas de variāncia foram:

Estimativa de variância

Dentro de parcelas

Erro

Progēnies

Aditiva

Fenotipica

Tratamentos

Matrizes selecionadas
Testemunhas

\section{e}


Os coeficientes de variação genëtica $\left(C V_{g}\right)$, coeficiente de
$\left(C V_{d}\right)$ variação ambiental $\left(\mathrm{CV}_{e}\right)$ e coeficiente de variação dentro de parcelas foram estimados pela expressão abaixo, em porcentagem em relação à média $(\bar{X})$ :

$$
\begin{aligned}
& C V_{g} \%=\frac{\sigma p}{\bar{x}} 100 \\
& C V_{e^{\%}}=\frac{\sigma e}{\bar{x}} 100 \\
& C V_{d} \%=\frac{\sigma d}{\bar{x}} 100
\end{aligned}
$$

\subsubsection{Progènies clonais}

\begin{tabular}{|c|c|c|c|}
\hline F.V. & G.L. & $Q M$ & E. (QM) \\
\hline Tratamentos a justados & $k^{2}-1$ & $Q_{7}$ & $\frac{\sigma^{2} \mathrm{da}}{\bar{n}}+\sigma^{2} e+r \sigma^{2} c l$ \\
\hline - Matrizes & $m-1$ & $Q_{6}$ & $\left.\frac{\sigma^{2} \mathrm{da}}{\bar{n}_{1}}+\sigma^{2} \mathrm{e}_{1}+r \sigma^{2} \mathrm{cl}\right]_{1}$ \\
\hline - Testemunhas & $t-1$ & $Q_{5}$ & $\frac{\sigma^{2} \mathrm{da}}{\bar{n}_{2}}+\sigma^{2} \mathrm{e}_{2}+r \sigma^{2} \mathrm{cl}$ \\
\hline Erro efetivo & $(k-1)(r k-k-1)$ & $Q_{4}$ & $\frac{\sigma^{2} \mathrm{da}}{\bar{n}}+\sigma^{2} \mathrm{e}$ \\
\hline Dentro de parcelas & $r k^{2}(n-1)$ & $Q_{3}$ & $\sigma^{2} \mathrm{da}$ \\
\hline - Matrizes & $m(n-1)$ & $Q_{2}$ & $\sigma^{2} \mathrm{da}_{1}$ \\
\hline - Testemunhas & $r t(n-1)$ & $Q_{j}$ & $\sigma^{2} \mathrm{da}_{2}$ \\
\hline
\end{tabular}

As esperanças do quadrado médio para o teste de progēnie clonal, tanto para ārvores selecionadas como para sem seleção foram: 
onde:

$$
\begin{aligned}
& \sigma^{2} \mathrm{cl}=\text { variāncia entre clones } \\
& \sigma^{2} \mathrm{cl} 1=\text { variāncia entre clones das matrizes selecionadas } \\
& \sigma^{2} \mathrm{cl}_{2}=\text { variāncia entre clones das testemunhas } \\
& \sigma^{2} \mathrm{da}, \sigma^{2} \mathrm{da}_{1} \text { e } \sigma^{2} \mathrm{da}_{2}=\text { variāncia ambiental dentro da parcela clonal }
\end{aligned}
$$

Da mesma forma que em progēnies de meios irmãos, a variāncia dentro ambiental foi obtida atravēs da mëdia ponderada dos quadrados médios dentro das parcelas, considerando-se o número de plantas por parcela. As estimativas de variāncia para progēnies clonais foram obtidas como a seguir:

Estimativas de variāncia
Tratamentos

Matrizes

Testemunhas
Dentro de
parcelas

Erro

$$
\sigma^{2} e=Q_{4}-\frac{\sigma^{2} \mathrm{da}}{\bar{n}}
$$$$
\sigma^{2} e=Q_{4}-\frac{\sigma^{2} \mathrm{da}_{1}}{\bar{n}_{1}}
$$$$
\sigma^{2} \mathrm{da}_{1}=\mathrm{Q}_{2}
$$$$
\sigma^{2} \mathrm{da}_{2}=\mathrm{Q}_{1}
$$

$$
\sigma^{2} d a=Q_{3}
$$$$
\sigma^{2} c l_{1}=\frac{Q_{6}-Q_{4}}{r}
$$$$
\sigma^{2} c l=\frac{Q_{7}-Q_{4}}{r}
$$

$$
\begin{aligned}
\sigma^{2} F & =\sigma^{2} \mathrm{cl}+\sigma^{2} \mathrm{e}+ \\
& +\sigma^{2} \mathrm{da}
\end{aligned}
$$

$$
\sigma^{2} e=Q_{4}-\frac{\sigma^{2} \mathrm{da}_{2}}{\bar{n}_{2}}
$$$$
\sigma^{2} \mathrm{cl}_{2}=\frac{Q_{5}-Q_{4}}{r}
$$ 
0 coeficiente de variação genētica entre clones $\left(\mathrm{CV}_{\mathrm{Cl}}\right)$ e o coeficiente de variação dentro ambiental $\left(\mathrm{CV}_{\mathrm{da}}\right)$ em porcentagem da média $(\bar{X})$, foram estimados pela expressão:

$$
\begin{aligned}
& \mathrm{CV}_{\mathrm{Cl}} \%=\frac{\sigma \mathrm{Cl}}{\bar{x}} \cdot 100 \\
& \mathrm{CV}_{\mathrm{da}} \%=\frac{\sigma \mathrm{da}}{\bar{x}} \cdot 100
\end{aligned}
$$

Os coeficientes de variação experimental foram calculados a partir do quadrado médio do erro efetivo das anālises em látice.

0 valor de $F$ para progēnies ajustadas, foi obtido atravēs da soma dos quadrados para esta fonte de variação testando-se o mesmo con tra o erro efetjvo.

Para determinação das estimativas de variāncia optou-se pela anālise em lātice, mesmo naqueles casos de baixa eficiēncia, conforme MORAES (1987).

3.2.6. Anālise de variāncia conjunta para métodos de propagação, envoivendo as ārvores selecionadas e testemunhas sem se1eção

A anālise de variāncia conjunta para os métodos de propagação foi efetuada a partir da mēdia de tratamentos ajustados das anālises individuais de látice. O modelo matemātico utilizado, considerandose o efeito do mētodo de propagação como fixo, foi: 


$$
\bar{Y}_{i j m n}=u+t_{i}+b_{j m}+a_{m}+(t a)_{i m}+\bar{e}_{i j m}+\bar{d}_{i j m n}
$$

onde:

$\bar{Y}_{i j m r}=$ observação feita no indivíduo $n$ do tratamento $i$, no bloco $j$, no método de propagação $m$

$$
u=\text { média geral }
$$

$t_{i}=$ efeito do tratamento

$b_{j m}=$ efeito de bloco dentro do mētodo de propagação

$a_{m}=$ efeito do método de propagação

$(\text { ta })_{j m}=$ efeito da interação tratamento por mētodo de propagação

$\bar{d}_{i j m n}=$ efeito dentro de parcelas

$\bar{e}_{i j m}=$ efeito do erro experimental

0 erro utilizado na anālise foi o erro médio entre os erros efetivos das anālises individuais. Foi respeitada a diferença de no mā$x$ imo 4 vezes entre os quadrados mēdios dos erros das anālises individuais para a realização da anālise conjunta, conforme PIMENTEL GOMES (1985).

3.2.7. Estimativa dos coeficientes de herdabilidade $\left(h^{2}\right)$

A partir das estimativas das variāncias genēticas e não genéticas foram estimados os coeficientes de herdabilidade:

a) coeficientes de herdabilidade no sentido restrito (em progēnies de meios irmãos): 
- Ao nivel de plantas individuais:

$$
h^{2}=\frac{4 \bar{\sigma}^{2} p}{\bar{\sigma}^{2} p+\bar{\sigma}^{2} e+\bar{\sigma}^{2} d}=\frac{\bar{\sigma}^{2} A}{\bar{\sigma}^{2} F}
$$

- Entre médias de famîlias de meios irmãos

$$
h^{2} m=\frac{\bar{\sigma}^{2} p}{\bar{\sigma}^{2} p+\frac{\bar{\sigma}^{2} e}{r}+\frac{\bar{\sigma}^{2} d}{\bar{n} r}}=\frac{\frac{1}{4} \bar{\sigma}^{2} A}{\bar{\sigma}^{2} F}
$$

- Dentro de familitias de meios irmãos

$$
h^{2} d=\frac{3 \bar{\sigma}^{2} p}{\bar{\sigma}^{2} d}=\frac{\frac{3}{4} \bar{\sigma}^{2} A}{\bar{\sigma}^{2} d}
$$

Obs.: no caso das variāncias $\sigma^{2} A, \sigma^{2}$ e $\sigma^{2} F$ das förmulas anteriores, leia-se $\sigma^{2} A_{1}, \sigma^{2} e_{1}$ e $\sigma^{2} F_{1}$ para matrizes selecionadas e $\sigma^{2} A_{2}, \sigma^{2} e_{2}$ e $\sigma F_{2}$ para as testemunhas.

b) coeficientes de herdabilidade no sentido amplo (em progènies clonais)

- Ao nivel de plantas individuais:

$$
h^{2}=\frac{\sigma^{2} c l}{\sigma^{2} c l+\sigma^{2} e+\sigma^{2} d a}
$$

- Entre médias de clones:

$$
h_{m}^{2}=\frac{\sigma^{2} c l}{\sigma^{2} c l+\frac{\sigma^{2} e}{r}+\frac{\sigma^{2} d a}{n r}}
$$


Obs.: no caso das variāncias $\sigma^{2} \mathrm{cl}, \sigma^{2}$ e e $\sigma^{2}$ da das förmulas anteriores, leia-se $\sigma^{2} \mathrm{cl}_{1}, \sigma^{2} \mathrm{e}_{1}$ e $\sigma^{2} \mathrm{da}_{1}$ para matrizes selecionadas e $\sigma^{2} \mathrm{cl}_{2}, \sigma \mathrm{e}_{2}$ e $\sigma^{2} \mathrm{da}_{2}$ para testemunhas.

3.2.8. Estimativas de progressos genēticos na seleção

Foram estimados os ganhos genéticos para os diferentes esquemas de seleção, tanto entre progênies clonais como entre e dentro de progēnies de meios irmãos, conforme citados por VENCOVSKY (1978).

\begin{tabular}{lll}
\hline Progresso genético Progénies de meios irmãos & $\begin{array}{c}\text { Progénies } \\
\text { clona is }\end{array}$
\end{tabular}

Seleção massal

(2 sexos)

$$
k_{1} \frac{\sigma^{2} A}{\sqrt{\sigma^{2} p+\sigma^{2} e+\sigma^{2} d}}
$$

$K_{1} \frac{\sigma^{2} c l}{\sqrt{\sigma^{2} c l+\sigma^{2} e+\sigma^{2} d a}}$

Seleção entre e den tro de familias

(2 sexos)

$$
\frac{k_{1} \frac{1}{4} \sigma^{2} A}{\sqrt{\sigma^{2} p+\frac{\sigma^{2} e}{r}+\frac{\sigma^{2} d}{\bar{n} r}}}+\frac{k_{2} \frac{3}{4} \sigma^{2} A}{\sqrt{\sigma^{2} d}}
$$

Seleção entre clones

$$
k_{1} \frac{\sigma^{2} c l}{\sqrt{\sigma^{2} c l+\frac{\sigma^{2} e}{r}+\frac{\sigma^{2} d a}{\bar{n} r}}}
$$

onde:

$$
\begin{aligned}
K_{1} \text { e } K_{2}= & \text { intensidade de seleção entre }(20 \%) \text { e dentro }(10 \%) \text { de pro- } \\
& \text { gênies, respectivamente. } \\
\sigma^{2} A= & \text { variāncia aditiva }
\end{aligned}
$$




$$
\begin{aligned}
\sigma^{2} p & =\text { variāncia entre progēnies de meios imãos } \\
\sigma^{2} c l & =\text { variāncia entre progénies clonais } \\
\sigma^{2} d & =\text { variāncia dentro de progénies de meios irmãos } \\
\sigma^{2} d a & =\text { variāncia dentro de clones (ambiental) } \\
n & =\text { nümero médio de plantas/parcela } \\
r & =\text { nümero de repetições }
\end{aligned}
$$




\section{RESULTADOS E DISCUSSAOO}

4.1. Resultados das Anālises de Variāncia Individua is

A sobrevivēncia média das progēnies de meios irmãos, aos 30 meses de idade, foi maior que nas progénies clonais como mostra a Tabela 4 .

A anālise de variāncia em lātice não mostrou significāncia para a sobrevivência entre as progēnies de meios irmãos, enquanto que - teste $F$ mostrou diferenças altamente significativas entre progénies clo nais. Os coeficientes de variação experimental mostram valores maiores para as progénies cloria is em relação às progēnies de meios irmãos. A eficiēncia do látice foi de $113,02 \%$ no teste de progēnies de meios irmãos e de $111,15 \%$ no teste clonal, o que justificou a utilização desse delineamento experimental. A menor sobrevivēncia das progēnies clonais deveu-se principalmente ao baixo pegamento no plantio, ocasionado provavelmente pela diferença na qualidade fisiológica da muda produzida por estaquia e por semente. De acordo com os estudos feitos por FRAMPTON JR. e MACKEAND 


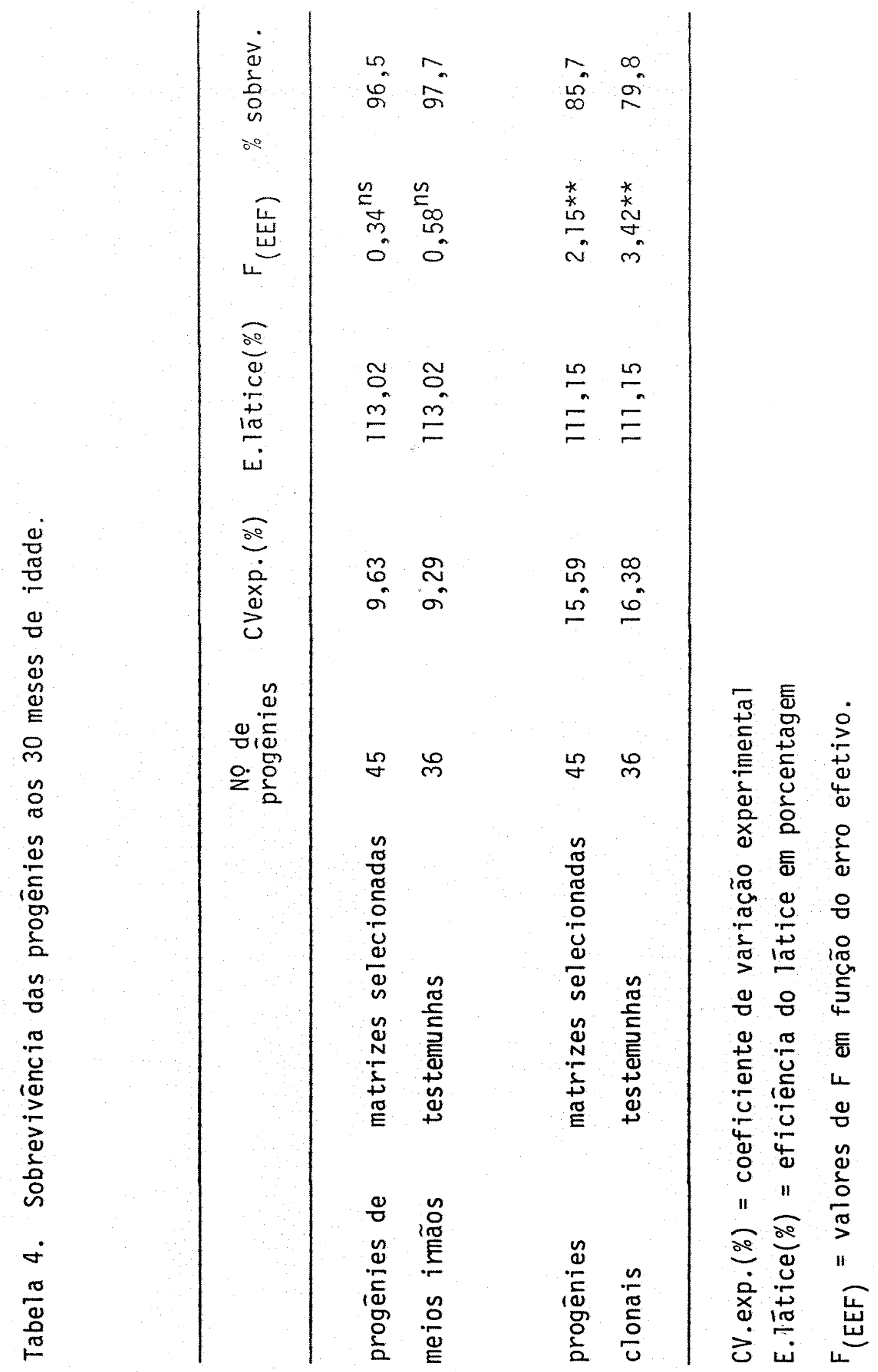


(1988), as pläntulas de Pinus taeda micropropagadas apresentaram o sistema radicular menos desenvolvido do que as mudas produzidas através de sementes.

os resultados das anāilises de variância individuais para as caracteristicas estudadas, envolvendo a altura, o diāmetro e o volume cilindrico são apresentados nas Tabelas 5,8 e 11 respectivamente.

Os valores de $\mathrm{F}$ da anālise de variāncia individual para altu ra (Tabela 5) mostraram variações genéticas significativas, tanto para pro génies de meios irmãos como para progēnies clonais, nos do is mētodos de pro pagação, sendo que os valores de F foram bem maiores nas progénies clonais.

A eficiência do Tătice foi de $132,76 \%$ nos testes de progēnies de meios irmãos e de $109,55 \%$ nos testes de progênies clonais, o que justificou a utilização deste delineamento experimental.

Os resultados de coeficientes de variação experimental encontrados para altura foram baixos, variando de 3,44 a $4,01 \%$, mostrando boa eficiência estatistica para a anālise.

Para a caracteristica altura de plantas, as progēnies de meios irmãos apresentaram um crescimento médio de $16,29 \mathrm{~m}$ aos 30 meses de idade. No teste de progēnies clona is a média geral foi de $15,70 \mathrm{~m}$. No teste de progénies de meios irmãos, as matrizes selecionadas apresentaram um crescimento médio para al tura de plantas de $16,38 \mathrm{~m}$ enquanto que as testemunhas apresentaram $16,16 \mathrm{~m}$, aos 30 meses de idade. 


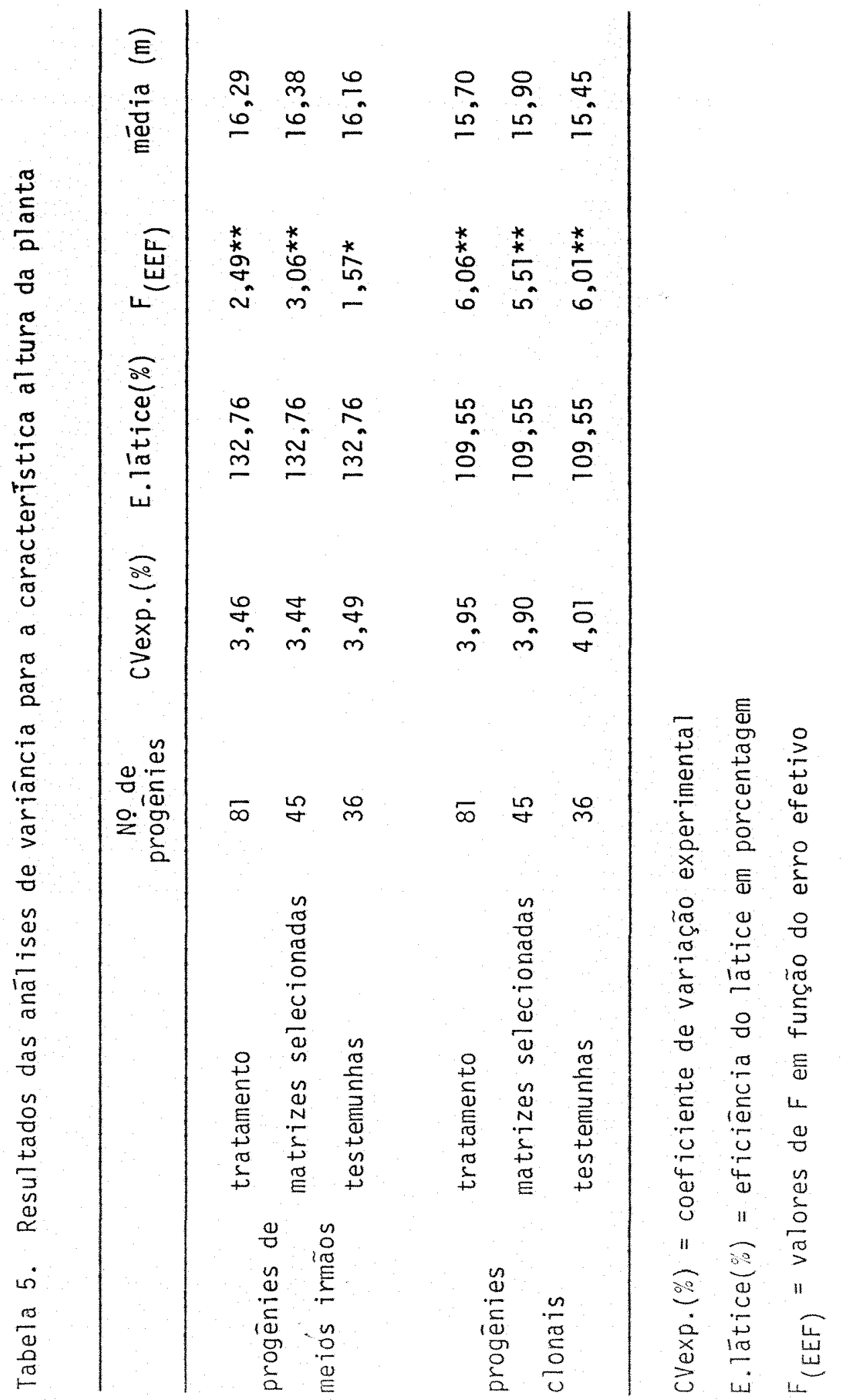


No teste clonal, as mesmas matrizes selecionadas quando propagadas vegetativamente, mostraram-se inferiores no crescimento, com altura média de $15,90 \mathrm{~m}$. Este valor é ainda superior às testemunhas clonais sem seleção que apresentaram $15,45 \mathrm{~m}$, aos 30 meses de idade.

Nas Tabelas 6 e 7 estão apresentados os dados comparativos de altura média, respectivamente entre matrizes selecionadas e testemunhas sem seleção para os dois métodos de propagação, e entre progénies de meios irmãos e progénies clonais para as matrizes e testemunhas.

Na Tabela 6 observa-se que as matrizes selecionadas apresentam pequena superioridade em relação às testemunhas $11,36 \%$ na progēnie de meios irmãos e $2,91 \%$ na progênie clonal), aos 30 meses de idade. Verifica-se também uma ligeira tendência de recuperação no crescimento em al tura nas matrizes selecionadas, indicando o ganho real como reflexo da seleção efetuada. O ganho real aos 30 meses de idade foi maior para as progènies clonais em relação às progēnies de meios irmãos, indicando a melhor efetividade na seleção quando se propaga vegetativamente. Uma possỉvel explicação seria a utilização da variāncia genética total nos clones, conforme cita BURDON e SHELBOURNE (1973), enquanto que nas progēnies de meios irmãos somente a variāncia genética aditiva é utilizada.

Segundo LONGMAN (1976), è possível ter mais certeza da seleção, quando esta for baseada em parcelas de ārvores, todas do mesmo genōtipo, e TODA (1963) afirma que o clone é essencialmente ūtil porque mostra a variância ambiental como sua variāncia fenotípica dentro de clones. 


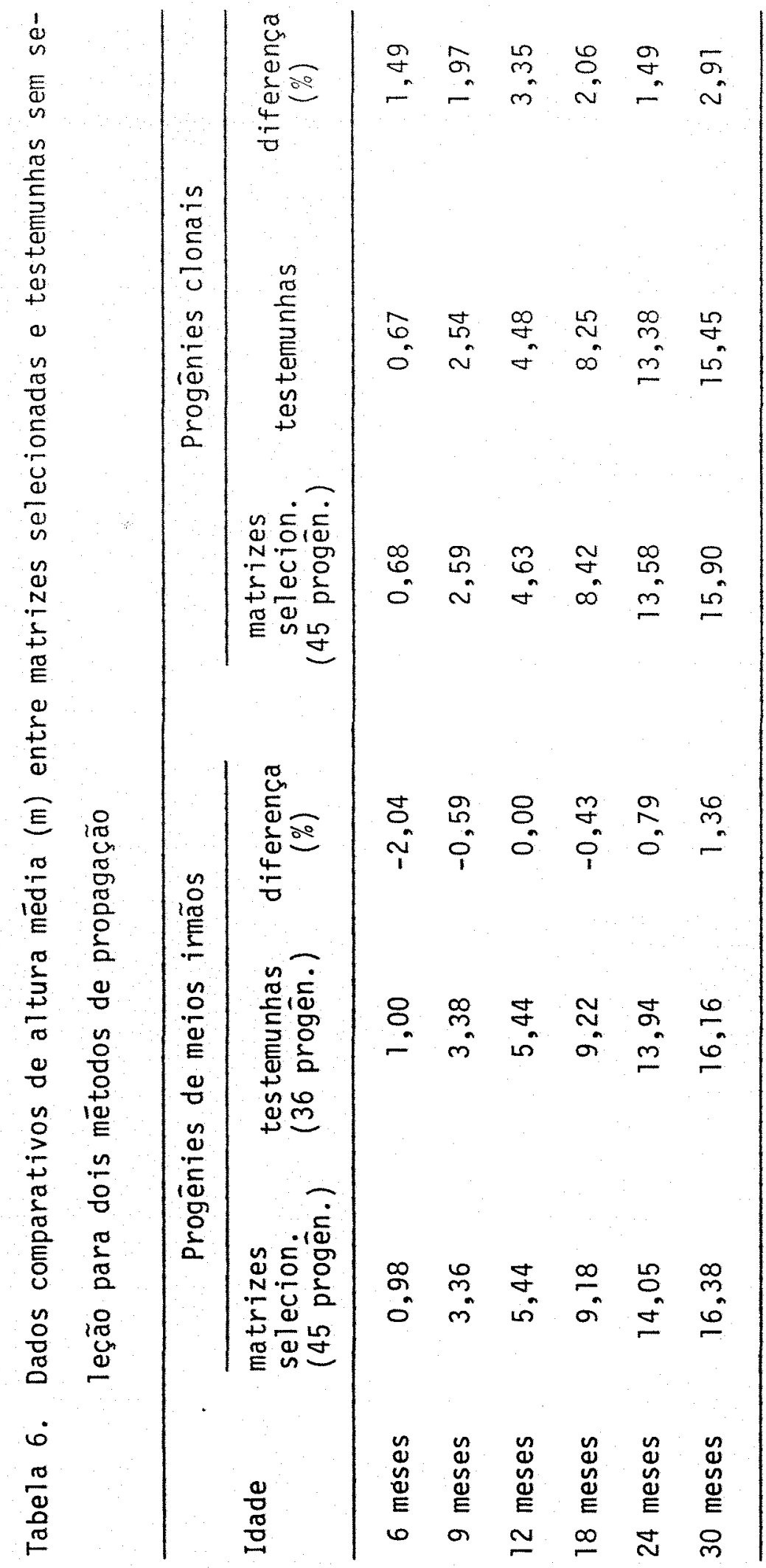




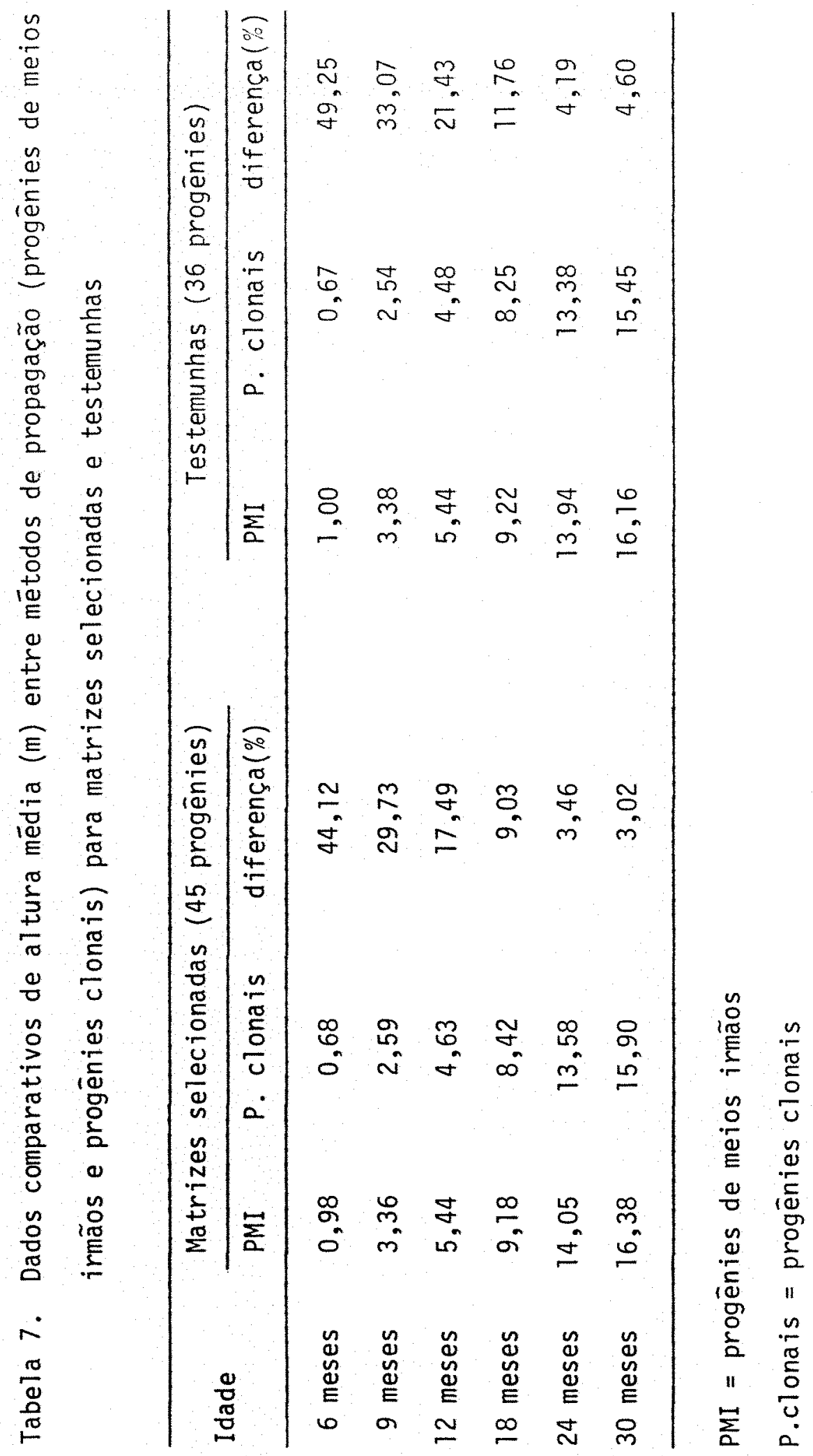


Uma outra possivel explicação seria de que a estaquia influenciaria na idade fisiológica dos clones, permitindo atingir a maturidade mais cedo em relação às plantas propagadas por sementes e, desta forma, possibilitaria a avaliação precoce do comportamento das ārvores na idade mais avançada. Jā na comparação entre métodos de propagação, observase na Tabela 7 que havia uma grande superioridade nas progēnies de meios irmãos em relação às progênies clona is $(44,12 \%$ nas matrizes selecionadas e $49,25 \%$ nas testemunhas) aos 6 meses de idade. Esta superioridade diminuiu para $3,02 \%$ respectivamente nas matrizes selecionadas e nas testemunhas, aos 30 meses de idade.

Atē a idade da avaliação não se verificou nenhuma superioridade da propagação vegetativa em relação à propagação por sementes. Estes resultados concordam com o que foi encontrado por BERTOLOTI (1986) em Eucalyptus grandis, FRAMPTON JR. (1986) em Pinus taeda e Shelbourne e Thul in (1974), citado por RAUTER (1982), em Pinus radiata.

As progénies clonais propagadas por estaquia apresentaram um crescimento inicial lento em altura, ocasionando diferenças relativamente grandes em relação às progēnies propagadas por sementes. Essas diferenças em valores absolutos não foram recuperadas atē os 30 meses de idade, porēm, en valores percentuais houve diminuição considerāve1. 0 cres cimento inicial lento nos clones é tambēm citado por FRAMPTON JR. (1988) e MACKEAND e WISNIEWSKI (1982), em Pinus taeda. Segundo estes mesmos autores, isso se deve à diferença no tamanho inicial das mudas e sistema radicular menos desenvolvido que nas plantas propagadas por sementes. Ainda, o crescimento ma is lento na propagação vegetativa poderia ser atribuīdo $\bar{a}$ 
nlanta mäe, que fornece os propägulos ser fisiologicamente adulta, conforme cita Rauter (1982) e Talbert et alii (1982), citados por ZOEEL e TALBERT (1984). Partindo da suposição de que as testemunhas propagadas por sementes devem ser iguais às testemunhas propagadas por estaquia, a diferença entre os dois métodos de propagação de 4,60\% aos 30 meses de idade comprova a existéncia do efeito da qualidade fisiológica da muda na propagação vegetativa. A diferença entre progēnies de meios irmãos e progênies clonais para as matrizes selecionadas foi de $3,02 \%$ aos 30 meses de idade, menor em relação à diferença verificada anteriormente para as testemunhas. Essa diminuição da diferença nas matrizes selecionadas se deve provavelmente ao efeito da variância genētica não aditiva na propagação vegetativa.

Para a característica diāmetro (DAP), foram verificadas variações significativas entre progēnies aos 30 meses de idade. 0s valores de $F$ obtidos nas anālises de variāncia individual em lätice foram significativos ao nivel de $1 \%$ tanto em progénies de meios irmãos como em progénies clonais, sendo que os valores foram ligeiramente maiores neste ūitimo.

Os coeficientes de variação experimental ( $\left.\mathrm{CV}_{\text {exp }}\right)$ para diāmetro apresentaram valores baixos, sendo $4,18 \%$ para progēnies de meios irmãos e 5,69\% para progēnies clonais, mostrando boa precisão experimental.

As eficiências do látice que é resultado da relação entre o erro do bloco ao acaso pelo erro efetivo do látice, em porcentagem, foram baixos sendo $105,27 \%$ e $109,05 \%$, respectivamente para progēnies de meios irmãos e para progēnies clonais. 


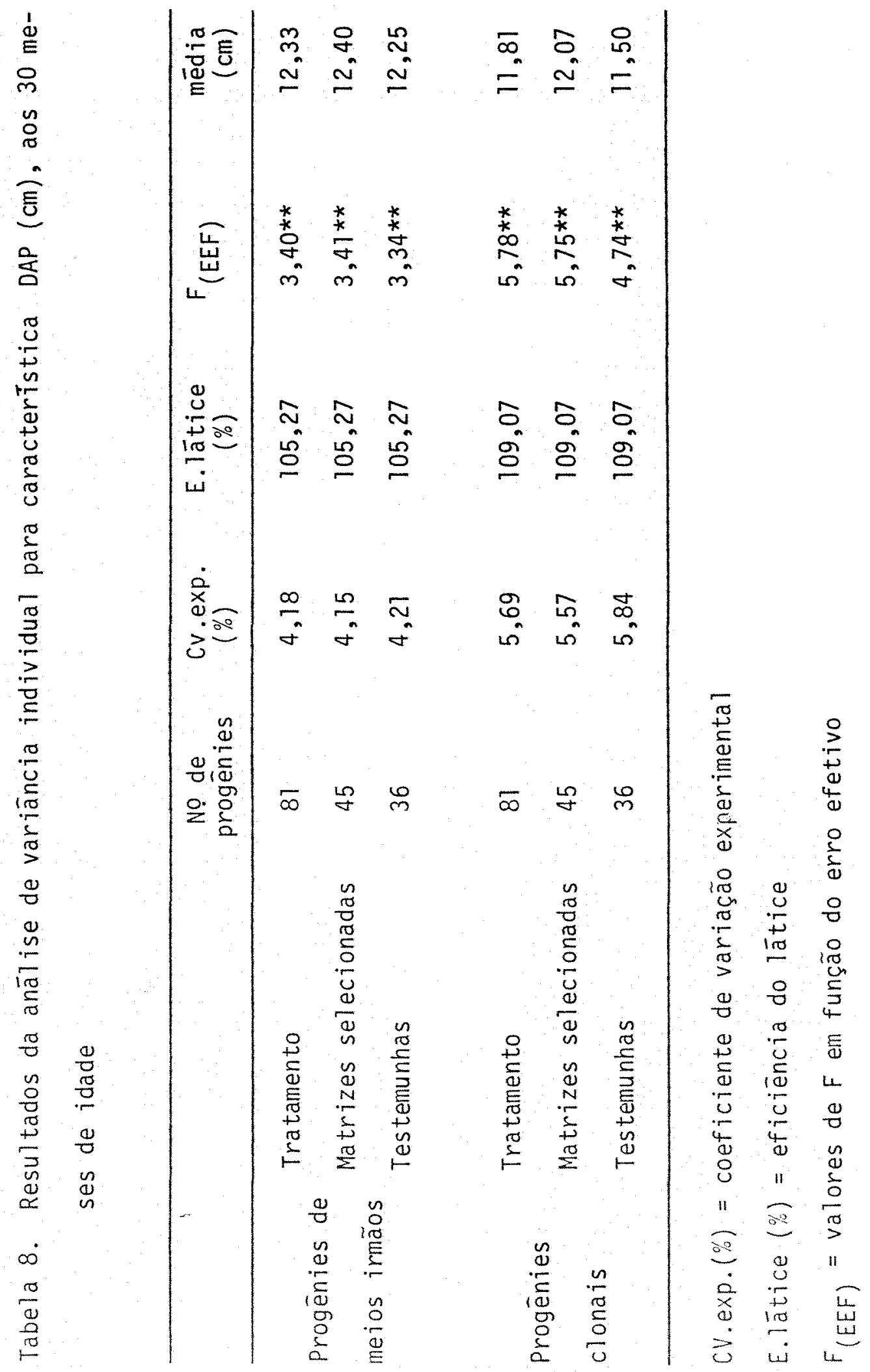


0 crescimento médio em diâmetro nas progénies de meios irmãos foi de $12,33 \mathrm{~cm}$ aos 30 meses de idade, enquanto que nas progénies clona is a média geral foi de $11,81 \mathrm{~cm}$. As matrizes selecionadas apresentaram um diāmetro mëdio de $12,40 \mathrm{~cm}$ enquanto que as testemunhas apresentaram $12,25 \mathrm{~cm}$. Já no teste clonal, as mesmas matrizes selecionadas mostraram um crescimento de $12,07 \mathrm{~cm}$ e as testemunhas $11,50 \mathrm{~cm}$.

Estes valores mostram a mesma tendencia verificada para característica altura. Nas Tabelas 9 e 10 estão apresentados os valores com parativos de diāmetro: entre matrizes selecionadas e testemunhas para os dois métodos de propagação; e entre progénies de meios irmãos e progénies clonais para matrizes e testemunhas.

Pela Tabela 9 verifica-se que hā uma pequena superioridade em diāmetro nas matrizes selecionadas em relação às testemunhas sem seleção, sendo de $0,01 \%$ no caso de propagação por sementes (progēnies de meios irmãos) e de $4,96 \%$ no caso de propagação vegetativa (progēnies clonais). 0 crescimento em diāmetro mostrou, tambēm, tendēncias semelhantes à característica altura, quando se compara matrizes selecionadas e testemunhas. 0 ganho real para DAP foi maior nas progénies clonais indicando maior eficiência na seleção em relação às progēnies de meios irmãos, conforme discutido anteriormente para altura.

Na comparação entre métodos de propagação, observa-se na Tabela 10 que aos 12 meses havia uma superioridade muito grande entre progēnies de meios irmãos e progênies clonais (42,36 para matrizes selecionadas e 39,61 para testemunhas). 


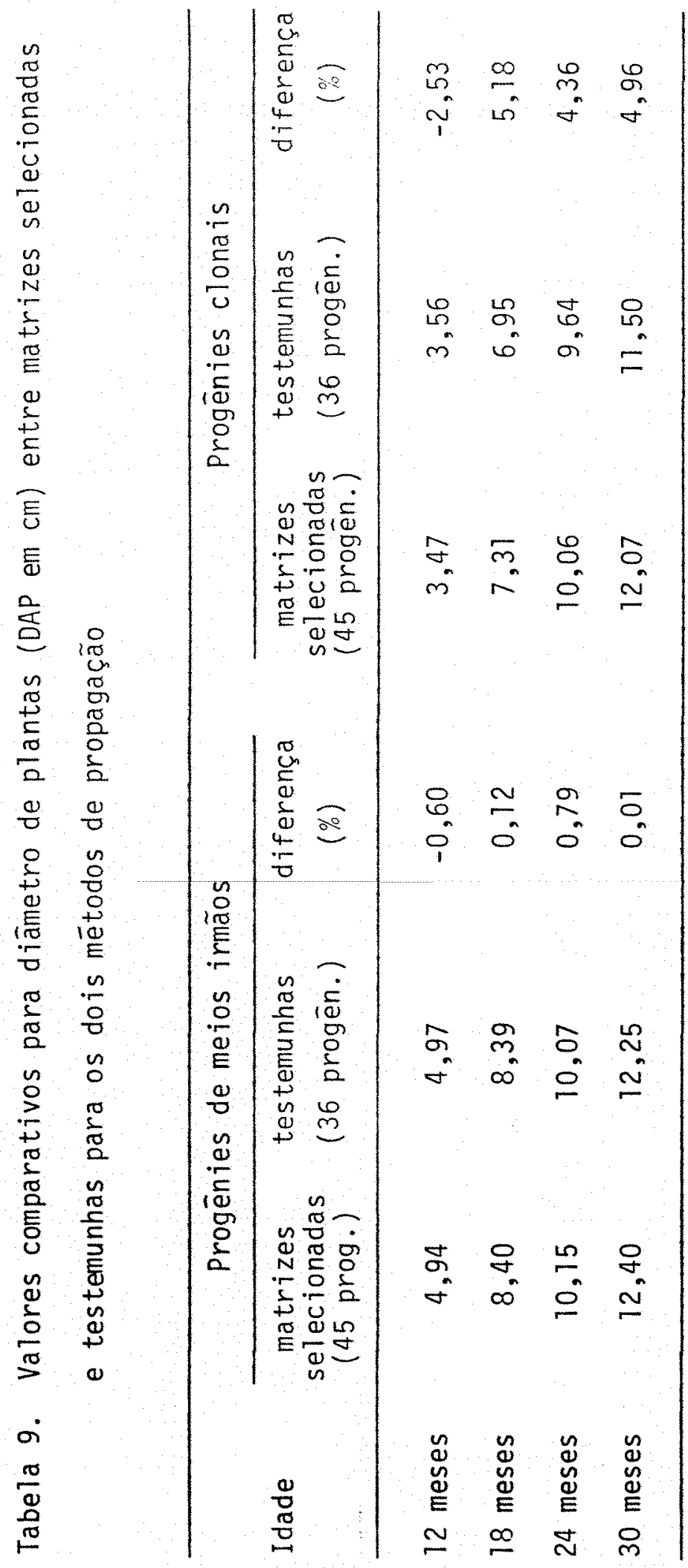




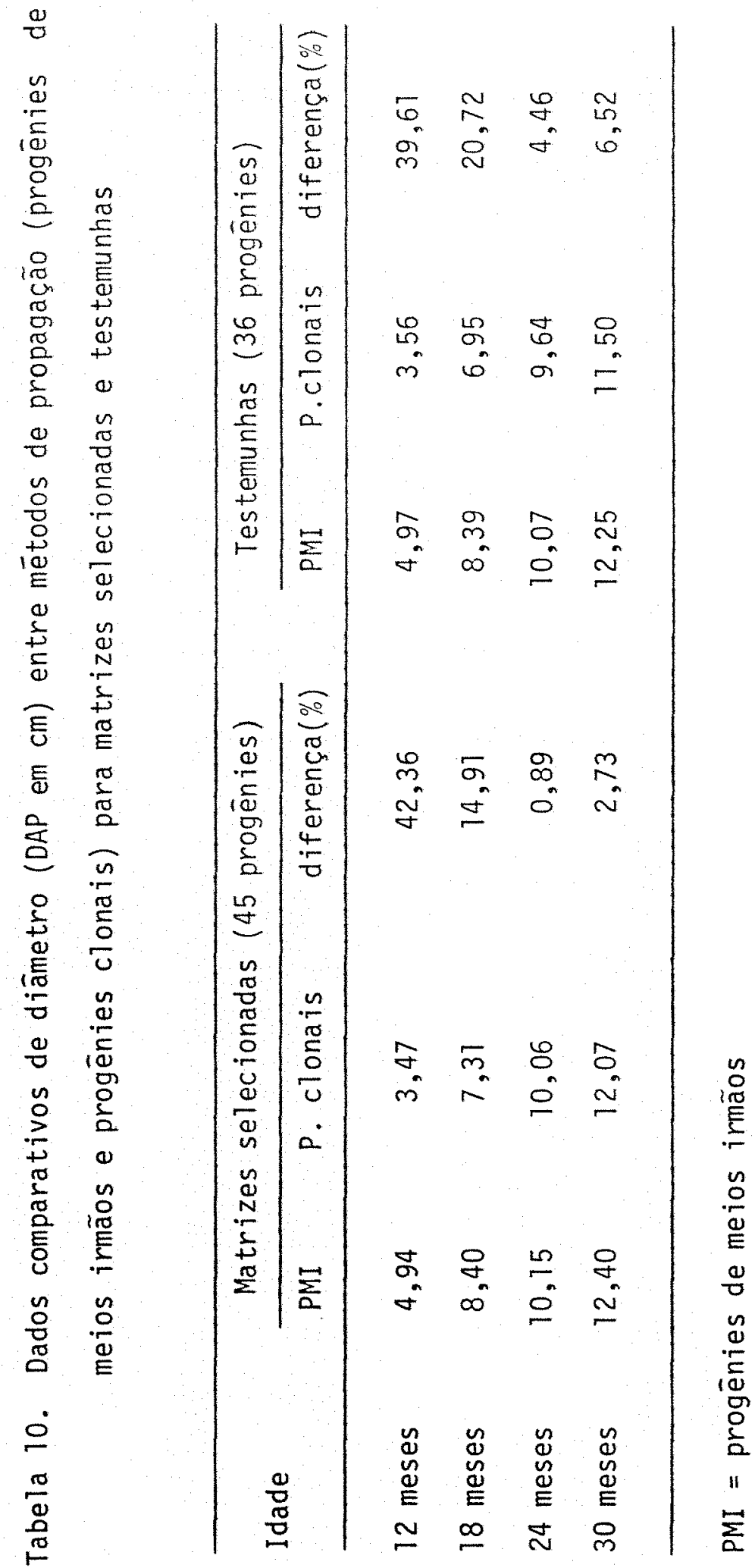


Aos 30 meses de idade, a superioridade diminuiu para $2,73 \%$ e $6,52 \%$, respectivamente para matrizes selecionadas e para testemunhas. 0 lento crescimento inicial en diāmetro, tambëm foi observado nos clones devido provavelmente ao efeito da estaquia na qualidade fisiológica das mudas, conforme discutido anteriormente para altura da planta. o efeito da diferença na fisiologia da muda aos 30 meses de idade na característica diāmetro foi de $6,52 \%$, considerando-se que as testemunhas propagadas por sementes deveriam ser iguais às testemunhas clonais. Para as matrizes selecionadas a diferença no diāmetro entre progēnies de meios irmãos e progênies clonais foi de $2,73 \%$ aos 30 meses de idade, demonstrando que o efei to da fisiologia da muda deve ter sido compensado pelo efeito da variāncia genética não aditiva na propagação vegetativa.

Para a caracteristica volume cilindrico (Tabela 11), os coe ficientes de variação experimental foram mais baixos nas progēnies de meios irmãos mostrando um valor médio de $9,05 \%$ enquanto que em progénies clonais foi de $11,86 \%$, valores que demonstram uma boa eficiēncia estatistica.

Os valores de eficiēncia do lātice encontrados foram de $103,65 \%$ nos testes de progénies de meios irmãos e de $110,05 \%$ nos testes de progēnies clonais, mostrando que o uso do lātice não aumentou a eficiēncia experimental.

Os valores de $F$ da anālise em látice mostraram variações altamente significativas entre progēnies nos dois tipos de materiais genéticos (matrizes selecionadas e testemunhas) e dois tipos de propagação. 


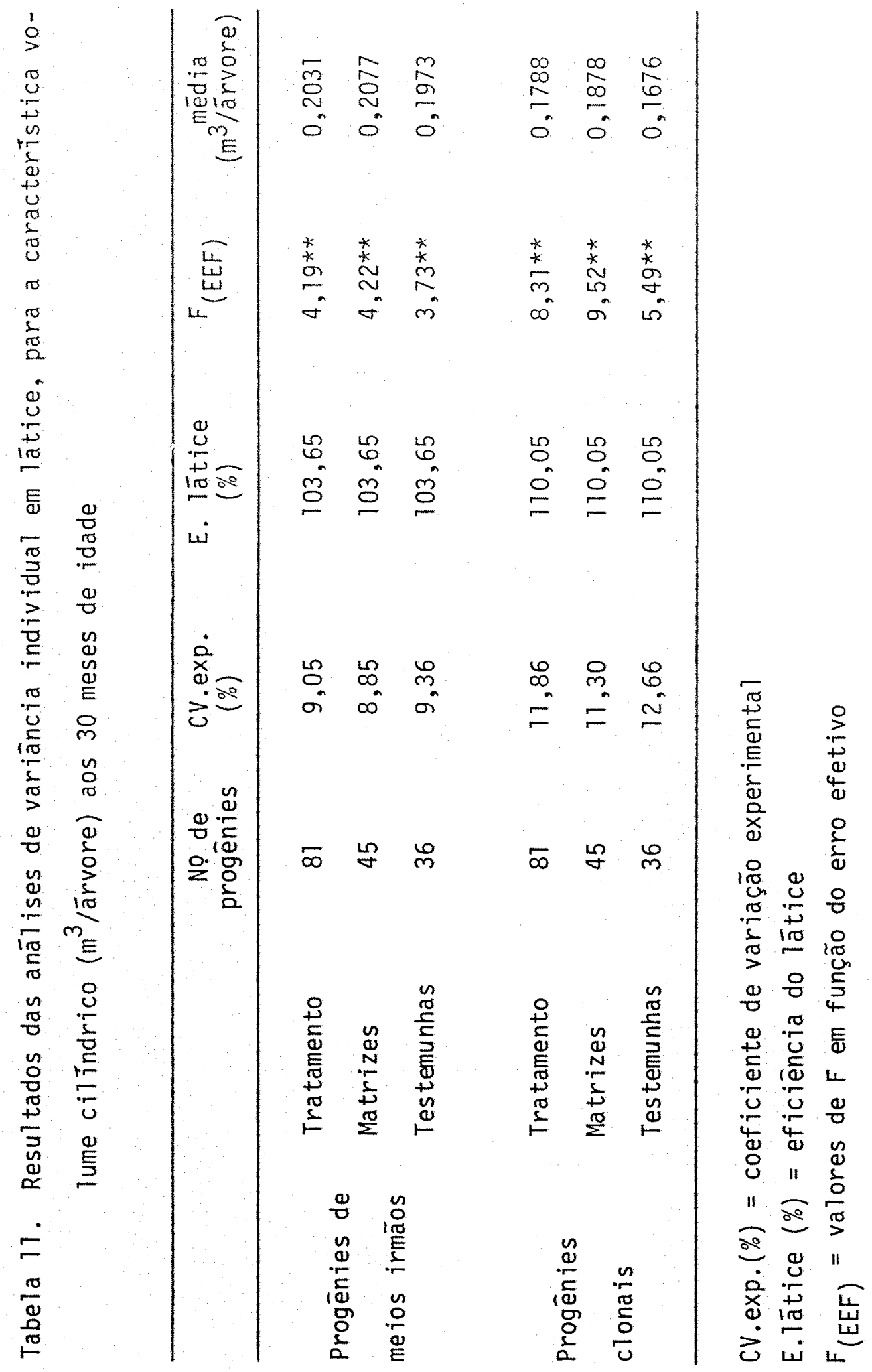


Os valores. comparativos de volume cilindrico aos 30 meses de idade entre matrizes selecionadas e testemunhas, para os dois métodos de propagaçãa, e entre progénies de meios irmãos e progēnies clonais, para as matrizes selecionadas e testemunhas, são apresentados na Tabela 12.

Tabela 12. Valores comparativos de volume cilindrico $\left(\mathrm{m}^{3} /\right.$ ărvore) entre matrizes selecionadas e testemunhas e entre métodos de propagação, aos 30 meses de idade

Progēnies de

meios irmãos

Matrizes selecionadas ( 45 progénies)

0,2077

Testemunhas (36 progēnies)

0,1973

Diferença (\%)

5,27

Progēnies

Matrizes selecionadas ( 45 progēnies)

0,1878

Testemunhas (36 progēnies)

0,1676

clona is

Diferença (\%)

12,05

Matrizes selecionadas

- Progēnies de meios irmãos

0,2077

Progénies clonais

0,1878

(45 progènies)

Diferença (\%)

10,60

Testemunhas

(36 progēnies)

Progēnies de meios irmãos

0,1973

Progēnies clonais

0,1676

Diferença (\%)

17,72 
Observa-se que as matrizes selecionadas são superiores às testemunhas, sendo essa diferença maior em progênies clonais do que em progēnies de meios irmãos. 0 ganho real para volume cilîndrico $\overline{\mathrm{e}}$ maior do que para altura da planta e diâmetro, por ser uma característica composta, sendo os valores mais compativeis com os ganhos esperados com a se1eção. Como foi verificado para as caracteristicas altura e diāmetro, o teste de progénies clonais mostrou maior efetividade na seleção do que 0 teste de progênies de meios irmãos.

0 ganho em progēnies de meios irmãos refere-se à seleção em apenas um sexo, uma vez que as sementes utilizadas foram polinizadas ao acaso pela população. Se as mesmas matrizes selecionadas fossem instaladas no pomar de sementes, o ganho poderā ser em princípio duplicado. Os resultados de ganho real observados são preliminares e não refletem ainda a efetividade da seleção.

Quanto ao método de propagação verificou-se atē a idade de avaliação, uma superioridade das progēnies de meios irmãos em relação às progēnies clonais, tanto para matrizes selecionadas como para testemunhas. Resultado semelhante foi encontrado por BERTOLOTI (1986), com Eucatyptus grandis aos 2 anos de idade, onde os clones mostraram desenvolvimento inferior em relação às sementes comerciais.

0 menor desenvolvimento verificado na propagação vegetativa poderia ser explicado pela diferença na qualidade fisiológica das mudas propagadas por estaquia em relação às obtidas por sementes, mesmo tendo as matrizes selecionadas um bom potencial genético. As mudas propagadas por estaquia apresentaram um sistema radicular menos desenvolvido do que 
as mudas obtidas por sementes, de acordo com os resultados encontrados por FRAMPTON JR. e MACKEAND (1987) e por Mackeand e Wisniewski (1982), citados por FRAMPFON JR. e MACKEAND (1987), em plāntulas micropropagadas de Pinue taeda. Ainda, a idade fisiológica das estacas obtidas de material adulto pode produzir crescimento mais lento, conforme relatados por RAUTER (1982) e por ZOBEL e TALBERT (1984). BURDON (1982) cita que o efeito de maturação progressiva poderia afetar a performance do clone, de forma que a mesma seria diferente entre a fase juvenil e fase adulta.

MORA (1986) observou uma associação entre o clone que apresentou maior crescimento e a presença de raīzes terciārias e quaternārias que, provavelmente, foram as responsāveis pela major absorção de àgua e nutrientes. Observou, tambēm a ausência de raìz pivotante em mudas propagadas por estaquia.

0 tipo do sistema radicular influi grandemente no desenvolvimento da planta, conforme foi encontrado para diversas espēcies de Eutypgus por KREJCI, MARTINS e LOURENÇO (1986). Estes autores verificaram que o Eucalyptus pelizta apresentou melhor arquitetura radicular, devendo ser uma espécie mais plästica em termos de utilização en reflorestamento. 0 Eucalyptus grandis e o Eucalyptus cloesiana foram espécies que apresentaram o sistema radicular menos desenvolvido em profundidade, sendo as mais sensiveis às condições adversas do solo. 0 Eucalyptus citriodora apresentou um bom desenvolvimento da raīz pivotante, com raízes laterais restritas, sendo uma espēcie oue suporta melhor o dēficit hïdrico e mostrou baixo indice de crescimento e pouca resposta a niveis crescentes de adubação. 
Considerando-se que as progénies de meios irmãos e as progénies clonais nas testemunhas deveriam ser iguais, a diferença observada entre elas de $17,72 \%$ em volume cilindrico, aos 30 meses de idade, representa o efeito da qualidade da muda quando propagada vegetativamente. Jā para as matrizes selecionadas a diferença entre as progénies de meios irmãos e as progénies clonais foi de $10,60 \%$ mostrando que o efeito da fisiologia diferenciada da muda por sementes e por estaca pode ter sido compensado pelo efeito da variāncia genética não aditiva na propagação vegetativa.

4.2. Resultados das Anālises das Variāncias Conjuntas para as Características de Crescimento Envolvendo Mëtodos de Propagação

Os resultados das anālises conjuntas envolvendo métodos de propagação para as características altura, DAP e volume cilíndrico aos 30 meses de idade, estão apresentadas na Tabela 13.

Os valores de $F$ obtidos nas anālises conjuntas foram altos para todas as caracterīsticas, mostrando variações significativas entre progēnies, tanto para matrizes selecionadas como para testemunhas.

Os efeitos de métodos de propagação tambēm foram altamente significativos para as características altura, DAP e volume cilindrico, co mo pode ser verificado pelos valores de $F$ nas anālises conjuntas. Este fato demonstra que as progēnies comportam-se de maneira diferente quando pro pagadas por sementes ou por estaquia até os 30 meses de idade. As mudas propagadas por estaquia apresentaram um incremento inicial menor, comparados 


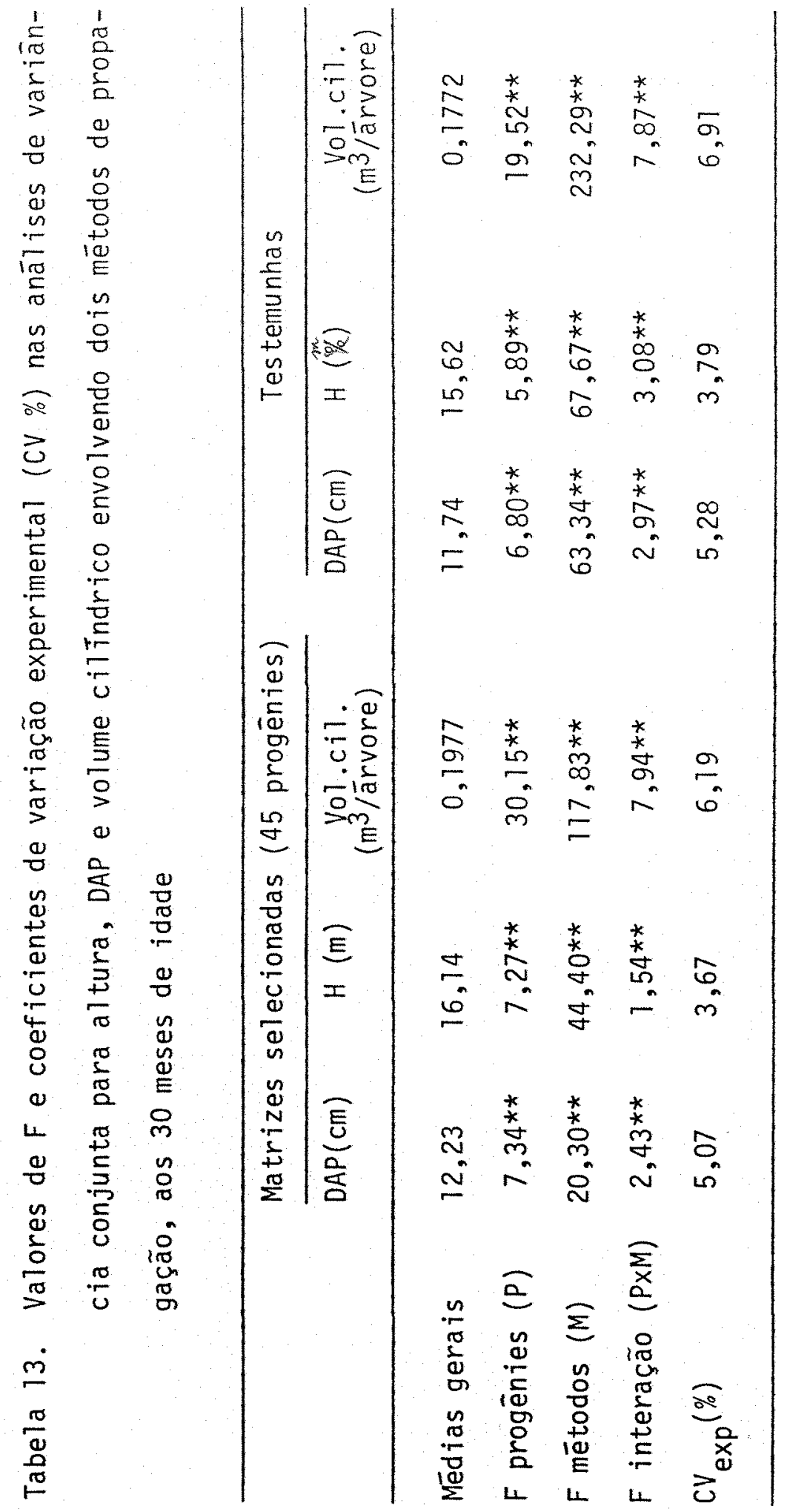


às mudas obtidas por sementes, o que poderia explicar as variações entre os dois métodos de propagação.

os incrementos médios anuais (IMA) em $\mathrm{m}^{3} / \mathrm{ha} /$ ano calculados, levando em consideração o nümero médio de plantas existentes aos 30 meses de idade, estão na Tabela 14 .

Tabela 14. Incremento mëdio anual. (IMA) en volume cilindrico $\left(\mathrm{m}^{3} / \mathrm{ha} / \mathrm{ano}\right)$ aos 30 meses de idade, para progénies de meios irmãos e clonais

\begin{tabular}{cc}
\hline $\begin{array}{l}\text { Progēnies de } \\
\text { meios irmãos }\end{array}$ & $\begin{array}{c}\text { Progēnies } \\
\text { clonais }\end{array}$ \\
\hline IMA $\left(\mathrm{m}^{3} / \mathrm{ha} / \mathrm{ano}\right)$ & IMA $\left(\mathrm{m}^{3} /\right.$ ha $/$ ano $)$
\end{tabular}

Matrizes selecioriadas
(45 progènies)
89,08
71,53

Testemunhas

(36 progēnies)

85,67

59,4

0 incremento médio anual (IMA) obtido em matrizes selecionadas, propagadas atravēs de sementes, foi de $89,08 \mathrm{~m}^{3} / \mathrm{ha} / \mathrm{ano}$. Essas matrizes quando propagadas por estaquia apresentaram um incremento médio de $71,53 \mathrm{~m}^{3} / \mathrm{ha} /$ ano. A diferença na produtividade foi de $24,54 \%$ a menos para os clones, que apresentaram um menor desenvolvimento e maior porcentagem de falhas, como foi apresentado anteriormente.

Para as testemunhas, a diferença de produtividade entre pro gēnies de meios irmãos e progênies clonais foi de $44,13 \%$, valor muito 
superior em relaçâo às matrizes selecionadas. A diferença no incremento médio anual entre matrizes selecionadas e testemunhas foi de $3,98^{\circ}$ para propagação por sementes e de $20,34 \%$ para propagação clonat.

Para a interação de progênies $x$ métodos de propagação, os valores de $F$ obtidos na anālise conjunta tambēm foram significativos para todas as caracteristicas estudadas, o que evidencia diferentes comportamentos das progénies em cada um dos métodos de propagação. As melhores progénies não foram as mesmas quando propagadas por sementes ou por estaquia, para as características avaliadas.

Conforme VENCOVSKY (1977), o valor fenotipico dos genitores nem sempre é reproduzido integralmente nos descendentes. Segundo o autor, em plantas panmîticas onde a multiplicação é feita por cruzamento, o genōtipo dos descendentes não dependem sō do indivĩduo selecionado, mas também do genōtipo daquele indivĩduo com o qual ele foi cruzado. A propagação vegetativa permite a exploração da variabilidade genētica total e perpetua os genótipos superiores sem diluir o seu potencial genético (THULIN, 1969), enquanto que nas progénies de meios irmãos somente a variāncia genētica aditiva é utilizada. Os componentes de interação, segundo VENCOVSKY (1978), è devido à diferença de variabilidade genētica do material dentro dos indivíduos e a falta de correlação entre material de um ambiente para o outro.

Algumas matrizes apresentaram um melhor desenvolvimento quando propagadas por sementes, outras foram melhores quando propagadas por estaquia e ainda existem algumas que mostraram o mesmo comportamento em ambos os métodos de propagação. Este fato sugere que num programa de 
melhoramento, deve-se levar en consideração o método de propagação, uma vez que a seleção dos methores clones pode não ser adequada para produção e utilização de sementes. As progennies de meios irmãos mostram comportamento diferenciado em relação às progénies clonais por serem função dos ge nes aditivos da população; e nas progénies clonais, além dos genes aditivos haveria os genes não aditivos. As matrizes que são altamente heterozigotas e heteróticas teriam um comportamento superior como clone e inferior como progénies de sementes. Conforme cita VENCOVSKY (1987), na reprodução por sementes é necessāria a obtenção de genōtipos superiores ou indivĩduos que sejam capazes de deixar descendentes tambēm com fenōtipos superiores. Anon (1980), citado por BURDON (1982), afirma que a avaliação dos clones parece ser pouco utilizada como ferramenta de medida de valores reprodutivos das ārvores matrizes, embora pareça ser vantajosa para caracterīsticas de alta herdabilidade como a densidade bāsica em Pinus taeda.

Para as testemunhas, encontrou-se tambēm valores de $F$ bastante semelhantes às matrizes selecionadas em todas as características estudadas, tanto entre progēnies como entre métodos de propagação, assim como para interação, que foram altamente significativos. Porém os valores de F progēnies encontrados foram menores para testemunhas em relação às matrizes selecionadas, enquanto que $F$ métodos e $F$ interação mētodos $x$ progēnies foram maiores para todas as caracteristicas. 0 maior valor de $F$ progēnies para material selecionado em relação às testemunhas é devido à baixa herdabilidade do carāter que, para o primeiro caso, faz com que se tenha progènies altamente superiores atē progēnies bem inferiores. Para testemunhas, as progénies tendem para a média da população. 
Os coeficientes de variação experimental apresentaram valores baixos para todas as caracteristicas mostrando boas precisões para anā Tise estatistica.

As médias ajustadas de altura, DAP e volume cilindrico das matrizes selecionadas, colocadas em ordem decrescente tanto para progénies de meios irmãos como para progénies clonais, estão na Tabela 15.

Observa-se que algumas matrizes mudaram de posição quando propagadas por sementes ou por estaca e outras permaneceram na mesma posição. Para a característica altura, a matriz 77 ficou na segunda posição quando propagada por sementes, passou para a $26^{\text {a }}$ posição quando propagada vegetativamente. Já a matriz 64 mostrou o comportamento inverso, ou seja, da 31 a posição passou para a 2 a posição, respectivamente, quando propagada por sementes e por estaca.

Ainda para a caracteristica altura, a matriz 70 manteve a primeira posição, tanto na propagação por semente como por estaca. Essas variações de posições ocorreram tambëm para a caracterīstica DAP e volume cilīndrico. A matriz 69 g̣ue ocupou a primeira posição nas duas caracterîsticas quando propagadas por sementes, passou para a $17^{\mathrm{a}}$ e $20^{\mathrm{a}}$ posição, respectivamente para DAP e volume cilindrico, quando propagada por estaca. Outras matrizes mostraram um comportamento inverso, ou atē mesmo apresentaram um bom desenvolvimento em ambos os métodos de propagação. Essas tendéncias podem ser melhor visualizadas na Figura 1 , onde os volumes cilindricos individuais de algumas progēnies foram colocados nos dois mētodos de propagação. 
Tabela 15. Médias ajustadas de altura, DAP e volume cilindrico das 45 matrizes selecionadas aos 30 meses de idade e ordenadas em posições decrescentes

\begin{tabular}{|c|c|c|c|c|c|c|c|c|c|c|c|c|}
\hline \multirow{3}{*}{$\begin{array}{l}\text { Caracte- } \\
\text { ristica } \\
\text { Propa- } \\
\text { gaçáo } \\
\text { Posição }\end{array}$} & \multicolumn{4}{|c|}{ Altura } & \multicolumn{4}{|c|}{ DAP } & \multicolumn{4}{|c|}{ vol. cil. } \\
\hline & \multicolumn{2}{|c|}{ Semente } & \multicolumn{2}{|c|}{ Estaca } & \multicolumn{2}{|c|}{ Semente } & \multicolumn{2}{|c|}{ Estaca } & \multicolumn{2}{|c|}{ Semente } & \multicolumn{2}{|c|}{ Estaca } \\
\hline & $\begin{array}{c}\text { NQ } \\
\text { matriz }\end{array}$ & $z(m)$ & $\begin{array}{c}\text { No } \\
\text { matriz }\end{array}$ & $2(m)$ & $\begin{array}{c}\text { No } \\
\text { matriz }\end{array}$ & $z(\mathrm{~cm})$ & $\begin{array}{c}\text { Nọ } \\
\text { matriz }\end{array}$ & $z(\mathrm{~cm})$ & $\begin{array}{c}\text { No } \\
\text { matriz }\end{array}$ & $\left(m^{3} / a r v_{r}\right)$ & $\begin{array}{l}\text { No } \\
\text { matriz }\end{array}$ & $\left(m^{3} / a r v.\right)$ \\
\hline 1 & 70 & 17,37 & 70 & 18,01 & 69 & 13,54 & 70 & 14,54 & 69 & 0,2543 & 70 & 0,3053 \\
\hline 2 & 77 & 17,33 & 64 & 17,49 & 56 & 13,38 & 51 & 13,54 & 70 & 0,2433 & & 0,2531 \\
\hline 3 & 66 & 17,29 & 51 & 17,46 & 70 & 13,32 & 74 & 13,49 & 56 & & 64 & 0,2485 \\
\hline 4 & 56 & 17,23 & 56 & 16,99 & 74 & 13,14 & 64 & 13,41 & 74 & 0,2375 & 74 & 0,2366 \\
\hline 5 & 69 & 17,07 & 80 & 16,96 & 77 & 13,05 & 56 & 13,28 & 66 & 0,2374 & 56 & 0,2357 \\
\hline 6 & 47 & 16,95 & 47 & 16,74 & 47 & 13,04 & 45 & 13,23 & 77 & 0,2344 & 45 & 0,2338 \\
\hline 7 & 51 & 16,93 & 66 & 16,67 & 76 & 13,02 & 47 & 13,09 & 76 & 0,2328 & 81 & 0,2383 \\
\hline 8 & 73 & 16,85 & 59 & 16,67 & 66 & 12,94 & 81. & 13,06 & 47 & 0,2309 & 47 & 0,2260 \\
\hline 9 & 81 & 16,84 & 60 & 16,53 & 80 & 12,94 & 44 & 12,98 & 80 & 0,2273 & 80 & 0,2229 \\
\hline 10 & 40 & 16,84 & 62 & 16,52 & 52 & 12,89 & 80 & 12,86 & 73 & 0,2253 & 44 & 0,2161 \\
\hline 11 & 37 & 16,80 & 74 & 16,49 & 78 & 12,86 & 50 & 12,66 & 78 & 0,2245 & 66 & 0,2105 \\
\hline 12 & 50 & 16,73 & 45 & 16,32 & 73 & 12,82 & 62 & 12,63 & 51 & 0,2233 & 62 & 0,2100 \\
\hline 13 & 79 & 16,72 & 71 & 16,28 & 81 & 12,71 & 60 & 12,60 & 52 & 0,2226 & 50 & 0,2072 \\
\hline 14 & 78 & 16,70 & 73 & 16,25 & 50. & 12,68 & 66 & 12,59 & 37 &, 2193 & 60 & 0,2060 \\
\hline 15 & 59 & 16,69 & 75 & 16,25 & 45 & 12,56 & 79 & 12,56 & 64 & 0,2789 & 79 & 0,2051 \\
\hline 16 & 80 & 16,65 & 44 & 16,22 & 46 & 12,56 & 42 & 12,49 & 81 & 0,2181 & 68 & 0,2022 \\
\hline 17 & 44 & 16,64 & 50 & 16,16 & 40 & 12,51 & 69 & 12,42 . & 79 & 0,2191 & 42 & 0,2019 \\
\hline 18 & 75 & 16,61 & 81 & 16,15 & 51 & 12,50 & 71 & 12,41 & 50 & 0,2172 & 71 & 0,1980 \\
\hline 19 & 74 & 16,59 & 68 & 16,09 & 64 & 12,49 & 68 & 12,36 & 45 &, 2135 & 46 & 0,1966 \\
\hline 20 & 76 & 16,58 & 79 & 16,08 & 37 & 12,48 & 46 & 12,33 & 40 & 0,2133 & 69 & 0,1956 \\
\hline 21 & 60 & 16,53 & 37 & 16,04 & 79 & 12,47 & 78 & 12,25 & 46 & 0,2103 & 78 & 0,1954 \\
\hline 22 & 46 & 16,52 & 42 & 15,96 & 60 & 12,45 & 37 & 12,10 & 60 & 0,2099 & 37 & 0,1865 \\
\hline 23 & 45 & 16,50 & 46 & 15,95 & 44 & 12,37 & 39 & 12,03 & 44 & 0,2067 & 76 & 0,1821 \\
\hline 24 & 53 & 16,47 & 40 & 15,95 & 59 & 12,37 & 76 & 12,00 & 71 & 0,2064 & 39 & 0,1807 \\
\hline 25 & 58 & 16,33 & 78 & 15,91 & 75 & 12,34 & 48 & 11,90 & 68 & 0,2049 & 73 & 0,1799 \\
\hline 26 & 52 & 16,30 & 77 & 15,83 & 58 & 12,31 & 73 & 11,81 & 62 & 0,2031 & 59 & 0,1768 \\
\hline 27 & 49 & 16,29 & 58 & 15,74 & 71 & 12,30 & 54 & 11,67 & 59 & 0,2031 & 75 & 0,1739 \\
\hline 28 & 62 & 16,28 & 76 & 15,74 & 39 & 12,30 & 65 & 11,64 & 75 & 0,2016 & 48 & 0,1735 \\
\hline 29 & 38 & 16,27 & 69 & 15,67 & 62 & 12,29 & 59 & 11,57 & 58 & 0,2004 & 58 & 0,1679 \\
\hline 30 & 68 & 16,23 & 39 & 15,67 & 68 & 12,27 & 75 & 11,57 & 39 & 0,1973 & 54 & 0,1679 \\
\hline 31 & 64 & 16,19 & 49 & 15,58 & 57 & 12,19 & 58 & 11,57 & 63 & 0,1968 & 65 & 0,1670 \\
\hline 32 & 48 & 16,12 & 54 & 15,52 & 63 & 12,19 & 61 & 11,45 & 48 & 0,1945 & 40 & 0,1651 \\
\hline 33 & 39 & 16,10 & 48 & 15,49 & 48 & 12,14 & 67 & 11,37 & 42 & 0,1 & 8 & 0,1592 \\
\hline 34 & 43 & 16,00 & 38 & 15,42 & 43 & 12,11 & 53 & 11,29 & 43 & 0,1 & 61 & 0,1557 \\
\hline 35 & 54. & 15,97 & 55 & 15 & 49 & 12,01 & 77 & 11,26 & 49 & 0,1 & 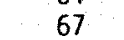 & 0,1530 \\
\hline 36 & 71 & 15,94 & 53 & 15, & 38 & 11,87 & 40 & 11,24 & 54 & 0,1875 & 53 & 0,1525 \\
\hline 37 & 63 & 15,87 & 41 & 15, & 53 & 11,85 & 41 & 11,16 & 20 & 0,1871 & & 0,1505 \\
\hline 38 & 57 & 15,86 & 65 & 14 , & 54 & 11,78 & 43 & 11,15 & 57 & 0,1 & 43 & 0,1503 \\
\hline 39 & 41 & 15,81 & 61 & 14,9 & 41 & 11,69 & 57 & 11,13 & 53 & 0,1859 & 41 & 0,1493 \\
\hline 40 & 42 & 15,60 & 72 & 14, & 61 & 11,67 & 52 & 10,95 & 65 & 0,1794 & 38 & 0,1445 \\
\hline 41 & 55 & 15,59 & 63 & 14,8 & 42 & 11,62 & 63 & 10,94 & 41 & 0,1762 & 57 & 0,1367 \\
\hline 42 & 72 & 15,51 & 67 & 14, & 72 & 11,60 & 38 & 10,84 & 61 & 0,1757 & 72 & 0,7366 \\
\hline 43 & 61 & 15,48 & 43 & 14,55 & 67. & 11,59 & 72 & 10,63 & 72 & 0,1745 & 52 & 0,1354 \\
\hline 44 & 67 & 15,23 & 52 & 14, & 65 & 11,56 & 55 & 10,55 & 67 & 0,1709 & 49 & 0,1351 \\
\hline 45 & 65 & 14,84 & 57 & 14, & 55 & 11,03 & 49 & 10,4 & 55 & 0,1622 & 55 & 0,1350 \\
\hline
\end{tabular}


PROGÊMES DE MEIOS IRMÃOS

PROGENES CLONAIS

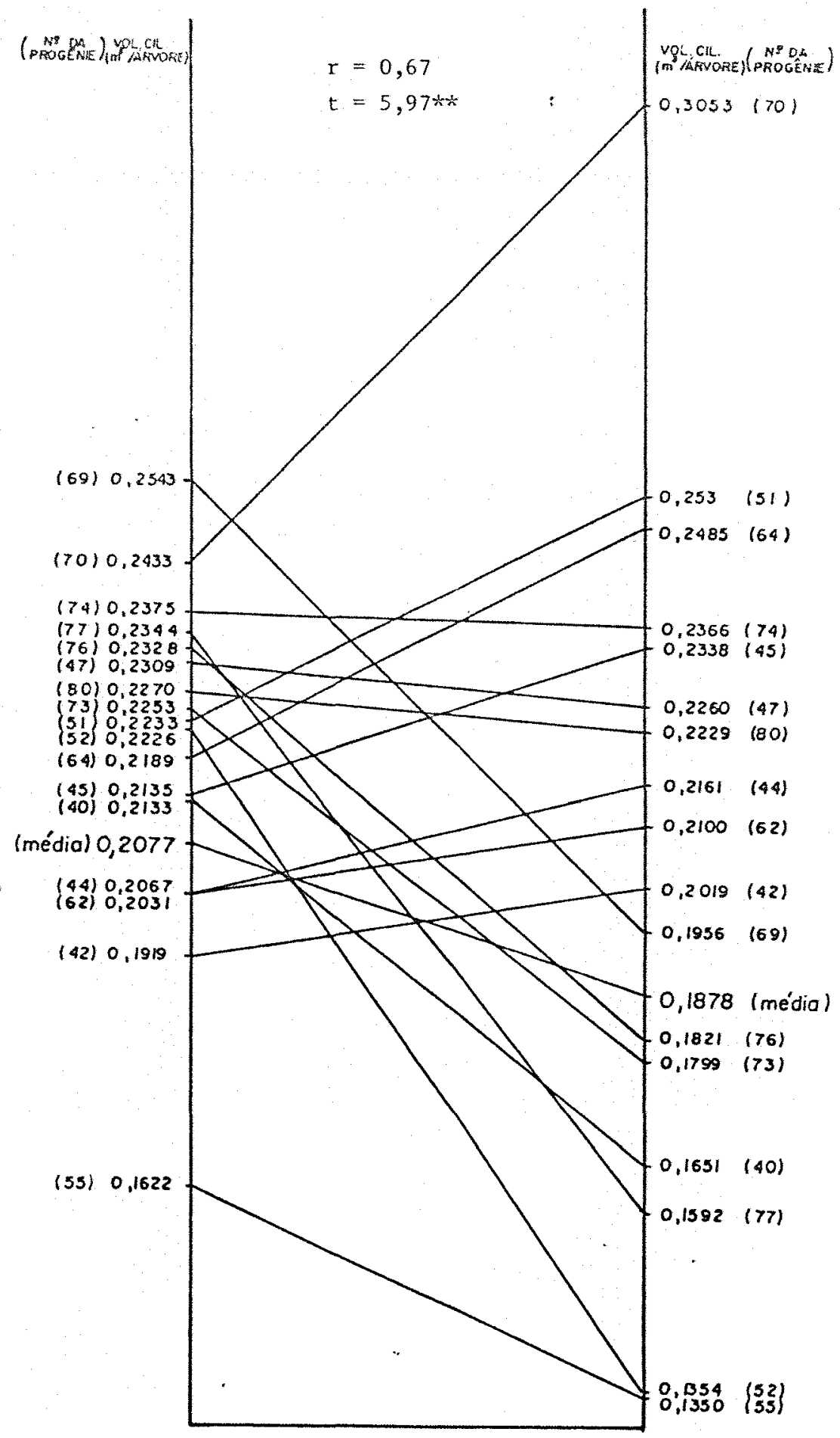

Figura 1 - Comportamento de algumas progēnies de Eucalyptus grandis (Hi11) Maiden em volume cillíndrico ( $\mathrm{m}^{3} /$ ărvore) nos doís métodos de propagaçāo aos 30 meses de idade. Foram utilizadas progēnies que mantiveram posiçōes estáveis e aquelas con diferença de 10 pontos na sua posiçāo relativa. $r=$ coeficiente de correlaçāo ao ní vel de mëdias entre progēnies de meios irmāos e progēnies clonais, para as 45 ärvores selecionadas, $t=$ teste de significāncia de $r$. 
0 comportamento diferencial demonstrado pelas matrizes fren te ao método de propagação deve ser utilizada para obtenção de progénies especificas para o programa de melhoramento sexuado ou assexuado. Este fato evidencia a importância da implantação do teste de progênies de meios irmãos e testes clonais com as mesmas matrizes, uma vez que os clones podem não ter correlação com o valor reprodutivo ou produção de sementes.

A propagação por estaca, apesar de apresentar em média um desenvolvimento inferior à propagação por sementes, para todas as características, mostrou alguns clones excepcionais, com desenvolvimento inclusive superior a qualquer progênie de meios irmãos. Para a característica a)tura, os clones 70,64 e 51 foram superiores a todas as progénies de meios irmãos. As mesmas situações foram verificadas nos clones 70 e 51 para DAP e clone 70 para o volume cilindrico. Provavelmente os clones com comportamento muito superior às sementes devem ter sua superioridade fenotîpica devido aos genes não aditivos.

Os piores resultados de crescimento foram também verificados para clones, o que pode explicar melhor as médias inferiores em relação às progénies de meios irmãos. A amplitude da variação para matrizes propagadas vegetativamente foi muito maior do que para matrizes propagadas por sementes. Por exemplo, para a característica altura, houve variação de $14,84 \mathrm{~m}$ a $17,37 \mathrm{~m}$, respectivamente para as matrizes 65 e 70 , na propagação por sementes enquanto que na propagação por estaquia variou de $14,00 \mathrm{~m}$ a $18,01 \mathrm{~m}$, respectivamente para as matrizes 57 e 70 . 
0 coeficiente de correlação entre progēnies de meios irmãos e progénies clonais foi relativamente alto $(0,67)$, o que mostra a existência de certa correlação ao nivel de médias. Apesar disso, o mais importante é o fato de que algumas matrizes não seguem esta tendéncia.

Estes resultados indicam que no programa de propagação vegetativa em escala comercial é imprescindivel que os testes clonais sejam instalados para que se possa selecionar os melhores clones efetivamente e com isso obter os melhores ganhos possiveis. Segundo a recomendação de RAUTER. (1982), antes de envolver-se em um programa de propagação vegetativa em larga escala, deve haver garantia de cue o material selecionado manterā a sua superioridade atē a fase de exploração.

4.3. Estimativa de Parāmetros Genéticos

4.3.1. Estimativa de variāncias genéticas e não genēticas para as caracteristicas altura, DAP e volume cilindrico

As estimativas de variāncias genēticas e fenotīpicas para as características altura, diāmetro e volume cilinndrico, tanto para progēnies de meios irmãos como para progēnies clonais, aos 30 meses de idade estão expressos na Tabela 16.

Essas estimativas, obtidas a partir dos componentes de variāncia nas anālises individuais, foram utilizadas para se calcular os coe ficientes de variação e herdabilidade em cada um dos métodos de propagação e material genētico. 
Tabela 16. Estimativa de variāncias genēticas dentro de progēnies $\left(\sigma^{2} d\right)$, entre progénies $\left(\sigma^{2} p\right)$, do erro $\left(\sigma^{2} e\right)$, fenotipica $\left(\sigma^{2} F\right)$ e a relação $\sigma^{2} d / \sigma^{2} p$, para as caracteristicas altura, DAP e volume cilindrico, aos 30 meses de idade

\begin{tabular}{|c|c|c|c|c|c|}
\hline \multirow{2}{*}{$\begin{array}{l}\text { Caracte- } \\
\text { risticas }\end{array}$} & \multirow{2}{*}{ Parāmetro } & \multicolumn{2}{|c|}{ Progēnies de meios irmãos } & \multicolumn{2}{|c|}{ Progēnies clonais } \\
\hline & & $\begin{array}{c}\text { Matrizes } \\
\text { selecionadas }\end{array}$ & Testemunhas & $\begin{array}{c}\text { Matrizes } \\
\text { selecionadas }\end{array}$ & Testemunhas \\
\hline \multirow{5}{*}{$\begin{array}{l}\text { Al tura } \\
(\mathrm{m})\end{array}$} & $\sigma^{2} d$ & 2,9879 & 3,0649 & 1,2476 & 1,4150 \\
\hline & $\sigma^{2} \mathrm{e}$ & 0,0077 & 0,0036 & 0,2388 & 0,2071 \\
\hline & $\sigma^{2} p$ & 0,2182 & 0,0607 & 0,5774 & 0,8420 \\
\hline & $\sigma^{2} F$ & 3,2138 & 3,1292 & 2,0638 & 2,2641 \\
\hline & $\sigma^{2} d / \sigma^{2} p$ & 13,69 & 50,48 & 2,16 & 2,20 \\
\hline \multirow{5}{*}{$\begin{array}{l}\text { DAP } \\
(\mathrm{cm})\end{array}$} & $\sigma^{2} d$ & 3,8005 & 2,7114 & 1,7718 & 1,8158 \\
\hline & $\sigma^{2} \mathrm{e}$ & 0,0000 & 0,0000 & 0,2464 & 0,2238 \\
\hline & $\sigma^{2} p$ & 0,2135 & 0,2072 & 0,7151 & 0,5624 \\
\hline & $\sigma^{2} F$ & 3,8856 & 2,9065 & 2,7314 & 2,6019 \\
\hline & $\sigma^{2} d / \sigma^{2} p$ & 17,80 & 13,09 & 2,48 & 3,23 \\
\hline \multirow{5}{*}{$\begin{array}{l}\text { Vol.cil. } \\
\text { (m3/ärvore) }\end{array}$} & $\sigma^{2} d$ & 0,004607 & 0,003550 & 0,002097 & 0,001721 \\
\hline & $\sigma^{2} \mathrm{e}$ & 0,000000 & 0,000000 & 0,000205 & 0,000234 \\
\hline & $\sigma^{2} p$ & 0,000363 & 0,000307 & 0,001278 & 0,000674 \\
\hline & $\sigma^{2} F$ & 0,004831 & 0,003832 & 0,003580 & 0,002629 \\
\hline & $\sigma^{2} \mathrm{~d} / \sigma^{2} \mathrm{p}$ & 12,69 & 11,56 & 1,64 & 2,55 \\
\hline
\end{tabular}


Os valores das estimativas de variāncia dentro de progēnies $\left(\sigma^{2}\right.$ d) foram menores nos clones em relação às progēnies de meios irmãos, em todas as caracterîsticas. Estas situações foram verificadas nas matrizes selecionadas e nas testemunhas, nos dois métodos de propagação. Os clones, por serem geneticamente idēnticos à planta mãe, apresentaram maior homogeneidade dentro de progénies, o que resultou também na menor variância fenotipica.

Quando se observa a variāncia entre progênies $\left(\sigma^{2} p\right)$ verifica-se uma outra tendēncia, ou seja, os valores encontrados, tanto para matrizes selecionadas como para testemunhas, foram sempre maiores nas progēnies clonais em relação às progēnies de meios irmãos.

A relação entre a variância dentro de progēnies e a variância genētica entre progēnies $\left(\sigma^{2} d / \sigma^{2} p\right)$ se apresenta como um parāmetro indicador do sistema reprodutivo. FONSECA (1982) sugeriu que nas plantas alógamas essa relação tenderia para valores maiores que dez. Para todas as características analisadas os valores da relação entre as variāncias dentro e entre progēnies $\left(\sigma^{2} d / \sigma^{2} p\right)$ foram sempre superiores a 10 nas progēnies de meios irmãos, o que confirma a característica a lógama da espécie quando propagada por sementes. Resultado semelhante foi encontrado também por PATINO-VALERA (1986) em testes de progēnies de Eucalyptus saligna.

Por outro lado, essa mesma relação $\left(\sigma^{2} d / \sigma^{2} p\right)$ nas progēnies clonais apresentaram valores muito baixos em todas as caracteristicas, demonstrando ser um padrão de tendēncia para plantas de reprodução vegetaviva. 
Na Tabela 16 observa-se ainda influência da seleção nas variāncias entre progēnies $\left(\sigma^{2} p\right)$. Em todas as características estudadas, os valores de variāncia genētica entre progēnies foram ligeiramente maiores em matrizes selecionadas em relação às testemunhas. Entretanto, a relação $\sigma^{2} d / \sigma^{2} p$ mostrou diferentes comportamentos nas caracteristicas. Para a caracteristica altura, em progénies de meios irmãos, essa relação nas testemunhas apresentou valores bem maiores, enquanto que para as caracteristicas DAP e volume cilindrico os valores foram maiores nas matrizes selecionadas.

A variação dentro de progênies de meios irmãos contēm (considerando-se desprezível a variāncia epistātica):

$$
\sigma^{2} d=(3 / 4) \sigma^{2} A+\sigma^{2} N A+\sigma^{2} d a
$$

onde:

$$
\begin{aligned}
& \sigma^{2} A=\text { variāncia genética aditiva } \\
& \sigma^{2} N A=\text { variāncia genētica não aditiva } \\
& \sigma^{2} d a=\text { variância dentro ambiental }
\end{aligned}
$$

Em se tratando de propagação de plantas alógamas, o componente de variāncia mais importante é a contribuição devido aos efeitos adi tivos dos genes (PATERNIANI, 1966, FALCONER, 1981; VENCOVSKY, 1978) e 0 melhoramento pela seleção depende da presença suficiente da variāncia genética aditiva (ELDRIDGE, 1977). Por outro lado, para a propagação vegetativa, quanto maior o efeito genético não aditivo maior será o potencial para o ganho genético, conforme relatado por MACKEAND e WEIR (1984) e por Fielding (1970), citado por ZOBEL e TALBERT, 1984. 
Uma possibilidade de se estimar a variāncia genética não aditiva è através da utilização da variāncia dentro de clones que contém apenas a variāncia ambiental dentro da parcela $\left(\sigma^{2} d a\right)$. Considerando-se que os experimentos foram implantados em condições semelhantes, a estimativa da variāncia não aditiva nas progénies de meios irmãos fica:

$$
\sigma^{2} N A=\sigma^{2} d-(3 / 4) \sigma^{2} A-\sigma^{2} d a
$$

0s resultados encontrados estão na Tabela 17:

Tabela 17. Estimativas das variāncias genēticas não aditivas $\left(\sigma^{2} N A\right)$ em progênies de meios irmãos para caracterīsticas de crescimento, aos 30 meses de idade

\begin{tabular}{llclll}
\hline \multirow{2}{*}{$\begin{array}{l}\text { Caracteris- } \\
\text { ticas }\end{array}$} & \multicolumn{2}{c}{ Matrizes selecionadas } & & \multicolumn{2}{c}{ Testemunhas } \\
\cline { 2 - 3 } & $\sigma^{2} \mathrm{NA}$ & $\frac{\sigma^{2} \mathrm{~A}}{\sigma^{2} \mathrm{~A}+\sigma^{2} \mathrm{NA}}$ & & $\sigma^{2} \mathrm{NA}$ & $\frac{\sigma^{2} \mathrm{~A}}{\sigma^{2} \mathrm{~A}+\sigma^{2} \mathrm{NA}}$ \\
\hline Altura & 1,0857 & 0,4460 & 1,4678 & 0,1420 \\
DAP & 1,3882 & 0,3809 & 0,2740 & 0,7515 \\
Vo1. cil. & 0,001421 & 0,5054 & 0,000908 & 0,5749 \\
\hline
\end{tabular}

A relação $\frac{\sigma^{2} A}{\sigma^{2} A+\sigma^{2} N A}$ demonstra a quantidade da variāncia ge nētica aditiva em relação à variāncia genética total. Observa-se que para a característica altura e DAP, nas matrizes selecionadas, a variāncia genética aditiva representa menos da metade da variāncia total. Para a caracterĩstica volume cilindrico o efeito genético aditivo é igual ao efę to genético não aditivo. 
Nas testemunhas, observa-se que hā maior quantidade de variāncia genética aditiva nas características. DAP e volume cilindrico, enquanto que para altura da planta hā menor efeito genético não aditivo. Esse fato evidencia o exposto por Fielding (1970), citado por ZOBEL e TALBERT (1984) onde, para algumas caracteristicas, os ganhos de regeneração por sementes poderão ser grandes, mas para outras que contém quantidades significativas de variāncia não aditiva, os ganhos serão menores em relação à propagação vegetativa.

Essas estimativas das variâncias não aditivas com valores bastante altos não estão coerentes com os resultados obtidos de herdabilidade no sentido amplo, que foram baixos. Isso talvez se deva ao método indireto de estimativa de variāncia não aditiva, que pode estar acumulando erros. Por outro 1ado, como os resultados de variāncia não aditiva foram altos para todas as características e materiais genēticos, deve se levantar a possibilidade de que a variāncia genética não aditiva seja expressiva na população.

A observação dos coeficientes de variação genētica, apresentada na Tabela 18, evidencia melhor as diferentes tendéncias das variāncias nos dois métodos de propagação.

Os coeficientes de variação dentro $\left(\mathrm{CV}_{\mathrm{d}} \%\right)$ para as trēs características foram sempre maiores nas progēnies de meios irmãos, enquanto que os coeficientes de variação entre progēnies $\left(C V_{p} \%\right)$ foram sempre bem maiores nas progēnies clonais. 
Tabela 18. Coeficiente de variação dentro de progénies $\left(\mathrm{CV}_{\mathrm{d}} \%\right)$, entre progénies $\left(C V_{p} \%\right)$ e fenotipicas $\left(C V_{F} \%\right)$ para as caracteristicas estudadas aos 30 meses de idade

\begin{tabular}{|c|c|c|c|c|c|}
\hline \multirow[b]{2}{*}{$\begin{array}{l}\text { Caracte- } \\
\text { riticas }\end{array}$} & \multirow[b]{2}{*}{$\begin{array}{l}\text { Parā- } \\
\text { metro }\end{array}$} & \multicolumn{2}{|c|}{ Progēnies de meios irmãos } & \multicolumn{2}{|c|}{ Progenies clonais } \\
\hline & & $\begin{array}{l}\text { Matrizes } \\
\text { selecio- } \\
\text { nadas }\end{array}$ & Testemunhas & $\begin{array}{l}\text { Matrizes } \\
\text { selecio- } \\
\text { nadas }\end{array}$ & Testemunhas \\
\hline \multirow{3}{*}{ Altura } & $\mathrm{CV}_{\mathrm{d}^{\%}}$ & 10,55 & 10,83 & 7,02 & 7,70 \\
\hline & $\mathrm{CV}_{\mathrm{p}} \%$ & 2,85 & 1,52 & 4,78 & 5,19 \\
\hline & $\mathrm{CV}_{\mathrm{F}} \%$ & 10,94 & 10,95 & 9,04 & 9,74 \\
\hline \multirow{3}{*}{ DAP } & $C V_{d} \%$ & 15,72 & 13,44 & 11,33 & 11,03 \\
\hline & $C V_{p} \%$ & 3,73 & 3,72 & 7,18 & 7,01 \\
\hline & $\mathrm{CV}_{\mathrm{F}} \%$ & 15,90 & 13,92 & 14,03 & 13,69 \\
\hline \multirow{3}{*}{ Vol.cil. } & $C V_{d} \%$ & 32,68 & 30,20 & 24,38 & 24,75 \\
\hline & $C V_{p} \%$ & 9,17 & 8,88 & 19,03 & 15,49 \\
\hline & $\mathrm{CV}_{\mathrm{F}} \%$ & 33,46 & 31,37 & 31,86 & 30,59 \\
\hline
\end{tabular}

De um modo geral a característica al tura apresentou menores valores de coeficientes de variação genética, seguido do DAP. 0 volume cilindrico, por ser uma caracteristica composta, apresentou maiores valores de coeficientes de variação.

Pelos valores dos coeficientes de variação genética expressos na Tabela 18, observa-se uma pequena influēncia da seleção 
estimativas das variāncias, porém sem nenhuma tendéncia para os resultados.

Os coeficientes de variação dentro de parcelas $\left(\mathrm{CV}_{\mathrm{d}} \%\right)$ e entre progēnies $\left(C V_{p} \%\right)$ mostraram valores prōximos entre as matrizes selecionadas e as testemunhas, tanto em progēnies de meios irmãos como em progēnies clonais. No caso de progènies clonais, entretanto, a variāncia dentro é devida apenas à variância ambiental dentro da parcela, uma vez que são propagadas vegetativamente. Portanto, é de se esperar que o coeficiente de variação dentro $\left(\mathrm{CV}_{\mathrm{d}} \%\right)$ para clones seja menor como foi observado na tabela 18. Porém, na fase inicial, a qualidade da muda ligada a aspectos fisiológicos como foi discutido anteriormente, parece influir grandemente na variāncia dentro de progēnies clonais, como mostra a Tabela 19.

Observa-se na Tabela 19 que os coeficientes de variação den tro $\left(\mathrm{CV}_{\mathrm{d}} \%\right)$ para altura e DAP nas progēnies de meios irmãos não mostraram nenhuma tendēncia de diminuição ou de aumento dos valores em função da ida de. Esta situação é verificada tanto nas matrizes selecionadas como nas testemunhas, quando propagadas por sementes. Uma possivel explicação seria a de que ainda não tenha iniciado a competição entre plantas dentro de progēnies no espaçamento utilizado. 0 aumento de variação dentro de parcelas com a idade verificado por PATINO-VALERA (1986) en Eucalyptus saligna Smith se deve ao estabelecimento de competição entre plantas, o que tambēm explicaria a diminuição dos coeficientes de herdabilidade com a idade. 
Tabela 19. Coeficiente de variação dentro de progênies para as caracteristicas altura e DAP nas idades de $12,18,24$ e 30 meses

\begin{tabular}{|c|c|c|c|c|c|}
\hline \multirow[b]{2}{*}{$\begin{array}{l}\text { Caracte- } \\
\text { ristica }\end{array}$} & \multirow[b]{2}{*}{ Idade } & \multicolumn{2}{|c|}{ Progénies de meios irmãos } & \multicolumn{2}{|c|}{ Progēnies clona is } \\
\hline & & $\begin{array}{l}\text { Matrizes } \\
\text { selecio- } \\
\text { nadas }\end{array}$ & Testemunhas & $\begin{array}{l}\text { Matrizes } \\
\text { selecio- } \\
\text { nadas }\end{array}$ & Tes temunhas \\
\hline \multirow{4}{*}{ Altura } & 12 & 12,20 & 10,37 & 13,69 & 13,35 \\
\hline & 18 & 10,44 & 8,57 & 7,88 & 8,27 \\
\hline & 24 & 10,58 & 10,62 & 7,08 & 7,17 \\
\hline & 30 & 10,55 & 10,83 & 7,02 & 7,70 \\
\hline \multirow{4}{*}{ DAP } & 12 & 16,97 & 15,01 & 22,28 & 21,41 \\
\hline & 18 & 14,20 & 12,26 & 12,96 & 12,94 \\
\hline & 24 & 14,72 & 12,91 & 11,11 & 10,77 \\
\hline & 30 & 15,72 & 13,44 & 11,03 & 11,72 \\
\hline
\end{tabular}

Para as progênies clonais foram observadas nittidas tendēncias de diminuição dos valores de coeficientes de variação dentro com a idade, até 30 meses, nas duas caracteristicas. Os coeficientes de variação dentro $\left(\mathrm{CV}_{\mathrm{d}} \%\right)$ para altura e DAP, aos 12 meses de idade, foram maiores nas progēnies clonais. Jā aos 30 meses de idade, houve uma inversão de posição sendo que os valores dos coeficientes de variação dentro das progēnies clonais passaram a ser menores em relação às progēnies de meios irmãos. 
As plantas propagadas vegetativamente por estaņuia apresentaram no inîcio uma variação dentro muito grande, possivelmente influenciadas pela çualidade fisiológica das mudas. Com o desenvolvimento houve uma tendência de uniformização, demonstrando a predomināncia da homogeneidade genética dentro dos clones.

Os coeficientes de variação genética entre progēnies $\left(\mathrm{CV}_{\mathrm{p}} \%\right)$ para as caracteristicas altura e diâmetro estão apresentados na Tabela 20. Tabela 20. Coeficientes de variação genētica entre progēnies $\left(C V_{p} \%\right)$, para as características altura e DAP aos $12,18,24$ e 30 meses de idade

\begin{tabular}{|c|c|c|c|c|c|}
\hline \multirow[b]{2}{*}{$\begin{array}{l}\text { Caracte- } \\
\text { risticas }\end{array}$} & \multirow[b]{2}{*}{$\begin{array}{c}\text { Idade } \\
\text { (meses) }\end{array}$} & \multicolumn{2}{|c|}{ Progēnies de meios irmãos } & \multicolumn{2}{|c|}{ Progenies clona is } \\
\hline & & $\begin{array}{l}\text { Matrizes } \\
\text { selecio- } \\
\text { nadas }\end{array}$ & Tes temunhas & $\begin{array}{l}\text { Matrizes } \\
\text { selecio- } \\
\text { nadas }\end{array}$ & Tes temunhas \\
\hline \multirow{4}{*}{ Altura } & 12 & 3,37 & 2,60 & 6,15 & 8,07 \\
\hline & 18 & 1,71 & 1,52 & 3,64 & 5,22 \\
\hline & 24 & 2,96 & 1,67 & 3,65 & 4,85 \\
\hline & 30 & 2,85 & 1,52 & 4,78 & 5,19 \\
\hline \multirow{4}{*}{ DAP } & 12 & 4,67 & 2,98 & 7,82 & 10,21 \\
\hline & 18 & 4,06 & 2,77 & 5,32 & 6,06 \\
\hline & 24 & 3,83 & 3,35 & 6,52 & 6,35 \\
\hline & 30 & 3,73 & 3,72 & 7,01 & 6,52 \\
\hline
\end{tabular}


A comparação de tendencias do coeficiente de variação entre progēnies $\left(\mathrm{CV}_{\mathrm{p}} \%\right)$ entre idades deve ser efetuada levando-se em consideração os pares de idade de 12 e 24 meses, jā que se referem às medições no mesmo perīodo de crescimento. Usando este critério, verifica-se que o coeficien te de variação entre progénies mostra uma tendéncia de decrēscimo com a idade, tanto para progénies de meios irmãos como para progēnies clonais. Esses dados concordam com os obtidos por KAGEYAMA (1983), que verificou o decrēscimo do coeficiente de variação genētica com a idade para Eucalyptus grandis Hill ex Maiden. Segundo o autor, a anālise da evolução dos diferentes tipos de coeficientes de variação permite discutir fundamentalmente a evolução do coeficiente de herdabilidade.

Um outro ponto colocado pelo mesmo autor è que a alta herdabilidade genética na idade juvenil seria importante para que as ārvores mantivessem a posição competitiva da copa no dossel superior do povoamento a té o inīcio da preparação da ārvore para a reprodução da espécie. Resultado semelhante de decréscimo do coeficiente de variação entre progēnies foi tambëm encontrado por PATINO-VALERA (1986) em Eucalyptus saligna.

Os maiores valores de coeficientes de variação entre progènies foram verificados em testemunhas das progênies clonais, seguindo-se pela ordem decrescente, em matrizes das progênies clonais e matrizes e tes temunhas das progēnies de meios irmãos.

0 coeficiente de variação fenotîpica, resultante das variān cias genëticas entre e dentro de progēnies e das variâncias ambientais, mostrou diferentes resultados entre progēnies de meios irmãos e progênies clonais. Na Tabela 21 estão apresentados os coeficientes de variação 
fenotipica $\left(\mathrm{CV}_{\mathrm{F}} \%\right)$ para as caracteristicas altura e DAP.

Observa-se que as progēnies clonais, tanto para matrizes selecionadas como para testemunhas, apresentaram tendência de diminuição dos coeficientes de variação fenotipica atē os 30 meses de idade.

Tabela 21. Coeficiente de variação fenotipica $\left(C V_{F} \%\right)$ para as caracterîsticas altura da planta e DAP aos $12,18,24$ e 30 meses de idade

\begin{tabular}{|c|c|c|c|c|c|}
\hline \multirow[b]{2}{*}{$\begin{array}{l}\text { Caracte- } \\
\text { risticas }\end{array}$} & \multirow[b]{2}{*}{$\begin{array}{c}\text { Idade } \\
\text { (meses) }\end{array}$} & \multicolumn{2}{|c|}{ Progēnies de meios irmãos } & \multicolumn{2}{|c|}{ Progēnies clona is } \\
\hline & & $\begin{array}{l}\text { Matrizes } \\
\text { selecio- } \\
\text { nadas }\end{array}$ & Testemunhas & $\begin{array}{c}\text { Matrizes } \\
\text { selecio- } \\
\text { nadas }\end{array}$ & Tes temunhas \\
\hline \multirow{4}{*}{ Altura } & 12 & 12,92 & 11,19 & 16,18 & 16,83 \\
\hline & 18 & 10,60 & 8,94 & 9,54 & 10,53 \\
\hline & 24 & 11,13 & 10,91 & 8,54 & 9,17 \\
\hline & 30 & 10,94 & 10,95 & 9,04 & 9,74 \\
\hline \multirow{4}{*}{ DAP } & 12 & 17,81 & 15,73 & 25,21 & 25,62 \\
\hline & 18 & 14,64 & 12,64 & 14,74 & 15,08 \\
\hline & 24 & 15,08 & 13,40 & 13,50 & 13,23 \\
\hline & 30 & 15,90 & 13,92 & 13,69 & 14,03 \\
\hline
\end{tabular}

Em progēnies de meios irmãos os coeficientes de variação fe् notípica não mostraram tendēncias visivveis no decorrer da idade.

Essas tendēncias estão melhor ilustradas na Figura 2. 

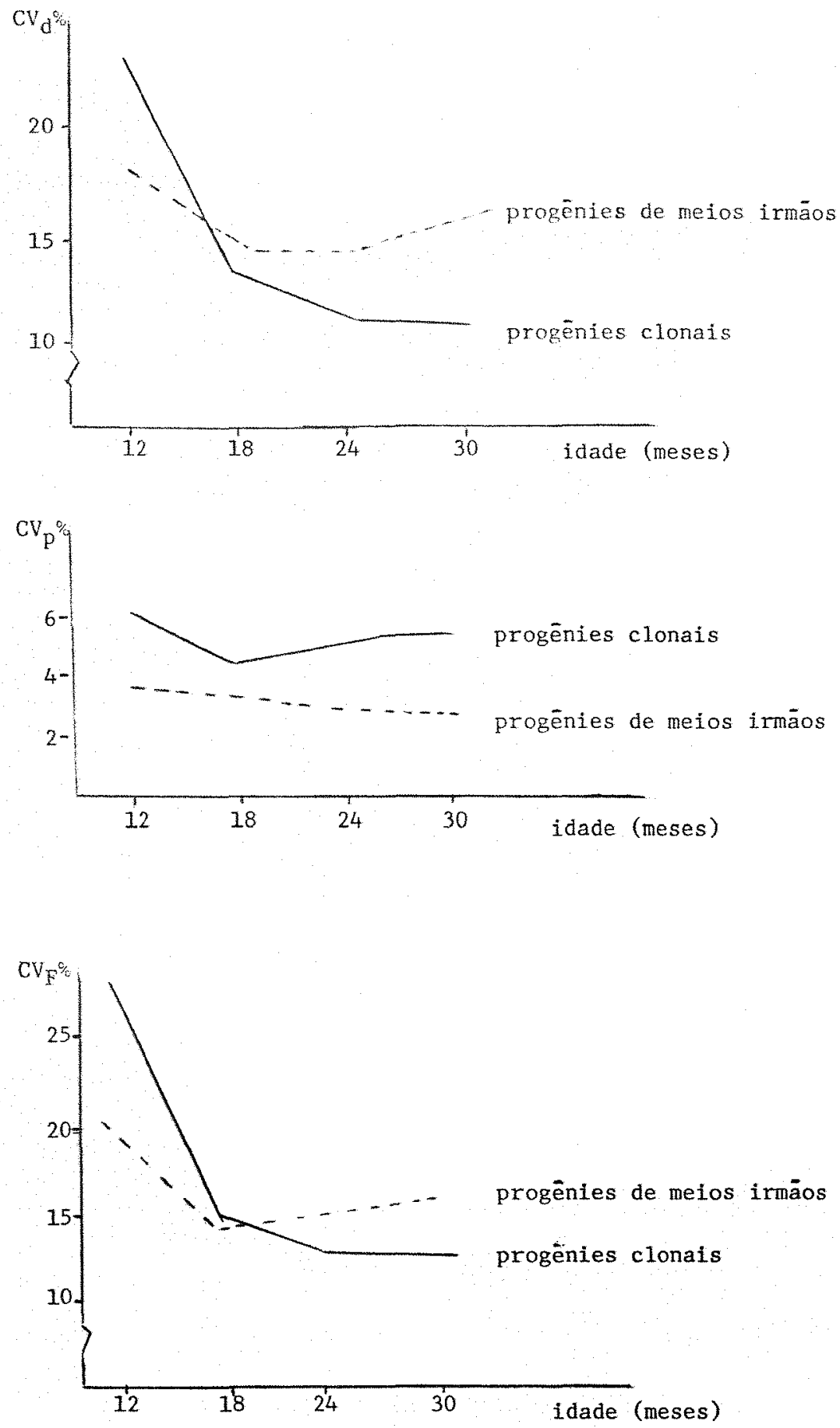

Figura 2. Evoluçäo dos coeficientes de variação da variäncia dentro $\left(\mathrm{CV}_{\mathrm{d}} \%\right)$, variāncia genética entre progēnies $\left(\mathrm{CV}_{\mathrm{p}} \%\right)$ e variāncia fenotípica $\left(\mathrm{CV}_{\mathrm{F}} \%\right)$, para a característica diāmetro (DAP), em progēnies de meios irmāos e clonais. 
4.3.2. Estimativas de herdabilidade

As estimativas de herdabilidade obtidas para as progénies de meios imãos (sentido restrito) e para progênies clonais (sentido amplo), para as características avaliadas são apresentadas na Tabela 22.

Para as estimativas da herdabilidade no sentido restrito, as progēnies estudadas foram consideradas como sendo de meior irmãos e a ocorréncia de endogamia desprezîvel, conforme preconizado por VENCOVSKY (1969).

Os valores de coeficientes de herdabilidade tanto no sentido restrito como no sentido amplo variaram nas diferentes idades, características e métodos de propagação, mostrando que a herdabilidade não é uma magnitude fixa e depende tanto da população como do meio ambiente, conforme relatado por DITLEVISEN (1980).

A característica volume cilindrico apresentou valores maiores para os trēs tipos de herdabilidade, tanto para matrizes selecionadas como para testemunhas. Estes dados não estão coerentes com os resultados encontrados em literatura, onde de uma maneira geral a característica volume cilindrico é considerada de baixa herdabilidade, como foi constatado por PATINO-VALERA (1986), em Eucalyptus saligna e MORAES (1987) em Eucalyptus grandis. 
Tabela 22. Estimativas de coeficientes de herdabilidade ao nivel de plantas individuais ( $h^{2}$ individuais), ao nivel de médias de familias ( $h^{2}$ médias) e ao nivel de plantas dentro de familias $\left(h^{2}\right.$ dentro), no sentido restrito para progénies de meios irmãos e no sentido amplo para progénies clonais

\begin{tabular}{|c|c|c|c|c|c|c|}
\hline \multirow{2}{*}{$\begin{array}{l}\text { Caracte- } \\
\text { ristica }\end{array}$} & \multirow[b]{2}{*}{ herdabil. } & \multirow[b]{2}{*}{ Idade } & \multicolumn{2}{|c|}{ Progēnies de meios irmãos } & \multicolumn{2}{|c|}{ Progēnies clonais } \\
\hline & & & $\begin{array}{l}\text { matrizes } \\
\text { selecio- } \\
\text { nadas }\end{array}$ & $\begin{array}{l}\text { teste- } \\
\text { munhas }\end{array}$ & $\begin{array}{c}\text { matrizes } \\
\text { selecio- } \\
\text { nadas }\end{array}$ & $\begin{array}{l}\text { teste- } \\
\text { munhas }\end{array}$ \\
\hline \multirow{3}{*}{ Al tura } & $h^{2}$ indiv. & $\begin{array}{l}12 \\
18 \\
24 \\
30\end{array}$ & $\begin{array}{l}0,27 \\
0,10 \\
0,28 \\
0,27\end{array}$ & $\begin{array}{l}0,22 \\
0,12 \\
0,09 \\
0,08\end{array}$ & $\begin{array}{l}0,14 \\
0,15 \\
0,18 \\
0,28\end{array}$ & $\begin{array}{l}0,23 \\
0,25 \\
0,28 \\
0,28\end{array}$ \\
\hline & $h^{2}$ médias & $\begin{array}{l}12 \\
18 \\
24 \\
30\end{array}$ & $\begin{array}{l}0,61 \\
0,43 \\
0,64 \\
0,67\end{array}$ & $\begin{array}{l}0,48 \\
0,37 \\
0,36 \\
0,36\end{array}$ & $\begin{array}{l}0,67 \\
0,64 \\
0,72 \\
0,82\end{array}$ & $\begin{array}{l}0,76 \\
0,78 \\
0,82 \\
0,83\end{array}$ \\
\hline & $h^{2}$ dentro & $\begin{array}{l}12 \\
18 \\
24 \\
30\end{array}$ & $\begin{array}{l}0,23 \\
0,08 \\
0,23 \\
0,22\end{array}$ & $\begin{array}{l}0,19 \\
0,09 \\
0,07 \\
0,06\end{array}$ & & \\
\hline \multirow{3}{*}{ DAP } & $h^{2}$ indiv. & $\begin{array}{l}12 \\
18 \\
24 \\
30\end{array}$ & $\begin{array}{l}0,27 \\
0,31 \\
0,26 \\
0,22\end{array}$ & $\begin{array}{l}0,14 \\
0,19 \\
0,25 \\
0,29\end{array}$ & $\begin{array}{l}0,10 \\
0,13 \\
0,23 \\
0,26\end{array}$ & $\begin{array}{l}0,16 \\
0,16 \\
0,23 \\
0,22\end{array}$ \\
\hline & $h^{2}$ médias & $\begin{array}{l}12 \\
18 \\
24 \\
30\end{array}$ & $\begin{array}{l}0,64 \\
0,75 \\
0,71 \\
0,71\end{array}$ & $\begin{array}{l}0,42 \\
0,62 \\
0,64 \\
0,70\end{array}$ & $\begin{array}{l}0,58 \\
0,68 \\
0,81 \\
0,83\end{array}$ & $\begin{array}{l}0,68 \\
0,72 \\
0,78 \\
0,79\end{array}$ \\
\hline & $h^{2}$ dentro & $\begin{array}{l}12 \\
18 \\
24 \\
30\end{array}$ & $\begin{array}{l}0,23 \\
0,24 \\
0,20 \\
0,17\end{array}$ & $\begin{array}{l}0,12 \\
0,15 \\
0,20 \\
0,23\end{array}$ & & \\
\hline \multirow{3}{*}{ Vol.cil. } & $h^{2}$ indiv. & $\begin{array}{l}24 \\
30\end{array}$ & $\begin{array}{l}0,34 \\
0,29\end{array}$ & $\begin{array}{l}0,26 \\
0,32\end{array}$ & $\begin{array}{l}0,30 \\
0,36\end{array}$ & $\begin{array}{l}0,25 \\
0,26\end{array}$ \\
\hline & $h^{2}$ médias & $\begin{array}{l}24 \\
30\end{array}$ & $\begin{array}{l}0,76 \\
0,70\end{array}$ & $\begin{array}{l}0,68 \\
0,72\end{array}$ & $\begin{array}{l}0,86 \\
0,89\end{array}$ & $\begin{array}{l}0,79 \\
0,82\end{array}$ \\
\hline & $h^{2}$ dentro & $\begin{array}{l}24 \\
30\end{array}$ & $\begin{array}{l}0,27 \\
0,24\end{array}$ & $\begin{array}{l}0,21 \\
0,26\end{array}$ & & \\
\hline
\end{tabular}


Uma caracteristica com alta herdabilidade, segundo FALCONER (1981), pode ser melhorada através de seleção massal, enquanto que para caracteristicas de baixa herdabilidade a seleção por famîlias seria muito mais eficiente. Os coeficientes de herdabilidade ao nivel de médias de familias, foram consideravelmente mais altos do que ao nivel de plantas individuais e dentro de familias. Segundo Kriebel et alii (1972) e Cotteri11 \& Zed (1980), citados por MORAES (1987), estes resultados indicam que a seleção com base em famîtias deve ser mais efetiva que a dentro de familitias.

As tendencias de herdabilidade ao nivel de plantas individuais variaram para cada característica e para cada idade analisada. Para a característica altura, observa-se diferentes padrões nos coeficientes de herdabilidade no sentido restrito e no sentido amplo. No sentido restrito (progénies de meios irmãos) houve um decrëscimo da herdabilidade aos 18 meses, tornando a crescer aos 24 meses de idade. Contudo, as matrizes selecionadas apresentaram sempre maiores valores de coeficientes de herdabilidade em relação às testemunhas, sendo que essas diferenças continuaram aumentando ligeiramente com a idade.

A herdabilidade no sentido amplo (progēnies clonais) para altura apresentou uma leve tendēncia de aumento dos valores com a idade, tanto nas matrizes selecionadas como nas testemunhas. Entretanto, diferentemente das progēnies de meios irmãos, as testemunhas apresentaram sempre valores maiores de herdabilidade no sentido amplo em relação às matrizes selecionadas, sendo que essa diferença tendeu a diminuir aos 30 meses de idade. 
Para a caracterîstica diâmetro (DAP), a herdabilidade individual no sentido restrito (progénies de meios irmãos) apresentou uma tendéncia de diminuição somente aos 18 meses de idade nas matrizes selecionadas, enquanto que nas testemunhas a herdabilidade continuou a aumentar com a idade. Aos 30 meses, as testemunhas apresentaram herdabilidade maior do que as matrizes selecionadas. Ainda para a caracteristica DAP, a herdabilidade individual no sentido amplo (progénies clonais) demonstrou uma tendéncia de crescimento com a idade nas matrizes selecionadas. Nas testemunhas clonais a herdabilidade no sentido amplo aumentou atē os 24 meses e decresceu entre 24 e 30 meses.

A herdabilidade individual no sentido restrito para volume cilindrico mostrou um decrēscimo nas matrizes selecionadas, enquanto que nas testemunhas houve um crescimento nos valores entre 24 e 30 meses. Já a herdabilidade individual no sentido amplo para volume cilindrico mostrou que houve um crescimento nos valores, tanto para matrizes selecionadas como para testemunhas.

Estas tendências de aumento dos valores de coeficientes de herdabilidade com a idade não estão coerentes com o que foi constatado peIos vārios autores em Eucalyptus, como KAGEYAMA (1983) e PATINO-VALERA (1986), que verificaram tendéncias de diminuição com a idade.

A diminuição dos valores dos coeficientes de herdabilidade no sentido restrito com a idade, segundo KAGEYAMA (1983), se deve à diminuição de variāncia genética ou ao incremento de variação fenotipica. 0 mesmo autor salienta que o decréscimo do coeficiente de herdabilidade poderia ser explicado pelo decréscimo mostrado pelo coeficiente de variação 
genética. MORI (1987) comenta que caracteristicas com diferentes herdabili dades possuem comportamento diferenciado em relação à competição. 0 mesmo autor cita que valores de herdabilidade encontrados por PATINO-VALERA (1986) foram decrescentes para altura, DAP e volume cilindrico, inversamente proporcional aos efeitos competicionais. Segundo SAKAI \& MUKAIDE (1986), os efeitos da competição ambiental podem aumentar substancialmente a variāncia total em povoamentos de mistura de genótipos em relação aos povoamentos puros, exercendo influências nas estimativas de herdabilidade.

Em progênies clonais houve um aumento da variância entre progēnies, enquanto que a variāncia fenotipica mostrou um aumento menor, uma vez que a variāncia dentro foi menor. Este fato poderia explicar o au mento do valor da herdabilidade com a idade.

Para a característica altura, os valores de herdabilidade ao nivel de mëdias mostraram tendēncias semelhantes aos de herdabilidades individuais. Em progēnies de meios imãos, a herdabilidade média nas matrizes selecionadas decresceu aos 18 meses, tornando a aumentar até os 30 meses de idade. As matrizes selecionadas apresentaram sempre maiores valores de herdabilidade mëdia en relação às testemunhas.

Em progēnies clonais, a herdabilidade à nīvel de mēdias para altura mostrou, nas matrizes selecionadas, um ligeiro decréscimo aos 18 meses, tornando a crescer aos 24 meses de idade enquanto que nas testemunhas mostrou uma nîtida tendēncia de aumento com a idade. As testemunhas sempre apresentaram maiores coeficientes de herdabilidade média em relação às matrizes selecionadas, sendo q̨ue essa diferença tendeu a diminuir aos 30 meses de idade. 
Para a caracteristica DAP, a herdabilidade média em progênies de meios irmãos mostrou uma tendēncia de decréscimo apōs 18 meses nas matrizes selecionadas, enquanto que nas testemunhas mostrou nitida tendēncia de aumento, atingindo o maior valor de herdabilidade média aos 30 meses. Em progēnies clonais, a herdabilidade ao nivel de médias de famîlias para DAP mostrou uma leve tendência de crescimento até os 30 meses de idade, tanto nas matrizes selecionadas como nas testemunhas.

Para a caracteristica volume cilindrico, a herdabilidade média para as progēnies de meios irmãos mostrou valores prōximos entre 24 e 30 meses de idade. Houve um ligeiro decréscimo para as matrizes selecionadas e um pequeno aumento para as testemunhas. Jā para as progēnies clonais, a herdabilidade média mostrou um ligeiro crescimento tanto para matrizes selecionadas como para testemunhas.

As estimativas de herdabilidade ao nīvel de plantas dentro de familias ( $h^{2}$ dentro) foram obtidas somente em progēnies de meior irmãos. Em progēnies clonais, a variabilidade genética dentro de clones é nula, existindo apenas o efeito ambiental.

0 coeficiente de herdabil idade dentro para progēnies de meios irmãos não mostrou nenhuma tendēncia nos valores com a idade, nas très caracterîsticas estudadas.

0 coeficiente de herdabilidade para progēnies de meios irmãos, para as trēs caracterīsticas estudadas, foram menores que para progēnies clonais aos 30 meses de idade. Essas diferenças são mostradas na Tabela 23. 


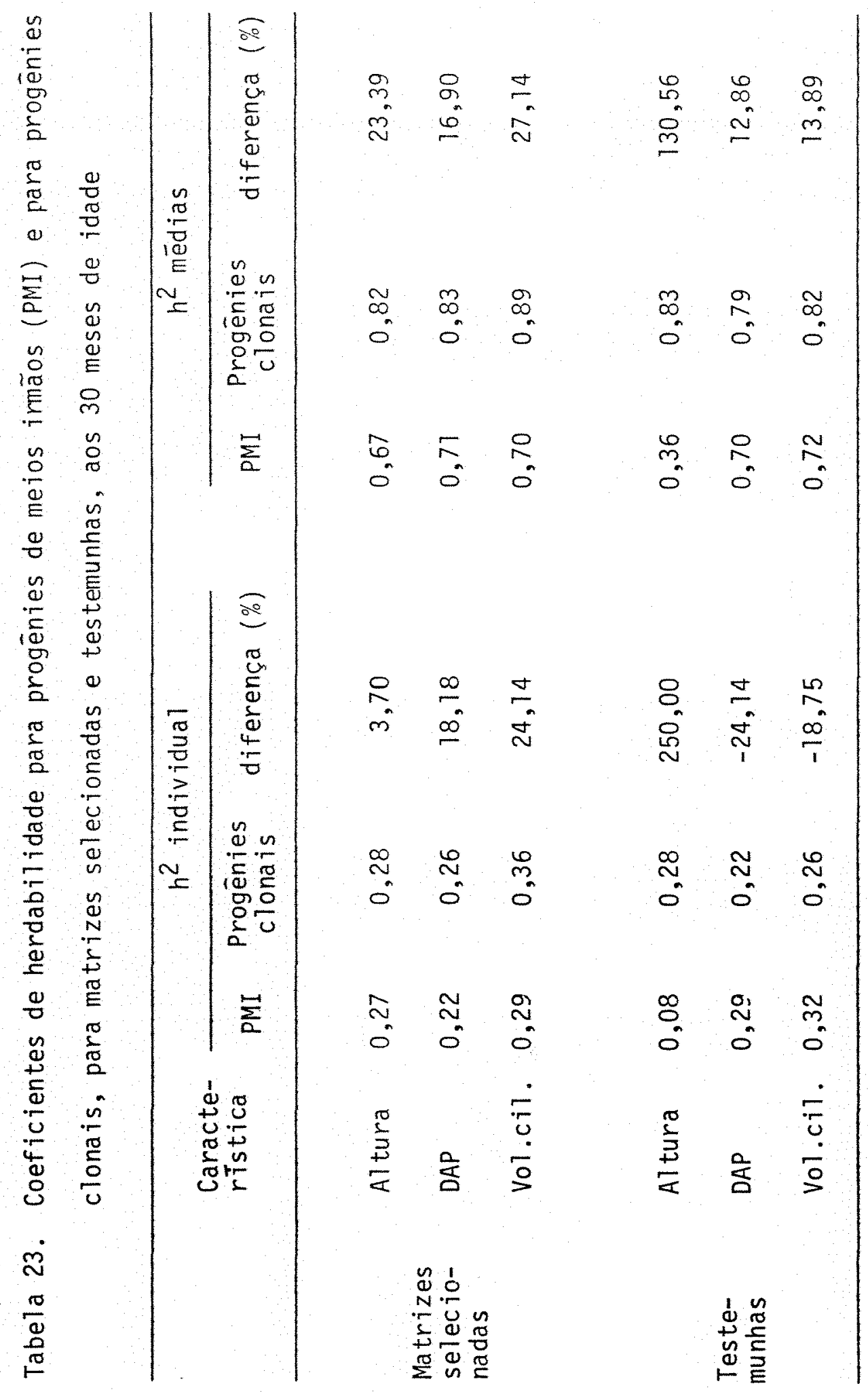


Os coeficientes de herdabilidade individual no sentido amplo para matrizes selecionadas foram maiores que no sentido restrito. Essas diferenças foram de $3,70 \%, 18,18 \%$ e $24,14 \%$, respectivamente para as caracteristicas altura, DA.P e volume cilindrico. Para as testemunhas as diferenças entre os coeficientes de herdabilidade no sentido amplo e no sentido restrito foram de $250,00 \%,-24,14 \%$ e $-18,75 \%$, respectivamente para altura, DAP e volume cilindrico.

Os coeficientes de herdabilidade ao nīvel de médias de famîlias em progénies de meios irmãos tambēm foram menores que em progénies clonais, aos 30 meses de idade. As diferenças nas matrizes selecionadas foram de $23,39 \%, 16,90 \%$ e $27,14 \%$, respectivamente para altura, DAP e volume cilindrico enquanto que nas testemunhas essas diferenças foram de $130,56 \%, 12,86 \%$ e $13,89 \%$, para altura, DAP e volume cilindrico respectivamente. Poucos estudos têm sido feitos com o objetivo de comparar a herdabilidade no sentido amplo e no sentido restrito. TODA (1972) encontrou valores de herdabilidades majores no sentido restrito do que no sentido amplo, para diversas caracteristicas em Criptomeria japonica. Por outro lado, Stern (1962), citado por HATTEMER (1963), encontrou valores de herdabilidades ligeiramente maiores no sentido amplo em relação ao de sentido restrito para as características altura e resistēncia à doença em Betula verrucosa. Resultado semelhante tambëm foi verificado por Bingham (1960), citado por HATTEMER (1963) para resistēncia à doenças em pinus monticola.

As comparações dos coeficientes de herdabilidade entre as matrizes selecionadas e as testemunhas, aos 30 meses de idade estão expressos na Tabela 24. 


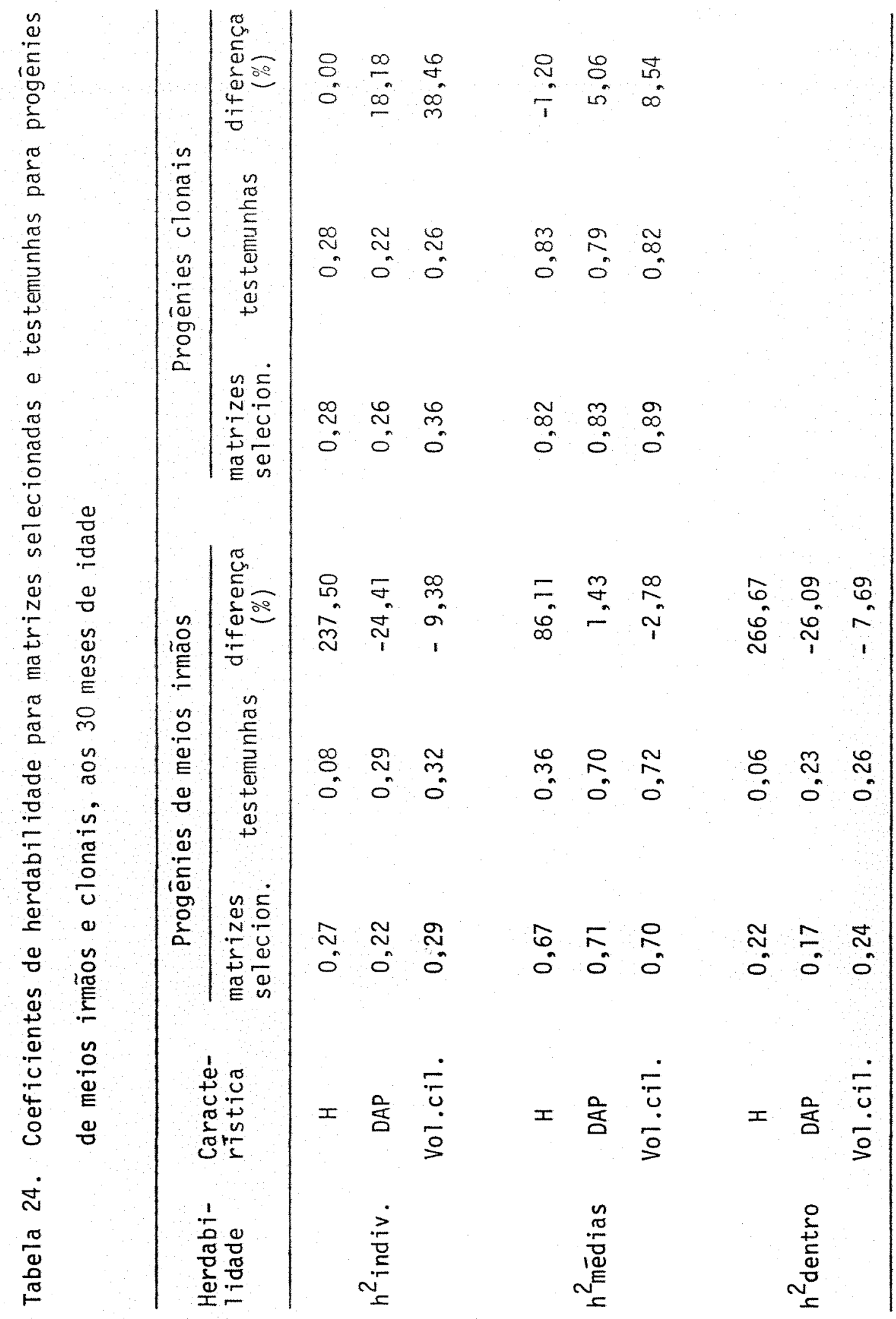


Para a caracteristica altura nas progénies de meios irmãos, os trēs tipos de herdabilidade nas matrizes selecionadas foram mais altos que nas testemunhas, enquanto que no sentido amplo foram menores. Já para as caracteristicas DAP e volume cilindrico e para progênies de meios irmãos, os trēs tipos de herdabilidade apresentaram valores menores nas matrizes selecionadas em relação às testemunhas, enquanto que para progēnies clonais foram mais altos nas matrizes selecionadas.

As diferenças de herdabilidade ao nīvel de plantas individuais entre matrizes selecionadas e testemunhas, no sentido restrito foram de $237,50 \%,-24,41 \%$ e $-9,38 \%$, respectivamente para altura, DAP e volume cilindrico, enquanto que no sentido amplo, foram de $0,00 \%, 18,18 \%$ e $38,46 \%$ respectivamente para altura, DAP e volume cilindrico. Para a herdabilidade ao nível de média de famīlias em progēnies de meios irmãos, as diferenças entre as matrizes selecionadas e as testemunhas foram de $86,11 \%, 1,43 \%$ e $-2,78 \%$, respectivamente para altura, DAP e volume cilindrico. Para as progénies clonais as diferenças foram de $-1,20 \%, \quad 5,06 \%$ e $8,54 \%$, respectivamente para altura, DAP e volume cilindrico.

0 uso da estimativa da variância dentro de parcelas $\left(\sigma^{2} d\right)$ para estimar a variāncia devida ao erro entre parcelas $\left(\sigma^{2} e\right)$, e desta para estimar a variāncia entre progēnies $\left(\sigma^{2} p\right)$, tem consequéncias sobre a estimativa de herdabilidade. Somente após muitas estimativas pode-se ter valores mais confiāveis de herdabilidade para cada material genético e método de propagação. 
4.3.3. Estimativa de ganho genëtico com seleção entre e dentro de progênies para as características altura, DAP e volume ciTindrico

As estimativas de ganhos genéticos com a seleção entre e dentro de progênies de meios irmãos e entre progénies clonais, para as caracteristicas estudadas, aos 30 meses de idade, estão apresentadas na Tabela 25.

Em progēnies de meios irmãos a seleção entre e dentro de progénies visa a transformação do teste em "pomar de sementes por mudas" com a eliminação de indivíduos e familitias inferiores. Neste caso o ganho genētico estimado em porcentagem da média das progēnies é para a propagação atravēs de sementes.

Em progēnies clonais, a seleção dentro de progēnies não foi considerada uma vez que são plantas geneticamente iguais. 0 ganho genético com a seleção entre clones significa o ganho a ser obtido quando os melhores clones forem novamente propagados vegetativamente. Deve-se lembrar que o ganho genētico esperado è expresso em porcentagem sobre a média do ensaio. A comparação do ganho esperado entre os métodos de propaga ção nos diferentes materiais genéticos não é vālida sem considerar o efeito fisiológico das mudas nas respectivas médias.

Para o cāiculo utilizou-se uma intensidade de seleção de $20 \%$ entre e $10 \%$ dentro de progēnies de meios irmãos para todas as características. Para progénies clona is utilizou-se tambēm $20 \%$ de seleção entre clones, embora seja possivel aplicar maior intensidade de seleção, o que 


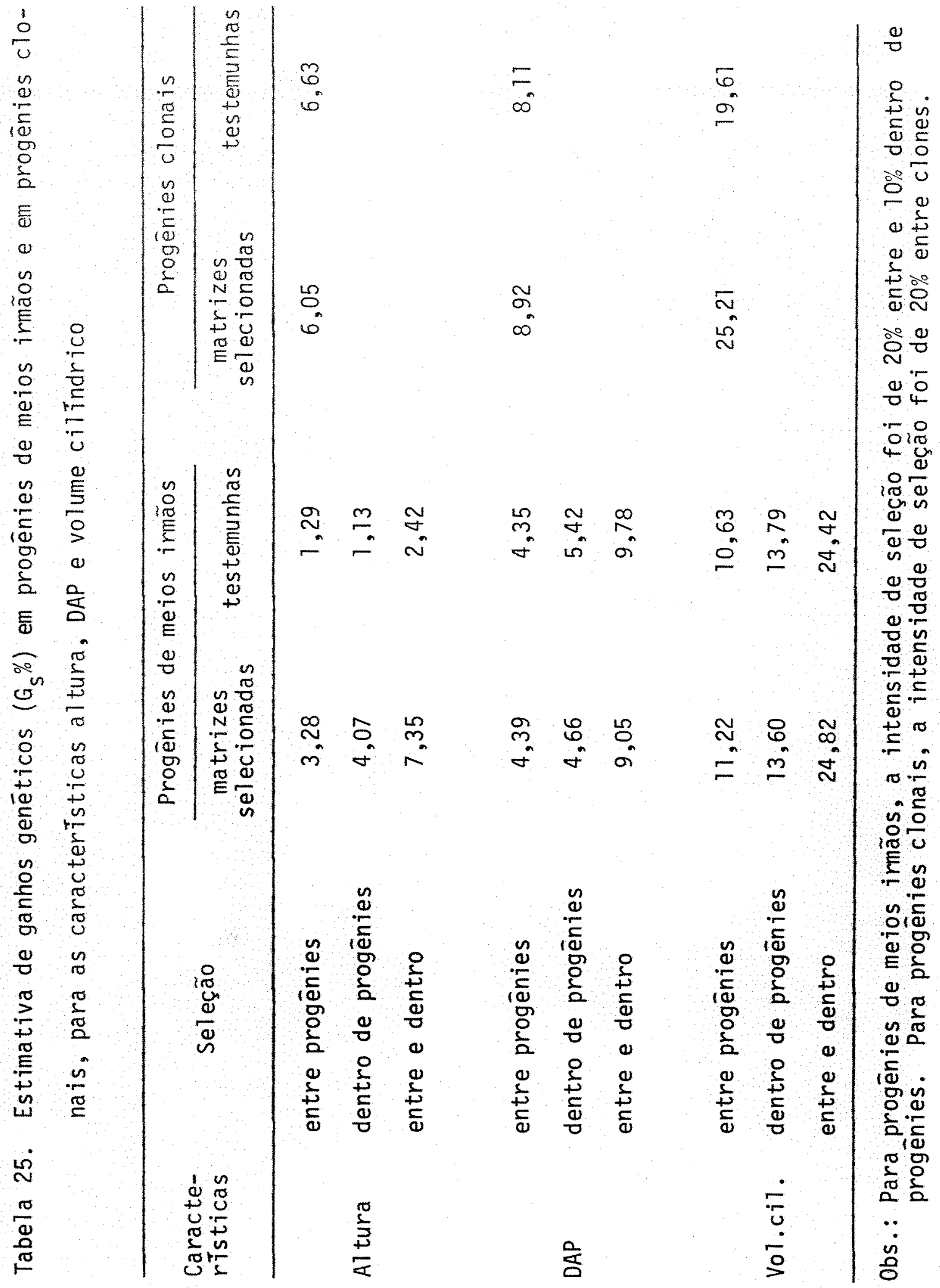


poderia proporcionar maiores ganhos. Portanto, para efeito de comparação entre progénies de meios irmãos e progénies clonais, o major ou menor ganho foi em função da herdabilidade e do coeficiente de variação fenotipica. Os ganhos esperados foram obtidos aplicando-se a mesma intensidade de seleção, independentemente, para todas as caracterỉsticas.

Para progénies de meios irmãos, a seleção dentro de progènies proporcionou maiores ganhos que a seleção entre progénies para todas as caracteristicas. Este resultado está coerente com o que foi verificado por MORAES (1987). Somando-se os ganhos entre e dentro de progénies, - maior ganho foi verificado para a caracteristica volume cilindrico, seguido do DAP e altura. Esse resultado pode ser explicado pela maior herdabilidade obtida para o volume cilindrico e pelo maior coeficiente de variação fenotîpica.

Com relação ao material genético em progénies de meios irmãos verificou-se, para a característica altura, maior ganho nas matrizes selecionadas $(7,35 \%)$, comparadas com as testemunhas $(2,42 \%)$. Jā para a caracteristica DAP o ganho foi ligeiramente superior nas testemunhas $(9,78 \%$ contra $9,05 \%)$, enquanto que para a caracterîstica volume cilindrico os ganhos esperados foram semelhantes.

Para as progēnies clonais, os maiores ganhos foram verificados também para volume cilindrico seguido do DAP e altura. Com relação ao material genético em progénies clonais, os ganhos entre as matrizes selecionadas e testemunhas foram diferentes daqueles verificados em progènies de meios irmãos. Para a característica altura e DAP verificou-se va.Tores de ganho esperado ligeiramente superiores para testemunhas, enquanto 
que para volume cilindrico o ganho foi maior para matrizes selecionadas. Esses resultados seguem as mesmas variações observadas nos coeficientes de herdabilidade.

Os ganhos genēticos para progēnies de meios irmãos referemse à propagação por semente, enquanto que para progènies clonais referemse à propagação vegetativa. O menor ganho obtido para progênies de meios imãos para seleção entre famîlias pode ser compensado com a seleção dentro de famîlias, o que não acontece em progēnies clonais. Assim quando se faz seleção entre e dentro de progēnies de meios irmãos, o ganho se tor na próximo ao valor na seleção entre clones. Esses resultados foram obtidos quando se aplicaram as mesmas intensidades de seleção nos dois métodos de propagação. 0 aumento da intensidade na seleção entre clones poderā elevar ainda mais os ganhos, mas os riscos de infestação de pragas e doenças em plantações constituídas por um nümero limitado de clones tambēm poderā aumentar. A propagação vegetativa proporciona um ganho räpido comparado à propagação sexuada atravēs de seleção de melhores ārvores, segundo ZOBEL et alii (1983), e a perspectiva mais atraente é o uso total dos efei tos dos genes não aditivos, o qual não é possível obter na propagação por sementes, conforme colocado por BURDON (1982).

Os resultados obtidos com a seleção dos melhores clones demonstram que num programa de propagação vegetativa por estaquia torna-se necessāria a implantação de testes clonais, para se ter um ganho māximo. A simples seleção fenotīpica das matrizes e a sua propagação por estaquia, produziu menor crescimento médio que a propagação por semente. Porēm os 
ganhos esperados após a seleção dos melhores clones pode ser maior na propagação vegetativa que na propagação por semente. Neste caso, è importante considerar o tempo envolvido para a obtenção de ganho, jā que dependendo do mētodo, pode se demandar mais ou menos tempo para a utilização do material melhorado. No caso de Eucatyptus grandis que é bastante precoce na frutificação, tanto a produção de sementes melhoradas em pomar de sementes por mudas, ass im como a produção de estacas dos melhores clones levaria o mesmo tempo. 
5. CONCLUSOES

Os resultados apresentados e discutidos neste trabalho permitiram as seguintes conclusões:

- Nas anālises individuais, foram detectadas variações genēticas entre progènies para as caracteristicas Altura, DAP e volume cilindrico, tanto entre progênies de meios irmãos como entre progênies clonais.

- As progénies de meios irmãos apresentaram melhor crescimento em relação às progēnies clonais atē 30 meses de idade, tanto para matrizes selecionadas como para testemunhas, com uma tendēncia para diminuição dessa diferença com o decorrer da idade.

- As matrizes selecionadas apresentaram maior crescimento em relação às testemunhas sem seleção, sendo esta diferença maior na propagação por estaquia.

- Nas anālises conjuntas para métodos de propagação foram detectadas variações genéticas entre progēnies para todas as características, tanto para matrizes selecionadas como para testemunhas. Os efeitos 
do método de propagaçăo foram expressivos, nas caracteristicas avaliadas, assim como a interação progénies $x$ métodos de propagação.

- Algumas matrizes apresentaram um melhor desenvolvimento quando propagadas por sementes, enquanto outras foram melhores quando propagadas por estaquia; ainda, algumas mostraram o mesmo comportamento em ambos os métodos de propagação, mostrando a necessidade de utilização de materiais especificos nos programas de melhoramento sexuado ou assexuado.

- Apesar de apresentar, em média, um desenvolvimento inferior à propagação por sementes, as estacas mostraram alguns clones excepciona is com crescimento inclusive superior a qualquer progênie de meios irmãos.

- Os clones apresentaram menores valores de variāncia dentro de progēnies $\left(\sigma^{2} d\right)$ en relação às progēnies de meios irmãos, enquanto para a variāncia entre progēnies $\left(\sigma^{2} p\right)$ foram detectados menores valores em progēnies de meios irmãos em comparação com as progēnies clonais.

- As progēnies clonais mostraram uma tendēncia de diminuição com a idade dos valores de coeficientes de variação dentro de parcelas, nas trēs caracterīsticas estudadas.

- Os coeficientes de herdabilidades foram, no geral, maiores no sentido amplo que no sentido restrito, tanto ao nivel de plantas individuais como de médias de famīilias. Os coeficientes de herdabilidade mostraram diferentes padrões de variação com a idade para cada caracteristica estudada, método de propagação e material genético utilizado. 
- Os ganhos genéticos estimados para a seleção entre progènies (intensidade de seleção de $20 \%$ foram superiores nas progēnies clonais em relação às progēnies de polinização livre; esses ganhos foram compensados quando se acrescentou a seleção dentro de progēnies (intensidade de seleção de $10 \%$ ) no material propagado por semente. 
LITERATURA CITADA

ASSIS, T.F. et alii. Teste de Progēnies de Eucalyptus grandis Hill Ex. Maiden. Silvicultura, São Paulo 8(28):165-167, 1982a.

ASSIS, T.F. et alii. Teste de Progēnies de Eucalyptus paniculata SM. Silvicultura, São Paulo 8(28):160-161, $1982 b$.

ASSIS, T.F. et alii. Ensaio de Progēnies de Eucalyptus cloesiana F.Meul1. Silvicultura, São Paulo 8(28):158-159, 1982c.

BERTOLOTI, G. Comportamento genético e nutricional de Eucalyptus grandis W. Hill ex. Maiden em solo podzól ico vermelho escuro e areia quartzosa à]ica em Lençōis Paulista, S.P., Piracicaba, 1986. 80p. (Mestrado, Escola Superior de Agricultura "Luiz de Queiroz"/USP).

BRITO, J.0.; BARRICHELO, L.E.E. \& FERREIRA, M. O melhoramento da madeira frente à produção de celulose e papel. Boletim Informativo IPEF, Piracicaba $6(19): 95-115,1978$. 
BURDON, R.D. Genetic correlation as a concept for studing genotypeenvironment interaction in forest tree breeding. Sitvae Genetica, Frankfurt, $26(5 / 6): 168-175,1977$.

BURDON, R.D. The role and optimal place of vegetative propagation in tree breeding strategies - In: IUFRO JOINT MEETING OF WORKING PARTIES ON GENETICS ABOUT BREEDING STRATEGIES INCLUDING MULTICLONAL VARIETIES. Escherode, Proceedings p.66-83, 1982.

BURDON, R.D. \& SHELBOURNE, C.J.A. The use of vegetative propagules for obtaining genetic information. In: WORKSHOP ON VEGETATIVE PROPAGATION OF FOREST TREES. Rotorua, 1984. 9p.

BURLEY, J. et alii. Progeny test designs for Pinus patula in Rhodesia, Silvae Genetica, Frankfurt, 15:116-173, 1986.

CAMPINHOS JR. F. Produção de propāgulos vegetativos (por enraizamento de estacas) de Eucalyptus spp em viveiro. Aracruz, 1982. 11p. (Separata).

CHAPERON, $\mathrm{H}$. Influence of propagation by cuttings on the breeding strategy of forest trees: In: JOINT MEETING OF IUFRO WORKING PARTIES ON PROVENANCE AND GENETIC IMPROVEMENT STRATEGIES IN TROPICAL FOREST TREES. Mutare, Zimbabue, 1984, 13p. (Separata).

CHAPERON, H. \& QUILLET, G. Results of studies on the use of Eucalyptus cutting in Congo-Bragaville. In: JOINT IUFRO WORKSHOP, Proceedings, Brisbane, 1977. p.1040-59. 
CHAVES, R.; KAGEYAMA, P.Y. \& COUTO, H.T.Z. Estimativas de variação genética e da herdabilidade para florescimento de Pinus caribaea var. honawensis Barr. e Colf. e en Pinus oocarpa Schiede. IPEE, Piracicaba $(25): 15-23,1983$.

COCHRAN, W.G. \& COX, G.M. Diseños experimentales - 7 à ed. México, Editorial Tritlas, 1983. 661p.

DITLEVISEN, B. Cenetica cuantitativa: principios generales y su aplicaciōn pratica en la mejora de ārbores forestales. In: FAO/DANIDA, MEJORA GENETICA DE LOS ARBORES FORESTALES. Roma, 1980. p.177-188.

ELDRIDGE, K.G. Genetic improvement of Eucalyptus. In: THIRD WORLD CONSULTATION ON TREE BREEDING. vol. 2, Camberra, 1977. p.545-559.

FALCONER, D.S. Introdução a genética quantitativa. Viçosa, Universidade Federal de Viçosa, 1981. 279p.

FERREIRA, M. Uma Revolução: 0 melhoramento genētico florestal - métodos sexuados ou assexuados? Silvicultura, São Pau1o, 2(17):35-39, 1980.

FONSECA, S.M. Estimação e interpretação dos componentes de variação total em experimentos de melhoramento florestal. In: Präticas Experimentais em Silvicultura. Piracicaba, IPEF, 1979. p.H1-H2O.

FONSECA, S.M. Variaçōes Fenotipicas e Genēticas em Bracatinga Mimosa scabrelZa Bentham. Piracicaba, 1982. 86p. (Mestrado, Escola Superior de Agricultura "Luiz de Queiroz"/USP). 
FRANKLIN, E.C. Use of cuantitative genetics in planning multiple - trait breeding. In: THIRD WORLD CONSULTATION ON TREE BREEDING. VOT. 2, Camberra, Austrāilia, 1977. p.1149-1156.

FRAMPTON UR., L.J. Field performance of loblolly pine tissue culture plantlets. In: IUFRO CONFERENCE - A JOINT MEETING OF WORKING PARTIES ON BREEDING THEORY, PROGENY TESTING, SEED ORCHARDS. Virginia. Proceedings, 1986. p.547-553.

FAMPTON JR., L.J. \& MACKEAND, S.E. Characterization of the root and shoot systems of young loblolly pine propagules. North Carolina Suplement to the 1987 annual progress report - Special Project on tissue culture. North Carolina State University, 1987. 47p.

HARAHAP, R.M.S. \& SORIANEGARA, I. Heritability of some characters in teak (Teatona grandis L.F.). In: THIRD WORLD CONSULTATION ON TREE BREEDING. Vo1. 2, Camberra, 1977. p.649-657.

HATTEMER, H.H. Estimates of heritability published in forest tree breeding research. In: FAO - WORLD CONSULTATION ON FOREST GENETICS AND TREE IMPROVEMENT. Vo1. 1. Proceedings. Stockolmo, 1963. 16p.

HOWLAND, P. et aliz. The study of clonal variation in Triplochiton scteroxylon K. Schum. as a basis for selection and improvement. In: NIKLES, D.G.; BURLEY, J. \& BARNES, R.D. Editor: Progress and problems of genetic improvement of tropical forest trees. Vol. 2. Univ.0xford, 1978. p.898-904. 
KAGEYAMA, P.Y. MeThoramento genético de Finus spp. Boletim Informativo IEEF. Piracicaba, $4(11): 47-68,1976$.

KAGEYAMA, P.Y. et alii. Variação genētica entre e dentro de progénies de Pinus patuza Schied e Deppe na região de Telémaco Borba, Pr. IPEF, Piracicaba (15):21-39, 1977 .

KAGEYAMA, P.Y. Variação genética em progēnies de uma população de Eucalyptus grandis (Hi11) Maiden. Piracicaba, 1980a. 125p. (Doutorado, Escola Superior de Agricultura "Luiz de Queiroz"/USP).

KAGEYAMA, P.Y. Melhoramento genético de pinheiros tropicais no Brasil. Circuzar Téenica do IPEF. Piracicaba (111):1-17, $1980 \mathrm{~b}$.

KAgEyAMA, P.Y. Endogamia em espécies florestais. Série Técnica IPEF. Piracicaba, 2(8), 1981. 40p.

KAGEYAMA, P.Y. et alii. Variação genética para densidade da madeira em progēnies de Eucalyptus grandis. Silvicultura, São Paulo $8(28): 318-$ $324,1982$.

KAGEYAMA, P.Y. \& VENCOVSKY, R. Variação genētica em progēnies de uma população de Eucalyptus grandis (Hi11) Maiden. IPEF, Piracicaba (24): 9-26, 1983.

KAGEYAMA, P.Y. Seleção precoce a diferentes idades em progēnies de Eucaoyptus grandis (Hi11) Maiden. Piracicaba, 1983. 147p. (Livre Docēncia, Escola Superior de Agricultura "Luiz de Queiroz"/USP). 
KEDHARNATH, S. \& VAKSHAYA, R.K. Estimates of components of variance, heritability and correlations among some growth parameters in Eucalyptus tereticomis. In: THIRD WORLD CONSULTATION ON TREE BREEDING. Vo1.2, Camberra, 1977. p.1667-1676.

KREJCI, L.C.; MARTINS, L.G.C. \& LOURENÇO, P.Y. Desenvolvimento do sistema radicular de Eucalyptus spp sob diferentes condições do solo. III Encontro Tëcnico COPENER, Salvador, 1986, 24p.

LONGMAM, K.A. Conservation and utilization of gene resources by vegetative multiplication of tropical trees. In: BURLEY, J. \& STYLES, B.T. Editor: Tropical Trees - Variation, Breeding and Conservation. London. Academic Press, 1976. p.19-24.

MACKEAND, S.E. \& WEIR, R.J. Tissue culture and forest productivity. Journal of Forestry. 82(4):212-218, 1984.

MORA, A.L. Interação com espaçamentos e locais em clones de Eucalyptus spp no norte do Estado da Bahia. Piracicaba, 1986, 101p. (Mestrado, Escola Superior de Agricultura "Luiz de Queiroz"/USP).

MORAES, M.L.T. Variação Genética da densidade bāsica da madeira em progênies de Eucalyptus grondis Hill ex Maiden e suas relações com as características de crescimento. Piracicaba, 1987, 115p. (Mestrado, Escola Superior de Agricultura "Luiz de Queiroz"/USP). 
MORI, E.S. Efeitos da competição intra-especîfica na seleção de ārvores superiores de Eucalyptus saligna Smith. Piracicaba, 1987, 79p. (Mestrado, Escola Superior de Agricul tura "Luiz de Queiroz"/USP).

MUNISWANI, K.P. Population improvement and hibridization - Teak. In: THIRD WORLD CONSULTATION ON TREE BREEDING, Vol.2. Camberra, 1977. p. 507 .

NAMKOONG, G. Challenging tree breeding theory. In: IUFRO JOINT MEETING OF WORKING PARTIES ON GENETICS ABOUT BREEDING STRATEGIES INCLUDING MULTICLONAL VARIETIES: Escherode. Proceedings, 1982. p.155-161.

NAMKOONG, G. Imbreeding, hybridization and conservation in provenances of tropical trees. In: JOINT MEETING OF IUFRO WORKING PARTIES ON PROVENANCE AND GENETIC IMPROVEMENT STRATEGIES IN TROPICAL FOREST TREES. Mutare, 1984.7p. (Separata).

NOH, E.R. Heritability of some characters in Pinus densiflora S. et Z. In: JOINT SYMPOSIA FOR FOREST TREE BREEDING OF GENETICS SUBJECT GROUP, IUFRO AND SECTION 5, FOREST TREES. Tokyo. Proceedings, 1972. A.7(V): 1-3.

PATERNIANI, E. Genētica e melhoramento das plantas. In: PAVAN, C. \& CUNHA, A.B.da. EZementos de genética, 2ā edição, São Paulo, Ed. Nacional, 1966. p.549-86. 
PATINO-VALERA, F. Variação genética em progēnies de Eucalyptus saligna Smith e sua interação com o espaçamento. Piracicaba, 1986, 211p. (Mes trado, Escola Superior de Agricultura "Luiz de Queiroz"/USP).

PIMENTEL GOMES, F. Curso de Estatīstica Experimental, 11 å edição. Piracicaba. Livraria Nobel, 1985, 430p.

PIRES, I.E. Variabilidade genética em progēnies de uma população de algaroba Prosopis juZiflora (S.W.) D.C. da região de Soledade - Paraiba. Piracicaba, 1984. 94p. (Mestrado, Escola Superior de Agricultura "Luiz de Queiroz"/USP).

PINTO JR. Variabilidade genētica em progēnies de uma população de EucaZyptus urophyzza S.T. Blake da Ilha de Flores - Indonēsia. Piracicaba, 1984. 166p. Mestrado, Escola Superior de Agricultura "Luiz de Queiroz"/USP).

QUIJADA, R.M. Seleccion de arboles forestales. In: FAO-Mejora genetica de los ärbores forestales. Roma, 1980a. p.169-176.

QUIJADA, R.M. Métodos de propagacion vegetativa. In: FAO - Mejora genética de los arbores forestales. Roma, 1980b. p.169-176.

QUIJADA, R.M. Ensaio de progēnies. In: FAO - Mejora genëtica de los arbores forestales. Roma, 1980c. p.224-230. 
RAUTER, R.M. Recent advances in vegetative propagacion including biological and economic consideration and future potencial. In: IUFRo. JOINT MEETING OF WORKING PARTIES ON GENETICS ABOUT BREEDING STRATEGIES INCLUDING MULTICLONAL VARIETIES. Escherode. Proceedings, 1982. p.3357.

ROBINSON, H.F. \& COCKERHAM, C.C. Estimaciōn y significado de los parāmetros genëticos. Fitoteonia Latinoamericana. Caracas, 2(1-2):23-38. 1965.

ROULAND, H. Evaluation of some important caracteristics in clones families and populations: a comparative study. Rotorua, 1973. 17p.

SAKAI, K.I. \& HATAKAYAMA, S. Estimation of genetic parameters in forest tree without raising progeny. Sizvae Genetica. $12(5): 152-157,1963$.

SAKAI, K. \& MUKAIDE, H. Estimation of genetic, environmental, and competitional variances in standing forests. Silvae Genetica, Frankfurt $16(5 / 6): 149-52,1966$.

SHELBOURNE, C.J.A. Predicted genetic improvement from different breeding methods. In: SECOND WORLD CONSULTATION ON FOREST TREE BREEDING. Washington, 1969, p.1014-1029.

SHELBOURNE, C.J.A. \& STONECYPHER, R.W. The intherance of bole straightness in young loblolly pine. Sizvae Genetica Frankfurt, 20:151-156, 1971. 
SQUILLACE, A.E. et aliz. Heritability of juvenile growth rate and expected gain from selection in western white pine. Silvae Genetica, Trankfurt. $16(1): 1-6,1967$.

THULIN, 1.J. Breeding of Pinus radiata through seed improvement and clonal afforestation. In: SECOND WORLD CONSULTATION ON FOREST TREE BREEDING. Washington, 1969. p.1109-1117.

TODA, R. Mass selection and heritability studies in forest tree breeding. In: FAO - PROCEEDINGS OF THE WORLD CONSULTATION OF FOREST GENETICS AND TREE IMPROVEMENT. Stockholmo. v.1, section 2 a $/ 2.11 \mathrm{p}$.

VENCOVSKY, R. Genētica quantitativa. In: KERR, W.E. (cood): MeZhoramento e Genética, São Paulo - Ed. Melhoramentos, 1969. p.17-37.

VENCOVSKY, R. Principios de Genética Quantitativa. Publicação didātica nọ 16. Dep. de Genética, ESALQ/USP. Piracicaba, 1977. 96p.

VENCOVSKY, R. Herança Quantitativa. In: PATERNIANI, E. (cood): Melhoramento e Produgão de mitho no Brasil. Piracicaba, Fundação Cargill, 1978. p.122-201.

WRIGTH, J.W. Mejoramiento genetico de los arbores forestales. Roma. FAO 1984. $436 \mathrm{p}$. 
ZOBEL, B.J. et atii. Selecting and breeding for desirable wood. Tappi Journat. Atlanta, 66(1):70-3, 1983.

ZOBEL, B.J. \& TALBERT, J. Applied Forest Tree Improvement. New York, John Wiley \& Sons, 1984. 505p. 